
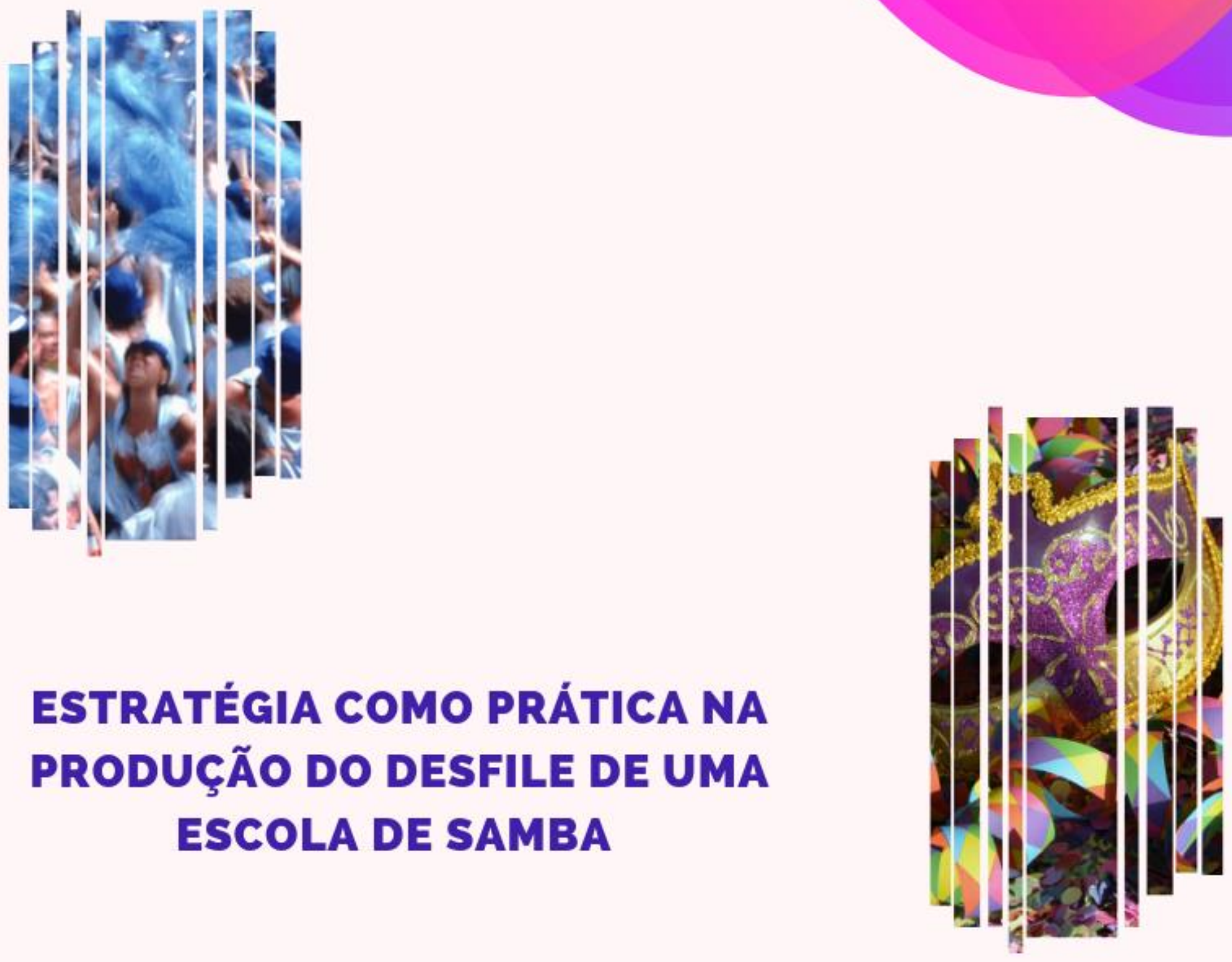

Ana Carolina Júlio da Silva Andrade

\title{
ESTRATÉGIA COMO PRÁTICA NA PRODUÇÃO DO DESFILE DE UMA ESCOLA DE SAMBA
}

Editora Poisson 
Ana Carolina Júlio da Silva Andrade

\section{Estratégia como prática na produção do desfile de uma escola de samba}

1a Edição

Belo Horizonte

Poisson

2019 
Editor Chefe: Dr. Darly Fernando Andrade

\section{Conselho Editorial}

Dr. Antônio Artur de Souza - Universidade Federal de Minas Gerais

Ms. Davilson Eduardo Andrade

Msc. Fabiane dos Santos Toledo

Dr. José Eduardo Ferreira Lopes - Universidade Federal de Uberlândia

Dr. Otaviano Francisco Neves - Pontifícia Universidade Católica de Minas Gerais

Dr. Luiz Cláudio de Lima - Universidade FUMEC

Dr. Nelson Ferreira Filho - Faculdades Kennedy

Ms. Valdiney Alves de Oliveira - Universidade Federal de Uberlândia

Dados Internacionais de Catalogação na Publicação (CIP)

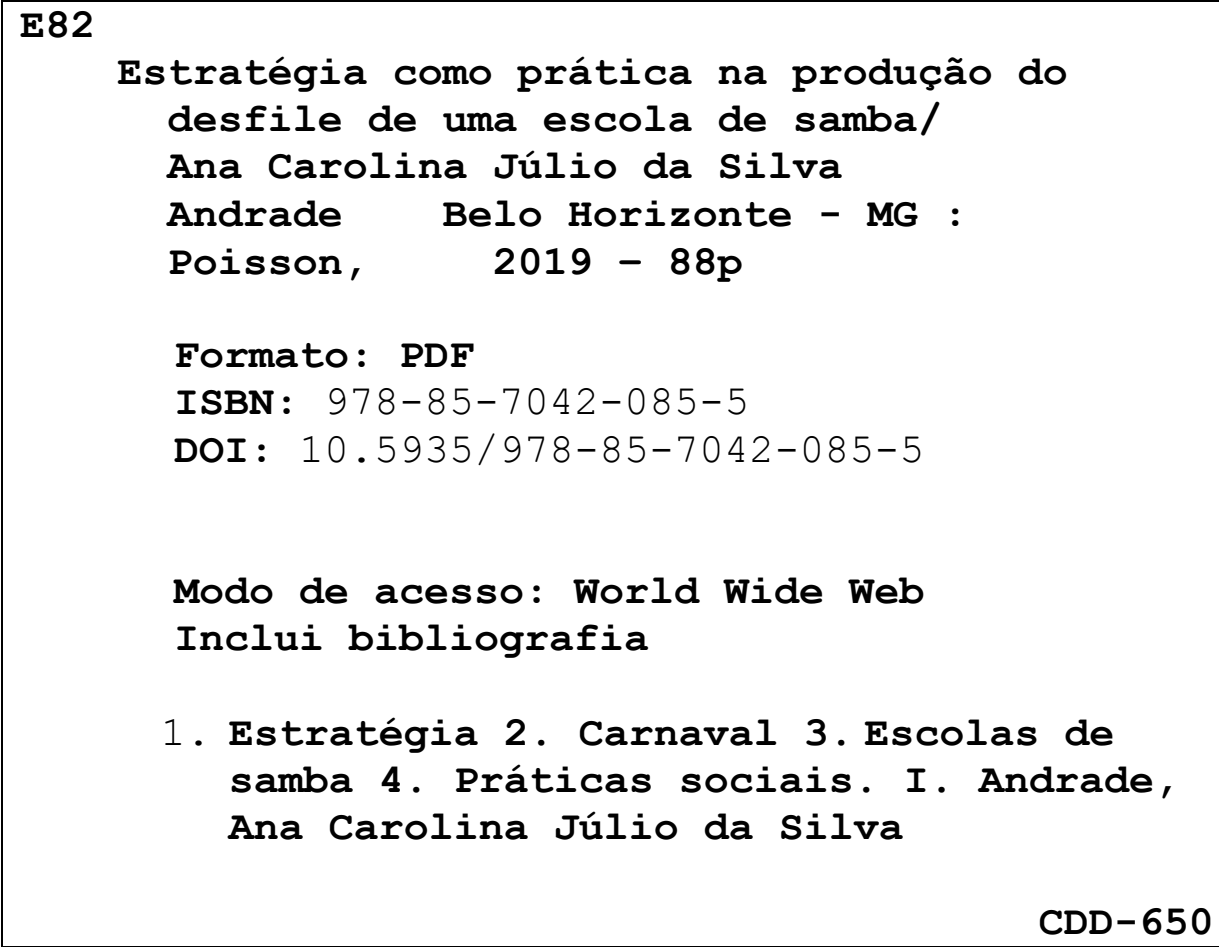

1. Estratégia 2. Carnaval 3. Escolas de samba 4. Práticas sociais. I. Andrade, Ana Carolina Júlio da Silva

CDD -650

O conteúdo dos artigos e seus dados em sua forma, correção e confiabilidade são de responsabilidade exclusiva dos seus respectivos autores.

Baixe outros títulos gratuitamente em www.poisson.com.br 
Aos meus amados avós maternos, Celsa e Evaristo Júlio (in memoriam). 
"E no fim de nossa viagem, voltaremos ao nosso ponto de partida e teremos a impressão de vê-lo pela primeira vez."

T. S. Eliot

"Eu não nasci no samba, mas o samba nasceu em mim Quando eu pisei no terreiro, ouvi o som do pandeiro Me encantei com o tamborim Noite que tem lua cheia Meu coração incendeia Bate mais forte na marcação [...] Quer me fazer feliz, me faz sambar!" Arlindo Cruz; Rogê e Arlindo Neto - “É Corpo, É Alma, É Religião”. 


\section{APRESENTAÇÃO}

O presente trabalho se propõem a analisar a organização das práticas estratégicas da produção do desfile de uma escola de samba. Para compreender esses fenômenos utilizei a epistemologia de Schatzki e a perspectiva da EPS como minha base teórica. A fim de alcançar o objetivo geral, realizei esta pesquisa por meio da triangulação entre observação participante, entrevistas, pesquisa documental e imagens/fotografias. Ressalto que a pesquisa está delimitada à análise da produção do desfile de uma escola de samba de Vitória/ES. Em relação à análise e interpretação dos dados, empreguei o procedimento de análise de conteúdo temático a posteriori.

Os resultados apontam que o fazer estratégia da escola de samba (ilustrado por meio das categorias temáticas que emergiram da análise dos dados) se desdobrou em torno de atividades centrais, envolvendo múltiplos atores, "fazeres" e "dizeres", regras, entendimentos e teleoafetos. No carnaval atual, espera-se que as escolas tenham fantasias e alegorias bonitas, bem feitas, esteticamente bem apresentadas. Afinal, um desfile só é considerado "bom" quando a escola "traz luxo para avenida", impactando visualmente o público e, principalmente, os jurados.

Os integrantes da escola de samba (enquanto praticantes do fazer estratégia) souberam lidar com restrições financeiras e de tempo, tiveram um senso estético refinado, foram criativos, flexíveis, capazes de improvisar, souberam como utilizar materiais mais simples e baratos, ou, até mesmo, de desfiles anteriores, foram hábeis em combinar cores e zelosos com o acabamento de carros e fantasias. Assim, o entendimento, o know-how de cada um desses integrantes em relação a como as práticas carnavalescas acontecem no carnaval capixaba foi fundamental para todo o fazer estratégia da escola, garantindo o vice-campeonato.

A dimensão estética da estratégia, tão marcante no contexto da produção carnavalesca, também é um aspecto que pode ser extrapolado para outros contextos organizacionais. Por meio da estética (de aspectos visuais, por exemplo) é possível mobilizar pessoas. Afinal, o fazer estratégia implica desenvolver uma imagem/projeção para o futuro, o que orienta as ações imediatas. 0 efeito normativo das regras que organizam a produção carnavalesca também permeou o fazer estratégia da escola de samba em análise. As regras eram os quesitos de julgamento do desfile carnavalesco e "Jogar as regras do jogo" foi uma das estratégias adotadas durante a produção do desfile. As teleoafetividades também organizaram, de forma marcante, o fazer estratégia da escola.

O grande objetivo do carnaval de 2014/2015 foi honrar o pavilhão e a memória do presidente da escola. Esse era o desejo de cada integrante e/ou folião que considerava a agremiação sua "escola do coração". Diante disso, considero que os objetivos de uma organização estão para além de seus resultados, orientação, sobrevivência ou vantagem competitiva; podendo coexistir com os afetos dos indivíduos enquanto praticantes. Entender os objetivos organizacionais de modo estritamente performático é enxergar apenas a "ponta do iceberg" e não o acontecimento das organizações enquanto um fenômeno social. Os objetivos (senso de propósito) de uma organização, ao serem incorporados pelos atores sociais durante sua socialização, transformam-se em desejos, abarcando emoções, humores, sentimentos e afetos dos indivíduos enquanto praticantes do fazer estratégia. Dessa forma, a afetividade também pode orientar o que as pessoas fazem; o que pode ser entendido enquanto um traço antropológico dos seres humanos.

Por fim, percebo o fazer estratégia enquanto uma realização e não apenas como uma concepção intelectual, o que não se restringe ao contexto do carnaval. O fazer estratégia não ocorre no "vácuo", não sendo o resultado de decisões tomadas "aqui e agora" por estrategistas visionários. 0 fazer estratégia é uma realização de todos os envolvidos na concepção e na execução das atividades em torno das quais essa prática se desdobra, abarcando as percepções de seus praticantes em relação ao passado, presente e futuro.

Aproveite a leitura! 


\section{ÍNDICE}

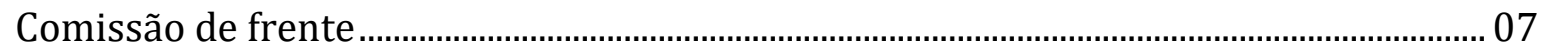

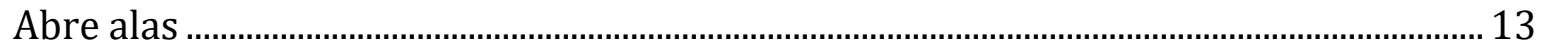

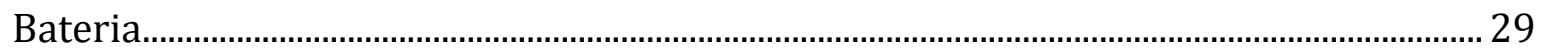

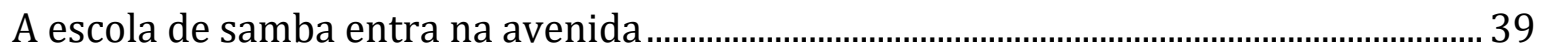

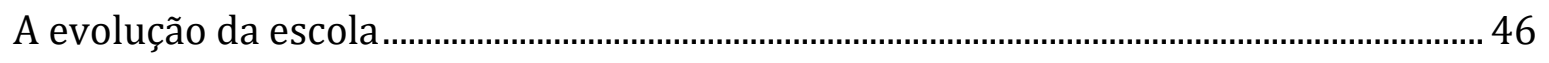

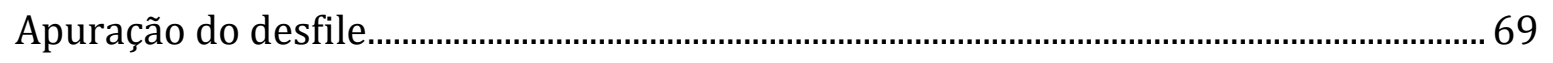

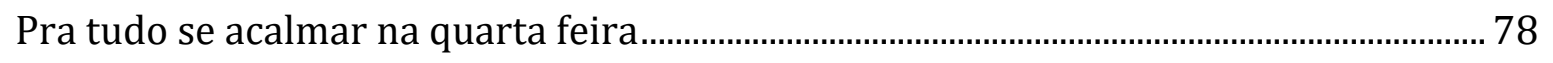


As escolas de samba ${ }^{1}$ são organizações tipicamente brasileiras, podendo ser definidas como associações recreativas e musicais, cujo objetivo principal é desfilar no carnaval (GOLDWASSER, 1975). Apesar de essas agremiações serem objeto de estudo da sociologia e da antropologia desde a década de 1960 e do significativo impacto econômico e social para o país, os estudos organizacionais lhe deram pouca atenção. Assim, a forma de organização de uma escola de samba e as práticas organizativas empregadas na produção de um desfile carnavalesco ainda não foram muito exploradas (TURETA; ARAÚJO, 2013).

Apesar da imagem de festa e falta de ordem ser comumente associada a essas agremiações, é interessante notar que uma escola de samba é capaz de desenvolver (durante todo um ano) e executar (por aproximadamente uma hora) uma apresentação complexa e organizada, o desfile de carnaval. O desfile carnavalesco é caracterizado pela apresentação de alas ${ }^{2}$ em uma sequência lógica, de modo que seja possível contar uma história -o enredo da escola de samba; podendo igualmente ser interpretado como o resultado de um grande e longo projeto, que envolve inúmeras pessoas (TURETA, 2011).

Assim, em um sentido mais amplo, o carnaval não significa apenas um grande festejo, e sim "[...] toda a sua preparação, ao longo da qual um novo enredo ${ }^{3}$ transformar-se-á gradualmente em samba-enredo ${ }^{4}$, em alegorias ${ }^{5}$ e em fantasias [...]" (CAVALCANTI, 1994, p. 15). Dessa forma, a produção do desfile de uma escola não é uma grande festa desordenada, e sim um conjunto organizado de atividades, de práticas organizativas (TURETA, 2011; TURETA; ARAúJO, 2013).

É na avenida, no desfile de carnaval, que o conjunto aparentemente tumultuado de pessoas (os integrantes e os foliões da agremiação) ganha forma (VERGARA; MORAES; PALMEIRA, 1997). Após o desfile, é chegada a hora da apuração, que se baseia em quesitos de julgamento ${ }^{6}$, regras instituídas e previamente definidas, que estabelecem as diretrizes básicas para a apresentação das agremiações. A cada ano, com o resultado das apurações, escolas "sobem" e "descem" para categorias superiores ou inferiores, respectivamente. Dessa forma, ressalta-se que as escolas de samba não disputam apenas o título de campeão do carnaval ou de seus grupos, mas também a permanência nesse grupo ou a ascensão para outro (CAVALCANTI, 1994).

Esse entendimento acerca das escolas (como uma organização que vai além da performance do desfile) e do desfile carnavalesco (como um conjunto organizado de atividades, de práticas organizativas) está alinhado com o movimento na área de Estudos Organizacionais em direção ao estudo das práticas (TURETA; ARAÚJO, 2013).

O movimento da prática ganhou força nas décadas de 1970 e 1980, quando o debate entre teoria e prática tornou-se central nas ciências sociais e influenciou as ciências organizacionais. Com isso, houve um enfoque das pesquisas nas práticas sociais e ocorreu uma "virada" em direção ao estudo da prática (SCHATZKI; KNORR-CETINA; SAVIGNY, 2001). O estudo das teorias da prática social passou, então, a ser uma alternativa conceitual em relação à teoria moderna clássica (RECKWITZ, 2002; FELDMAN; ORLIKOWSKI, 2011).

As teorias da prática podem ser rotuladas como teorias culturais, buscando entender e explicar a ação humana, assim como os significados das dinâmicas simbólicas que possibilitam e constrangem o comportamento e a interpretação dos agentes, dos atores sociais, em relação ao mundo. Assim, as teorias da prática rejeitam o individualismo metodológico, a tendência reducionista de se explicar o comportamento baseando-se totalmente

${ }^{1}$ Com o intuito de aproximar o leitor do universo do Carnaval e das escolas de samba, optou-se por usar termos que fazem alusão ao desfile carnavalesco para denominar os capítulos deste trabalho.

A comissão de frente é um dos quesitos apresentados pelas escolas de samba, sendo formada por até quinze integrantes, em geral bailarinos. A comissão de frente é uma ala coreografada, responsável por dar as boas vindas ao público e aos jurados. A coreografia elaborada e os trajes luxuosos de seus integrantes ajudam a contar o enredo, a história que está sendo apresentada no desfile carnavalesco.

${ }^{2}$ As alas, que representam parte do enredo que está sendo contado no desfile, são formadas por dezenas de pessoas que se apresentam com uma mesma fantasia.

${ }^{3}$ História que está sendo contada pela escola durante sua apresentação, durante o desfile carnavalesco.

40 samba-enredo é um tipo de samba que retrata o enredo escolhido para o desfile de uma escola. Assim, o sambaenredo é feito especificamente para o desfile carnavalesco.

${ }^{5}$ As alegorias também são chamadas de carros alegóricos. São carros ornamentados que representam parte do enredo, da história que está sendo contada no desfile carnavalesco. Nesses carros costuma haver esculturas e pessoas fantasiadas desfilando.

6 São quesitos previamente definidos e levados em conta na apuração do desfile. No carnaval de Vitória/ES, os quesitos casão: Bateria; Samba-Enredo; Harmonia; Evolução; Enredo; Conjunto; Alegorias e Adereços; Fantasias; Comissão de Frente e Mestre-Sala e Porta-Bandeira. 
na ação individual ou de grupos de indivíduos; contrapondo-se às figuras clássicas do "homo economicus" e do "homo sociologicus" e considerando que o indivíduo está imerso em um contexto social coletivo (RECKWITZ, 2002; FELDMAN; ORLIKOWSKI, 2011).

O termo "prática social" vai além da simples descrição da ação humana, da reprodução de um padrão de ação, de atividades rotinizadas (RECKWITZ, 2002), referindo-se a atividades humanas organizadas (SCHATZKI 2001, 2002, 2003, 2005). As práticas são "abertas" e melhor compreendidas através de seu dinamismo e movimento. Assim, a prática também inclui atividades irregulares, únicas e que estão em constante mudança (SCHATZKI, 2003).

As práticas são, ainda, um conjunto de ações corporais de "fazer" e "dizer" (o que não necessariamente envolve a fala), sendo o não fazer e o não dizer tidos, igualmente, como práticas sociais. Além disso, considera-se que o conjunto de atividades que compõe as práticas é um "nexo organizado de ações". Consequentemente, toda prática social é composta pelas dimensões atividade e organização (SCHATZKI, 2003). Além disso, dizer que as práticas são sociais é uma tautologia: a prática é social, uma vez que é um tipo de comportamento e de compreensão rotineiros, que aparecem em diferentes locais e em diferentes pontos do tempo, sendo realizados por diferentes atores (RECKWITZ, 2002). Em resumo, para as teorias da prática, a realidade é tida como socialmente construída, sendo a prática social sua unidade de análise.

Com a "virada" em direção ao estudo da prática, a ideia de que as organizações precisam ser analisadas como um processo emergente (organizing), composto por um conjunto de práticas que se encontram em constante estado de (re)constituição, resultado das interações sociais cotidianas, ganha espaço (CZARNIAWSKA, 2004, 2013; SCHATZKI, 2006; TURETA; ARAÚJO, 2013). Essa virada para a prática também influenciou as teorias sobre estratégia organizacional, que também passaram a ser vistas sob o enfoque dos estudos baseados em prática, que considera a abordagem da Estratégia como Prática Social- EPS (JARZABKOWSKI; BALOGUN; SEIDL, 2007; VAARA; WHITTINGTON, 2012; SEIDL; WHITTINGTON, 2014).

$\mathrm{Na}$ área de estratégia, estudos recentes, ao assumirem a estratégia como uma prática social, consideram-na como algo que as pessoas fazem no cotidiano organizacional e não como uma variável, um atributo organizacional, um processo top-down (da alta gerência para os demais níveis hierárquicos) e deliberado, levando em conta uma dimensão micro de análise (WHITTINGTON; CAILLUET, 2008; JARZABKOWSKI; SPEE, 2009; GOLSORKHI et al., 2010; WHITTINGTON, 2011; WHITTINGTON, 2014).

Para autores como Vaara e Whittington (2012), o poder da perspectiva da EPS está na habilidade de explicar como o fazer estratégia (strategizing) relaciona-se com as práticas organizacionais e sociais. Todavia, apesar de a abordagem da EPS apresentar-se como uma alternativa às perspectivas de análise macro, ao relacionar diferentes níveis de análise, a EPS se concentra em abordagens micro ${ }^{7}$, encontrando dificuldade em integrá-las com análises mais amplas. Nesse âmbito, pode-se afirmar que o potencial da perspectiva da estratégia como prática ainda não foi totalmente explorado (WHITTINGTON, 2006; VAARA; WHITTINGTON, 2012; SEIDL; WHITTINGTON, 2014). Assim, acredita-se que há uma lacuna de estudo na discussão do fenômeno da estratégia no âmbito organizacional (VAARA; WHITTINGTON, 2012; SEIDL; WHITTINGTON, 2014).

Além disso, em relação a produção do desfile de uma escola de samba, Araújo (2009) afirma que grande parte das agremiações já realiza um esforço considerável não para vencer o carnaval, mas para continuar existindo, para manter sua colocação no grupo ao qual pertence. Esse é o "carnaval de manutenção", um fenômeno especialmente presente quando se observa a conjuntura das pequenas ${ }^{8}$ escolas de samba (ARAÚJO, 2009). Pode-se afirmar que, a cada ciclo carnavalesco, o grande objetivo de uma agremiação não é necessariamente ganhar o carnaval, mas sim "colocar a escola na avenida", mantendo-se,

\footnotetext{
7 A terminologia "micro" e "macro" será utilizada apenas para fins didáticos, uma vez que a epistemologia de Schatzki em relação às práticas sociais e organizativas está para além dessa dicotomia.

80 termo "pequenas escolas de samba" não tem o intuito de ser pejorativo, sendo utilizado para destacar o fato de a grande maioria das agremiações brasileiras não fazer parte das escolas do grupo especial do Rio de Janeiro ou de São Paulo, das chamadas "super escolas de samba S.A." (HOLLANDA, 2013). Dessa forma, as pequenas escolas enfrentam uma realidade (especialmente em termos financeiros) muito distinta daquela que se apresenta para uma agremiação do grupo especial carioca ou paulista, o que faz com que o grande objetivo dessas agremiações seja "colocar a escola na avenida", e não necessariamente ganhar o título do desfile carnavalesco do ano corrente.
} 
preferencialmente, no grupo ao qual pertence. Durante a produção do desfile carnavalesco, várias atividades são realizadas tendo em vista esses objetos, o que lhes confere um caráter estratégico (JÚLIO; TURETA, 2015). Assim, considera-se ser possível fazer um paralelo entre o carnaval de manutenção e as práticas estratégicas da produção do desfile de uma escola.

Diante disso, o problema de pesquisa que direcionou a investigação deste trabalho foi: como se organizam as práticas estratégicas da produção do desfile carnavalesco de uma escola de samba? Para responder o problema de pesquisa, estabeleceu-se o seguinte objetivo geral: analisar a organização das práticas estratégicas da produção do desfile que contribuíram para que a escola de samba "fosse para a avenida".

Os objetivos específicos, por sua vez, foram: 1) identificar as práticas estratégicas da produção do desfile; 2) identificar as práticas estratégicas que contribuem para o carnaval de manutenção da escola; 3) examinar a dinâmica dos papéis dos atores sociais no fazer estratégia da escola de samba

Quanto à justificativa teórica, Chia e Mackay (2007) ressaltam que, ao lançar mão da lente da prática, os estudos que adotam a perspectiva da EPS deveriam se preocupar mais em definir o termo "prática social", guiando-se (teórica e empiricamente) por essa definição. Além disso, ao assumir que as organizações precisam ser analisadas como um acontecimento que se encontra em constante estado de (re)constituição (SCHATZKI, 2006), as perspectivas voltadas para a prática podem contribuir para a análise da forma organizacional da escola de samba, assim como para a compreensão da produção do desfile carnavalesco como um conjunto organizado de atividades, de práticas organizativas (TURETA; ARAÚJO, 2013).

Quanto à justificativa prática, entende-se que, ao assumir que as organizações precisam ser analisadas como um processo emergente, composto por um conjunto de práticas organizativas que se encontra em constante estado de (re)constituição (SCHATZKI, 2006; CZARNIAWSKA, 2004, 2013), as perspectivas voltadas para a prática poderiam contribuir para a análise da forma organizacional da escola de samba para além da performance do desfile, sendo nesse sentido que "o carnaval acontece o ano todo" (CAVALCANTI, 1994).

Diante disso, reconhecendo-se que há várias "teorias da prática" - como as perspectivas de Giddens, Bourdieu, De Certeau, Latour e Foucault, por exemplo (RECKWITZ, 2002) - destaca-se que este trabalho considera como referência teórica a epistemologia de Schatzki $(2002,2003,2005,2006,2010,2012)$ em relação às práticas sociais e organizativas, articulando essa perspectiva com a estratégia como prática social.

Theodore Schatzki é um teórico da prática contemporâneo. Seu trabalho é considerado uma das versões mais fortes e de longo alcance dentre as teorias da prática disponíveis até o momento (NICOLINI, 2013). Todavia, apesar de Schatzki ser um dos principais autores no campo das teorias da prática, seus trabalhos ainda carecem de aplicação empírica (SANTOS; SILVEIRA, 2015; SANTOS, 2014; NICOLINI, 2013), o que evidencia uma lacuna de estudos. Além disso, Schatzki compreende a prática social como um nexo, como um conjunto de atividades humanas organizadas, tendo cada prática uma organização própria (SCHATZKI, 2002, 2005). Dessa forma, torna-se relevante para o estudo da estratégia como prática entender como o fazer estratégia se organiza.

A escolha do objeto escola de samba deve-se ao fato de o mesmo possuir características que são interessantes para o estudo da estratégia como prática. Como outros agrupamentos de pessoas que se reúnem para alcançar um objetivo comum a partir de uma estrutura formal (MINTZBERG, 1980), as escolas de samba possuem suas próprias práticas organizativas (TURETA; ARAÚJO, 2013). Por outro lado, essas agremiações possuem características próprias. O improviso, o trabalho voluntário e as fortes relações afetivas, por exemplo, coexistem com o planejamento, a terceirização e a contratação de profissionais especializados, o que cria a especificidade das escolas de samba (BLASS, 2007).

Percebe-se, ainda, que essas agremiações fazem parte de um mundo relacional, dada a importância que as relações pessoais assumem nos processos organizacionais. Assim, o clássico, o inovador, o planejamento, a criatividade, a racionalização, o desperdício, a seriedade, a alegria, o sonho e a realização interagem, sendo o desfile de carnaval a síntese de uma escola (VERGARA; MORAES; PALMEIRA, 1997). É interessante notar que uma das características das teorias da prática é justamente superar as várias dicotomias estabelecidas pelas teorias sociais modernas, deslocando a ênfase para as relações entre os atores sociais e as práticas cotidianas.

Apesar de as pessoas se reunirem com uma finalidade, não há a imposição rígida de objetivos (pelo menos na conjuntura das pequenas escolas), o que permite que a escola de samba possa se (re)inventar 
constantemente. Conforme mencionado, nessas agremiações, o conjunto aparentemente desordenado de pessoas ganha forma e organização na avenida, no desfile de carnaval (VERGARA; MORAES; PALMEIRA, 1997).

Além disso, no mundo do carnaval, as grandes e as pequenas escolas de samba coexistem. Entretanto, os pesquisadores, em geral, se interessam pelo ápice do carnaval, pelas grandes escolas do grupo especial, pelas agremiações que crescem e ganham notoriedade. Percebe-se, assim, que há uma relação de competição, inclusão e exclusão mais ou menos declarada entre elas, uma vez que essas agremiações competem por artistas, investidores, patrocinadores e público (ARAÚJO, 2009), pela permanência em seus grupos e pela ascensão para outros grupos (CAVALCANTI, 1994).

Assim, entender uma escola de samba apenas como uma empresa e interpretar o desfile carnavalesco simplesmente como uma produção comercial seriam meias verdades. Uma escola não opera exclusivamente em uma lógica empresarial, nem é uma organização fechada em si mesma, no mundo do samba ou do carnaval (GOLDWASSER, 1975; TURETA; ARAÚJO, 2013).

Diante disso, para realizar o trabalho proposto, adotam-se como referenciais teóricos a epistemologia da prática segundo Schatzki e a perspectiva da estratégia como prática social.

Dessa forma, com o intuito de alcançar o objetivo geral, e considerando-se o caráter complementar e mutuamente enriquecedor dos diferentes instrumentos de coleta de dados (STAKE, 1994), realizou-se este estudo por meio da triangulação da observação participante com inspiração etnográfica (com descrição densa das observações registradas em diários de campo), com entrevistas exploratórias e semiestruturadas em profundidade, pesquisa documental e imagens/fotografias. A pesquisa desdobrou-se entre outubro de 2014 e março de 2015. O acesso ao campo se deu no final do mês de outubro. No entanto, a pesquisa começou a acontecer de modo sistemático a partir de dezembro.

Considera-se, assim, que as práticas em si somente podem ser acessadas por meio da observação, uma vez que as entrevistas tornam acessíveis apenas os relatos dessas práticas (FLICK, 2004). Dessa forma, para que o processo de produção do desfile carnavalesco pudesse ser analisado, acompanhou-se, por meio da observação participante, o cotidiano da escola de samba em diferentes espaços/contextos organizacionais: ateliês (onde as fantasias foram confeccionadas), barracão pesado (onde os carros alegóricos foram produzidos), sede (onde reuniões aconteceram), quadra da escola (onde reuniões e ensaios gerais ocorreram), ruas do bairro (onde se deu o ensaio de rua), sambão do povo (local de realização do ensaio técnico e do desfile carnavalesco) e ginásio de esportes do clube Álvares Cabral (local de realização da apuração do desfile carnavalesco).

As entrevistas foram outra fonte de dados. As mesmas foram realizadas durante e após a observação, entre os meses de janeiro de 2015 e março de 2015, sendo os sujeitos selecionados de acordo com seu tempo como integrante da escola. As entrevistas foram divididas em dois grupos: entrevistas exploratórias e entrevistas em profundidade com roteiro semiestruturado. Ao todo foram realizadas 23 entrevistas, sendo oito exploratórias e 15 em profundidade.

A análise documental, por sua vez, conta com samba alusivo ${ }^{9}$ da escola, enredos, sambas-enredos, regulamento do carnaval $^{10}$, setorização do desfile carnavalesco ${ }^{11}$, script do desfile carnavalesco ${ }^{12}$ e resultado final da apuração do carnaval.

\footnotetext{
${ }^{9} 0$ samba alusivo é mais curto, com apenas uma estrofe. Essa canção costuma narrar o amor e o bem querer dos integrantes em relação à escola, exaltando a agremiação. Esse samba costuma ser cantado pelos intérpretes da escola antes do samba-enredo, durante os ensaios e no desfile carnavalesco. 0 samba alusivo difere-se do samba exaltação justamente por ser mais curto.

100 regulamento do carnaval é documento público disponibilizado pela liga das escolas de samba do Espírito Santo (LIESES) a todas as agremiações.

11 A setorização do desfile carnavalesco é um documento interno da escola de samba que trata do roteiro de apresentação do desfile carnavalesco, da ordem sequencial das alas e dos carros alegóricos. 0 documento também descreve quais serão as alas coreografadas e quem serão os coreógrafos da comissão de frente, os casais de mestre sala e porta bandeira, o mestre de bateria e os destaques da escola de samba. A setorização é produzida pela diretoria de carnaval e disponibilizada para as demais diretorias.

12 O script do desfile carnavalesco é um documento produzido pela diretoria de carnaval e enviado para a liga das escolas. 0 envio do script é uma obrigação das escolas e está previsto no regulamento do carnaval. 0 documento descreve o enredo, o samba-enredo e a ordem sequencial de apresentação do desfile carnavalesco (setorização), assim como o que cada elemento do desfile (alas, carros alegóricos, comissão de frente, casais de mestre-sala e porta-bandeira e destaques) representa.
} 
Em relação à análise e interpretação dos dados, este trabalho emprega o procedimento de análise de conteúdo temático a posteriori (FRANCO, 2012; KRIPPENDORFF, 2004), seguindo o procedimento em espiral de análise de dados proposto por Creswell (2012).

Por fim, para realizar a discussão proposta, este trabalho está organizado em três sessões, além desta introdução: No próximo capítulo apresenta-se a fundamentação teórica, discutindo-se a epistemologia de Schatzki em relação às práticas sociais, assim como a perspectiva da estratégia como prática. Posteriormente, apresenta-se o método de pesquisa adotado, relatando-se também o acesso ao campo. Finaliza-se, então, este trabalho com a apresentação da escola de samba e das práticas estratégicas empregadas na produção de seu desfile carnavalesco, a discussão dos resultados encontrados e as referências utilizadas. 


\section{ABRE-ALAS ${ }^{13}$}

Neste capítulo apresentam-se as bases teóricas que orientam este trabalho, discutindo-se a epistemologia da prática segundo Schatzki e a perspectiva da estratégia como prática social. Assim, no intuito de esclarecer ao leitor alguns dos conceitos-chave dos referenciais teóricos adotados, diversos autores são trazidos ao longo do texto. Não há, porém, a pretensão de se esgotar a revisão de literatura do referencial teórico utilizado como lente de análise.

\subsection{TEORIAS DA PRÁTICA E EPISTEMOLOGIA DE SCHATZKI}

Nas décadas de 1970 e 1980, o debate entre teoria e prática torna-se central nas ciências sociais e influencia as ciências organizacionais. Com isso, houve um enfoque das pesquisas nas práticas sociais e ocorreu uma "virada" em direção ao estudo da prática (SCHATZKI; KNORR-CETINA; SAVIGNY, 2001), o que demonstra um forte interesse em relação às práticas cotidianas dos atores sociais na produção da vida social (DENIS; LANGLEY; ROULEAU, 2007). A virada para a prática é vista como uma reação, como um questionamento em relação às abordagens sistêmicas e deterministas que dominaram a sociologia norte-americana até o final da década de 1970 (DENIS; LANGLEY; ROULEAU, 2007).

O termo "prática social" vai além da simples descrição da ação humana ou da reprodução de um padrão de ação (RECKWITZ, 2002), referindo-se a um conjunto de atividades humanas organizadas (SCHATZKI, 2002, 2003, 2005, 2006, 2010, 2012). Entende-se que as práticas são "abertas" e melhor compreendidas através de seu dinamismo e movimento. Assim, a prática também inclui atividades irregulares, únicas e que estão em constante mudança (SCHATZKI, 2003).

As práticas são, ainda, um conjunto de ações corporais de "fazer" e "dizer". Além disso, considera-se que o conjunto de atividades que compõe as práticas é um "nexo organizado de ações". Consequentemente, toda prática social é composta pelas dimensões atividade e organização (SCHATZKI, 2003).

Para a perspectiva da prática, os fenômenos sociais não são independentes, havendo uma relação recursiva, reflexiva entre eles. Percebe-se, assim, uma tentativa de reconciliação entre os níveis micro e macro de análise, entre os fenômenos agente e estrutura. O que reflete a rejeição do dualismo e a constituição mútua dos fenômenos - princípios das teorias da prática (FELDMAN; ORLIKOWSKI, 2011). Em resumo, para as teorias da prática, a realidade é socialmente construída, sendo a prática social sua unidade de análise.

A virada em direção à prática também influenciou os estudos organizacionais. Tal atração crescente pela perspectiva da prática pode ser explicada pelo modo particular de a abordagem entrar em ressonância com o mundo contemporâneo, um mundo cada vez mais interconectado, em que as entidades sociais aparecem como o efeito de um trabalho complexo e em curso, em que as fronteiras em torno dessas entidades estão cada vez mais difíceis de serem definidas (NICOLINI, 2013). As organizações contemporâneas, por exemplo, são cada vez mais complexas, dinâmicas e transitórias. Para melhor entendê-las, o pesquisador precisa de abordagens que teorizem esses fenômenos emergentes e muitas vezes indeterminados. Nesse sentido, a lente da prática tem muito a oferecer para os estudos organizacionais, uma vez que para essa perspectiva a vida social é uma produção contínua, que emerge através das ações recorrentes e cotidianas das pessoas (FELDMAN; ORLIKOWSKI, 2011; SCHATZKI, 2006).

É necessário salientar que não há uma teoria unificada da prática. Entretanto, é possível afirmar que as várias perspectivas da prática constituem, de forma bastante ampla, uma família de abordagens teóricas ligadas por uma rede de semelhanças históricas e conceituais (NICOLINI, 2013). Uma das semelhanças dessas várias perspectivas, por exemplo, é a noção de que a vida social é uma produção contínua e, portanto, emerge através das ações recorrentes e cotidianas das pessoas (FELDMAN; ORLIKOWSKI, 2011; SCHATZKI, 2006). Para Nicolini (2013), muito seria obtido se os estudiosos e pesquisadores apreciassem as semelhanças e as diferenças entre as teorias da prática, e se, especialmente, fizessem com que essas diferenças trabalhassem em prol de suas pesquisas e dos estudos baseados em prática como um todo.

Diante disso, apesar das diferenças entre os teóricos da prática, Nicolini (2013) e Feldman e Orlikowski (2011) destacam que é possível assinalar um conjunto de princípios analíticos comuns a essa família de

130 abre-alas é o primeiro carro alegórico do desfile carnavalesco de uma escola de samba, antecedendo as alas, conforme sugere o termo. Devido ao seu tamanho, luxo e beleza, o carro abre-alas é um dos maiores elementos visuais de um desfile. Em sua parte frontal, costumam estar representados o símbolo e o nome da agremiação. 
abordagens, a saber: consequencialidade das práticas, rejeição dos dualismos e constituição mútua dos fenômenos sociais. Segundo a consequencialidade das práticas, a vida social e as estruturas sociais são consequências das práticas cotidianas. A rejeição dos dualismos, por sua vez, considera que os fenômenos sociais - como agente e estrutura, e estabilidade e mudança - não são independentes, considerando essas dicotomias como formas de simplificação e/ou reducionismo. Assim, busca-se a redefinição e a reintegração de conceitos. Já a constituição mútua dos fenômenos compreende que os fenômenos sociais são reflexivos, havendo uma relação recursiva entre eles. Assim, os fenômenos agente e estrutura, e estabilidade e mudança são mutuamente constituídos.

Conforme já mencionado, reconhecendo-se que há várias "teorias da prática" - como as perspectivas de Giddens, Bourdieu, De Certeau, Latour e Foucault, por exemplo (RECKWITZ, 2002) - destaca-se que este trabalho considera como referência teórica a epistemologia de Theodore Schatzki $(2002,2003,2005,2006$, 2010) em relação às práticas sociais e organizativas.

\subsubsection{EPISTEMOLOGIA DA PRÁTICA SEGUNDO SCHATZKI}

Apesar de Schatzki ser um dos principais autores no campo da epistemologia da prática, seus trabalhos ainda necessitam de aplicação empírica (SANTOS, 2014; NICOLINI, 2013). No Brasil, por exemplo, as ideias de Schatzki têm sido usadas na análise das práticas organizacionais ainda de forma emergente (ver SANTOS; SILVEIRA, 2015; SANTOS, 2014; OLIVEIRA; CAVEDON, 2013; TURETA, 2011). Na revisão de literatura deste trabalho, encontrou-se apenas os trabalhos de Santos (2014) e de Júlio e Tureta (2015) como exemplo de aplicação empírica direta das ideias de Schatzki no Brasil.

De acordo com a perspectiva de Schatzki, as práticas sociais são o principal elemento constitutivo da vida social, da ordem social, o ponto de partida para qualquer investigação ou entendimento das relações humanas e sociais (NICOLINI, 2013). O autor define o termo "prática social" para além da simples descrição da ação humana rotinizada, referindo-se a atividades humanas organizadas, a um conjunto de ações corporais de "fazer" e "dizer" (o que, necessariamente, não precisa envolver a fala; uma vez que alguém pode "dizer" algo gestualmente); sendo o não fazer e o não dizer tidos, igualmente, como práticas (SCHATZKI, 2001, 2002, 2003, 2005). Definir a prática como uma atividade significa compreendê-la como um "pacote" de ações. Por exemplo, escrever um trabalho como este envolve definir um problema de pesquisa, revisar literatura, refletir, assistir aulas, participar de congressos, conversar com o professor-orientador, produzir um texto acadêmico, etc. Assim, cada uma dessas atividades (ou conjunto de ações de "fazer" e "dizer") compõe a prática "escrever uma um trabalho acadêmico". Além disso, a prática social é entendida como um conjunto de múltiplas ações situadas no tempo e no espaço, ou seja, em um dado contexto (SCHATZKI, 2001). No caso do exemplo exposto acima, esse contexto seria o meio acadêmico, o campo dos Estudos Organizacionais.

Em relação ao conjunto de ações corporais de "fazer" e "dizer", Santos (2014, p. 31) destaca que:

Fazeres e dizeres, como entendidos aqui, correspondem àquelas ações básicas que as pessoas executam diretamente com o corpo (andar, olhar, ler, digitar um texto, pronunciar uma palavra, chutar uma bola, entregar alguma coisa para alguém, etc.) [...] incluindo aqui, ainda, qualquer extensão (uma bengala ou um óculos, por exemplo) que esse corpo possa ter [...].

Assim, a prática social é um conjunto de múltiplas atividades humanas organizadas e de arranjos materiais, o que inclui humanos e não humanos, o corpo dos indivíduos e eventuais extensões desse corpo (SCHATZKI, 2002, 2005).

Além disso, Schatzki salienta que não há fronteiras rígidas separando as práticas, uma vez que as mesmas são abertas e melhor compreendidas através de seu dinamismo e movimento. Assim, as práticas sociais podem se sobrepor. Ou seja, uma ação de "fazer" ou "dizer" pode pertencer a mais de uma prática. As práticas também incluem atividades irregulares, únicas e que estão em constante mudança (SCHATZKI, 2003). Assim, considera-se que a ordem social não é mero sinônimo de regularidade e que a mesma tampouco requer uma repetição uniforme, mas sim similaridades entre as atividades (SCHATZKI, 2001).

Ao analisar as práticas sociais como o principal elemento constitutivo da vida social, Schatzki desenvolveu uma visão bem específica da ação humana, afirmando que as pessoas fazem aquilo que faz sentido para elas. $\mathrm{O}$ argumento baseia-se em um traço antropológico fundamental dos humanos, que os distingue de outros primatas: Nós humanos somos animais autointerpretativos. $\mathrm{O}$ autor denominou essa condição humana 
de inteligibilidade da ação, derivando daí seu conceito de inteligibilidade das práticas sociais (NICOLINI, 2013).

É a inteligibilidade que dá sentido, significado, à performance dos praticantes e à prática propriamente dita. A atividade humana é governada por essa inteligibilidade, uma vez que os indivíduos fazem o que tem sentido (ou propósito, finalidade) fazer. A inteligibilidade das práticas organiza, assim, a ação dos praticantes e as práticas sociais; sendo as práticas sociais inteligíveis por serem dotadas dessa finalidade (NICOLINI, 2013; SCHATZKI, 2002).

A intencionalidade é, ainda, um fenômeno individual. É sempre para um indivíduo que uma ação específica faz ou não sentido. Todavia, o entendimento que se tem sobre uma prática não é do indivíduo, mas sim impessoal e público (social, como a prática), podendo ser acessível a qualquer um, a qualquer praticante (SCHATZKI, 2002). Além disso, a inteligibilidade da prática não é sinônimo de racionalidade ou tampouco é governada pela normatividade, sendo a maioria das ações humanas uma (re)ação emergente e não refletida do indivíduo (que executa atividades rotinizadas que são aprendidas), uma ação guiada por um senso de propósito/finalidade que é socialmente construído e incorporado pelos praticantes de uma determinada prática (NICOLINI, 2013; SCHATZKI, 2002).

\subsubsection{COMO AS PRÁTICAS SE ORGANIZAM}

As práticas sociais não são apenas performances corporais rotineiras, mas também, e ao mesmo tempo, conjuntos de atividades mentais. Assim, a prática social implica, necessariamente, determinadas maneiras rotineiras de compreender o mundo, de desejar algo, de saber o que, e como fazer alguma coisa (RECKWITZ, 2002). Dessa forma, rompe-se com uma das dicotomias das Teorias sociais clássicas: corpo Vs. mente (SANTOS, 2014). O que, para a epistemologia da prática de Schatzki, não é uma contradição, uma vez que padrões corporais e mentais são componentes necessários, inerentes, das práticas e, portanto, da vida social. Conforme observa Reckwitz (2002, p. 252):

[...] within the practice these bodily performances are necessarily connected with certain know-how, particular ways of interpretation lof the other players' behaviour, for example), certain aims (most of all, of course, to win the game) and emotional levels (a particular tension) which the agents, as carriers of the practice, make use of, and which are routinized as well. [...] a social practice consists of certain bodily and certain mental activities. If somebody 'carries' (and 'carries out') a practice, he or she must take over both the bodily and the mental patterns that constitute the practice.

Diante disso, retomando o exemplo exposto acima, pode-se afirmar que a prática "escrever um trabalho acadêmico" não envolve apenas as ações corporais de sentar-se em frente a um computador e digitar. Escrever um trabalho como este envolve interpretação, modos particulares de compreender o mundo (sob a lente teórica da prática, por exemplo), desejos/propósitos (ter o título de mestre, fazer doutorado e/ou seguir carreira acadêmica), assim como estados emocionais (ansiedade, medo, felicidade, realização, etc.).

Nesse contexto, sendo a prática social um nexo, uma malha, um conjunto de múltiplas ações organizadas (ou seja, estruturadas), destaca-se que a organização dessas práticas se dá em torno de três fenômenos: entendimentos, regras e teleoafetividade (SCHATZKI, 2002, 2005). Assim, são esses elementos que fazem com que determinadas ações de "fazer" e "dizer" estejam reunidas sob uma mesma atividade humana, em torno de uma mesma prática social (SANTOS; SILVEIRA, 2015).

O entendimento da prática refere-se ao know-how, à habilidade de um praticante realizar determinadas atividades que compõem uma prática, assim como a capacidade de esse praticante entender essa prática (que por sua vez, é dotada de significado e propósito para o praticante). O entendimento da prática é social, é compartilhado pelos praticantes, que concordam (ou seja, têm o mesmo julgamento), pelo menos tacitamente, em relação ao que faz sentido fazer ou não fazer, ou que deve ou não ser feito (SCHATZKI, 2002). Entendimentos e know-how são propriedades das práticas e não características dos indivíduos. Durante sua socialização, os indivíduos aprendem como participar de determinadas práticas, adquirindo e incorporando versões dos elementos que organizam essas práticas (SCHATZKI, 2002; RECKWITZ, 2002). Nesse sentido, podese afirmar que "jogar futebol" (ou praticar outro esporte qualquer) é uma prática e que "saber como jogar futebol" não é uma habilidade de um indivíduo (que até pode saber como executar essa prática), mas sim um know-how dos praticantes. 
Dessa forma, um indivíduo que não é socializado na prática de jogar futebol não saberia como jogar ou como se joga, não teria habilidade de executar (de correr com a bola, driblar ou chutar) ou entender (o que é impedimento, o que significam os cartões amarelo e vermelho) essa prática esportiva. Entende-se, assim, que "a noção de entendimento de Schatzki [...] é uma habilidade ou capacidade que está "por trás" das atividades humanas (e não das pessoas), ou seja, que "suporta" as práticas" (SANTOS, 2014, p. 36).

As regras, por sua vez, dizem respeito às normas, princípios, instruções, critérios de decisão ou convenções sociais que são formulados e prescritos (de forma mais ou menos explícita, ou até mesmo implícita), sendo socialmente aceitos e compartilhados (SCHATZKI, 2002). Todavia, ressalta-se que, para Schatzki (2002), as regras não estão necessariamente vinculadas a mecanismos de poder e autoridade, ou a sanções; além de não serem fundamentalmente a explicitação de um entendimento.

As regras seriam mais bem compreendidas como uma forma de codificação das regularidades das ações passadas, que, por sua vez, podem ter (e comumente têm) uma força normativa e influenciar o curso das ações futuras, especificando quais ações e como essas ações podem e devem ser executadas (SANTOS; SILVEIRA, 2015). Assim, as regras que organizam as práticas e regulam as atividades evidenciam uma relação recursiva entre o tempo passado, presente e futuro (SCHATZKI, 2002).

Dessa forma, as regras guiam, prescrevem e censuram a ação dos indivíduos, conectando fazeres e dizeres (SCHATZKI, 2002); uma vez que os indivíduos (como praticantes) as observam e as levam em consideração para julgar o que faz ou não sentido fazer, o que convém, ou pelo menos é aceitável, fazer ou não fazer (SCHATZKI, 2002). É importante destacar que “[...] o efeito normativo das regras é praticado, e não prédeterminado. Nenhum curso de ação (fazer/dizer) deve ser visto, a priori, como determinado por uma dada regra [...]"(SANTOS, 2014, p. 36). Assim, enquanto os elementos entendimento e teleoafetividade organizam o que faz sentido fazer (senso de propósito ou finalidade), as regras revelam-se como um elemento com potencial normativo; organizando as práticas e as atividades dos indivíduos enquanto praticantes (SANTOS, 2014).

Como ocorre com os entendimentos, durante sua socialização, os indivíduos aprendem quais regras organizam as práticas nas quais eles são praticantes (SCHATZKI, 2002), incorporando versões desse elemento. Por exemplo, um praticante da prática de "jogar futebol" pode incorporar versões das regras que organizam essa prática e considerar que "faz sentido", que convém ver os jogos do seu time toda quarta-feira à noite, executando essa ação, esse "fazer". Para um indivíduo que não foi socializado nessa prática, assistir aos jogos toda quarta-feira à noite não faria nenhum sentido. Vale ressaltar que, nesse último caso, as regras que organizam a prática de "jogar futebol" não teriam nenhum potencial normativo.

Já a teleoafetividade refere-se ao senso de propósito (fins e meios para se alcançar esse fim), que, conforme mencionado, é um traço antropológico básico dos humanos, uma complexa combinação de propósitos, emoções e humor dos indivíduos. Esses elementos também são aprendidos pelos indivíduos no processo de socialização das práticas, sendo reforçados pela repetição dessas práticas e por sanções (explícitas ou tácitas) (NICOLINI, 2013; SCHATZKI, 2002). Assim, segundo Schatzki (2001), citado por Santos e Silveira (2015, p. 87), "[...] o que faz sentido para uma pessoa fazer (ou a inteligibilidade prática) depende, em grande medida, dos fins que ela persegue coordenados com os afetos que ela "sente" ao se engajar em uma determinada prática [...]". Além disso, a teleoafetividade que organiza uma determinada prática é socialmente compartilhada por seus praticantes, sendo aceita e considerada legítima no contexto dessa prática (SCHATZKI, 2002).

É interessante notar que a teleoafetividade vai além do senso de propósito, abarcando emoções, humores, sentimentos e afetos; que também podem ser entendidos como traços antropológicos básicos dos seres humanos. De acordo com essa perspectiva, a afetividade também pode orientar o que as pessoas fazem, independente de seu senso de propósito (SCHATZKI, 2002; SANTOS, 2014). Mais uma vez, como ocorre com os demais elementos que organizam as práticas, os indivíduos socializados em torno de uma determinada prática incorporam versões da teleoafetividade que a organiza (SCHATZKI, 2002).

Diante disso, retomando o exemplo da prática de "jogar futebol”, observa-se que para um praticante dessa prática ficar irritado ou até mesmo chorar (exemplos de humores e emoções) ao assistir uma partida do seu time "do coração" é legítimo. Do mesmo modo, endividar-se para acompanhar uma copa do mundo (senso de propósito) também pode ser compreensível.

Conforme já mencionado, Schatzki (2005) afirma que os elementos que organizam as práticas (entendimentos, regras e teleoafetividade) são incorporados pelos praticantes durante seu processo de 
socialização. Dessa forma, o entendimento de uma prática social se transforma em know-how, as regras em crenças e a teleoafetividade (senso de propósito ou finalidade) em desejo. Esses elementos são incorporados de modo diferente, sendo combinados de diversas maneiras, uma vez que os indivíduos não são idênticos (possuem socialização, experiências, inteligência, poder de observação e status distintos). Assim, cada indivíduo (enquanto praticante) carrega consigo uma "microversão" dos elementos que organizam as práticas das quais fazem parte.

Todavia, apesar dessas diferenças, há uma estrutura comum que é socialmente compartilhada pelos praticantes, uma vez que o entendimento geral da prática é social (SCHATZKI, 2005). Para o autor, tais estruturas compartilhadas também podem ser entendidas como estados mentais (o que abarca intenções, motivações, atitudes, interesses, crenças e desejos; ou seja, os elementos entendimentos, regras e teleoafetividade). Por serem socialmente compartilhados, os estados mentais são propriedades das próprias práticas e não dos indivíduos, sendo, por isso, tidos como estados mentais objetivos (ou mentalidade objetiva das práticas). São os estados mentais compartilhados que se relacionam com os padrões de ação, com as atividades rotinizadas que, muitas vezes, caracterizam as práticas sociais (SCHATZKI, 2005; SANTOS, 2014).

\subsubsection{ONTOLOGIA DE CONTEXTO: PARA ALÉM DA AGÊNCIA E DA ESTRUTURA}

A inteligibilidade das práticas só é possível por meio de um entendimento prévio da situação, do contexto no qual as práticas se desdobram e acontecem. Assim, esse contexto pode ser compreendido como um espaço de inteligibilidade (clearing). Esses espaços de inteligibilidade, por sua vez, são inerentemente sociais e coletivos, assim como situacionais, historicamente situados no tempo (em determinada época) e no espaço (em determinado locus) (NICOLINI, 2013). Dessa forma, de acordo com Schatzki (2005), as práticas sociais também podem ser entendidas como arenas sociais (por envolverem várias pessoas) e coletivas (porque são comuns a essas pessoas) de ação, permeadas de espaços de inteligibilidade (espaços nos quais os indivíduos vivem, interagem e convivem de modo inteligível).

Nesse âmbito, Schatzki $(2001,2005)$ aborda a ontologia de contexto (site ontology), um contraponto às ontologias individualistas e societistas, tidas como dicotômicas e reducionistas devido à incompletude do individualismo e à despersonalização e reificação do societismo. O individualismo é visto como uma dimensão do fenômeno social. Uma vez que não há algo para além do individual, não há um "nível" acima dos fenômenos sociais, dotado de uma natureza distinta desses fenômenos. Dessa forma, enquanto as ontologias individualistas e societistas se articulam em torno da dicotomia entre indivíduo e sociedade, a ontologia de contexto assume que as características individuais são "ontologicamente contínuas" às características do contexto social (SCHATZKI, 2005; SANTOS, 2014).

Assim, os fenômenos que povoam o campo organizacional (como instituições, mecanismos de controle, sistemas de regras ou procedimentos) devem ser (re)conceitualizados como aspectos da complexa malha de práticas organizadas e arranjos materiais, ou seja, como fenômenos sociais quaisquer, que podem estar organizados em menor ou maior escala/extensão, conforme sugere a ideia de fractal ${ }^{14}$.

De acordo com a ontologia de contexto, a vida social, ou seja, a coexistência humana, não é uma ordem autossustentada que se propaga automaticamente, estando intrinsecamente ligada a um tipo de contexto, sendo parte inerente, se desdobrando, existindo nesse contexto (SCHATZKI, 2002, 2005; SANTOS, 2014). Dessa forma, o contexto é fundamental para analisar e explicar os fenômenos sociais. É importante enfatizar que esse contexto é entendido como uma arena social historicamente situada (onde os fenômenos sociais e as práticas sociais se desdobram) e não necessariamente como um lugar espacial ou físico (SCHATZKI, 2005).

As entidades (humanas e não humanas) e a complexa malha de práticas e arranjos são partes inerentes desse contexto (SCHATZKI, 2005). Assim, o contexto não é apenas uma arena social na qual os fenômenos sociais acontecem, não estando as entidades e a malha apenas imersas nesse contexto; uma vez que entidades e malha são o próprio contexto (SCHATZKI, 2002, 2005).

Isso faz com as práticas também tenham um caráter de organizadoras - dando coerência, constituindo o contexto, a ordem social (OLIVEIRA; CAVEDON, 2013). Assim, além de serem organizadas (em torno de entendimentos, regras e teleoafetividade) e inteligíveis (por meio do contexto), as práticas também dão coerência, organizam o contexto social. É nesse sentido que as práticas são tidas como mecanismos que

14 Figura geométrica cujas partes apresentam o mesmo aspecto, sendo autossimilares, independente da escala em que são observadas. 
geram ordenamento (SCHATZKI, 2005), indo além da descrição da ação humana ou da reprodução de um padrão de ação, de rotinas (RECKWITZ, 2002).

Diante disso, é possível argumentar que a perspectiva de Schatzki está para além da agência e da estrutura, ou seja, para além da rejeição dos dualismos ou da constituição mútua dos fenômenos sociais, centrando-se na redefinição e na reintegração de conceitos.

\subsubsection{ORGANIZAÇÕES COMO FENÔMENOS SOCIAIS E COMO ACONTECIMENTOS}

Um exemplo de fenômeno social que se desdobra nesses contextos, nesses espaços de inteligibilidade (clearing), são as organizações. Dessa forma, Schatzki (2005) considera que as organizações, assim como outros fenômenos sociais quaisquer, são uma malha de práticas organizadas e arranjos materiais (objetos materiais, layouts, conexões materiais entre indivíduos) que acontecem nesses contextos, nessas arenas sociais.

É interessante notar que malhas, práticas e arranjos estão interconectados, formando uma ordem social local, em menor escala: um setor ou departamento de uma organização, por exemplo. Diversas malhas de práticas e arranjos, por sua vez, podem se sobrepor, constituindo uma ordem social ampliada, em maior escala: como uma organização. De modo análogo, malhas de práticas e arranjos podem estar conectadas, formando uma rede de organizações (governo e empresas, por exemplo) que se relacionam em um dado campo organizacional, ou seja, em um contexto com escala ainda maior (SANTOS; SILVEIRA, 2015).

Assim, a noção de que a ordem social é uma malha de práticas sociais e arranjos materiais têm potencial para analisar diversos fenômenos organizacionais (SANTOS; SILVEIRA, 2015), evidenciando a ideia de que as organizações são o resultado de processos organizativos (organizing) (CZARNIAWSKA, 2004, 2008) que podem se sobrepor, não reificando a rigidez de uma estrutura organizacional estática e formal-funcional.

Além disso, Schatzki (2005) afirma que as organizações asseguram sua existência por meio da perpetuação das práticas e dos arranjos materiais que as compõem, acomodando evoluções e mudanças nessa complexa malha. Vale salientar que as práticas que compõem uma organização não são estáticas, sendo mais bem entendidas por meio de seu dinamismo. Todavia, as mudanças que ocorrem se dão de modo gradual: alteram-se alguns dos componentes da malha organizacional, enquanto outros persistem inalterados; sendo a ação humana a fonte primária de mudança de quaisquer conjuntos organizados de práticas e arranjos.

Schatzki (2006) também trata as organizações como um acontecimento, como um fenômeno social que é realizado (performance). Assim, as organizações são analisadas como um processo emergente (organizing) que se encontra em constante estado de (re)constituição, como o resultado das interações sociais cotidianas (CZARNIAWSKA, 2004, 2008; SCHATZKI, 2006). Dessa forma, "[...] as organizações não são 'coisas' prontas e acabadas, estruturas inanimadas, mas 'coisas' vivas, animadas, continuamente feitas e refeitas, produzidas e reproduzidas, no cotidiano" (SANTOS, 2014, p. 13); o resultado de um processo organizativo (CZARNIAWSKA, 2004, 2008) que envolve elementos humanos e não humanos, "fazeres" e "dizeres", regras, entendimentos, finalidades e emoções.

É necessário destacar que entender uma organização como um acontecimento não é simplesmente observar o acontecimento, a performance dessa organização (SCHATZKI, 2006). Diante disso, Schatzki afirma que as organizações acontecem em um tempo real, havendo dois tipos de tempo real (o objetivo e o teológico). 0 tempo objetivo relaciona-se com o desdobramento dos acontecimentos, sendo definido pela sucessão cronológica de eventos. Já o tempo teológico trata da co-ocorrência de um passado teleológico, assim como das ações organizacionais do presente e do futuro. Assim, há uma relação recursiva entre passado, presente e futuro. A motivação de uma ação está no passado, a atividade em si ocorre no presente, enquanto que a ação tem sua intenção/finalidade projetada para o futuro (SCHATZKI, 2006).

Dessa forma, uma organização (como um fenômeno social qualquer) não é somente um nexo de práticas ordenadas e de arranjos materiais, mas também um nexo recursivo de suas ações passadas, presentes e futuras, o que compõe a memória das práticas. Além disso, também há uma relação recursiva entre os elementos (entendimentos, regras e teleoafetividades) passados, presentes e futuros que organizam as práticas (SCHATZKI, 2006). 


\subsection{ESTRATÉGIA E ESTRATÉGIA COMO PRÁTICA SOCIAL (EPS)}

A pesquisa em estratégia tem sido amplamente baseada na tradição microeconômica, que a considera como um processo top-down (da alta gerência para os demais níveis hierárquicos) e deliberado (CARTER; CLEGG; KORNBERGER, 2010). Nesse sentido, a estratégia é comumente vista como a tarefa principal dos gestores seniores, dos CEOs (Chief Executive Officer), como um conjunto de gestores analisando o ambiente ou elaborando um planejamento estratégico deliberado (CARTER; CLEGG; KORNBERGER, 2010).

Essas são justamente algumas das características da perspectiva estratégica clássica. Mais antiga e influente, essa abordagem está centrada na busca pela maximização dos lucros da organização, considerando que a formulação e o controle da estratégia são responsabilidades da alta gerência. Aos gerentes operacionais caberia apenas a implementação da estratégia, que, por sua vez, seria delegada pelos executivos (WHITTINGTON, 2002). Para a abordagem clássica, o ambiente é previsível, os executivos seniores são plenamente racionais e o planejamento e a execução da estratégia são sequencialmente ordenados; o que permite que o planejamento faça sentido em longo prazo (WHITTINGTON, 2002).

Assim, essa perspectiva trata a estratégia como sinônimo de planejamento racional, como uma propriedade das organizações, separando o pensar do agir e o planejamento da execução (WHITTINGTON, 2002; WILSON; JARZABKOWSKI, 2004; WHITTINGTON, 2006). Como consequência, os estudos da área permaneceram no nível macro de análise (das empresas e dos mercados), reduzindo a estratégia a modelos prescritivos ou a algumas variáveis causais, atribuindo pouca relevância para a ação humana (JARZABKOWSKI; BALOGUN; SEIDL, 2007).

No entanto, com a virada em direção ao estudo da prática das ciências sociais (que influenciou as ciências organizacionais e, consequentemente, o estudo da estratégia), alguns pesquisadores passaram a afirmar que a pesquisa em estratégia parecia ter perdido de vista o ser humano, o interesse em relação às práticas dos atores sociais, considerando-a analiticamente restrita ao nível macro (JARZABKOWSKI; BALOGUN; SEIDL, 2007). Desse modo, os estudos assumiram um novo foco de pesquisa, interessando-se também em compreender o processo de formulação e elaboração das estratégias, assim como a implantação das mesmas (WHITTINGTON, 1996; WILSON; JARZABKOWSKI 2004; JARZABKOWSKI; SPEE, 2009).

Já na década de 1970, emergiram as contribuições de Mintzberg e Pettigrew a respeito da abordagem processual da estratégia, segundo a qual as organizações e os mercados são frequentemente fenômenos desordenados, sendo nesse contexto que as estratégias emergem. Assim, a abordagem processual rejeita o racionalismo econômico e o princípio de perfeição dos mercados, destacando os limites cognitivos da ação humana e a micropolítica (os interesses individuais) das organizações. Dessa forma, a estratégia é a combinação da barganha política com a racionalidade limitada e não o produto de cálculos de maximização dos lucros (WHITTINGTON, 2002). A estratégia seria, ainda, um processo contínuo e adaptável, sendo sua formação e implementação inseparáveis. Assim, entende-se que a estratégia pode não preceder a ação, sendo nesse sentido emergente, e não necessariamente deliberada (MINTZBERG; WATERS, 1985).

Diante disso, afirma-se que a abordagem processual se concentra na descrição detalhada (e não na prescrição) da estratégia, preocupando-se em entender como as estratégias realmente se formam nas organizações, e não como as estratégias são formuladas (MINTZBERG; AHLSTRAND; LAMPEL, 2009). Whittington (2007), por sua vez, argumenta que o foco processual investiga como e porquê as coisas evoluem ao longo do tempo, tendendo a se referir à evolução temporal de uma organização em particular ou de conjuntos de organizações. Para o referido autor, certamente há um interesse comum da abordagem processual e da perspectiva da EPS em relação às atividades de elaboração das estratégias, dos episódios da práxis (em relação ao processo de tomada de decisão, por exemplo).

Todavia, o estudo da estratégia sob o enfoque dos estudos baseados em prática (WHITTINGTON, 1996; WHITTINGTON, 2006) pretende e tem potencial para ir além da descrição detalhada das atividades de elaboração das estratégias, dos episódios da práxis, tendo como unidade de análise as práticas sociais (CHIA; MACKAY, 2007). Para a EPS, a estratégia é um fenômeno social como outro qualquer (JARZABKOWSKI; BALOGUN; SEIDL, 2007), ou seja, um conjunto de atividades humanas organizadas (WHITTINGTON, 2007; SCHATZKI, 2005).

Assim, para a perspectiva da EPS, a estratégia é conceituada como uma prática situada, um fluxo de atividades realizadas socialmente. O fazer estratégia (strategizing), por sua vez, compreende essas práticas situadas, assim como as interações e negociações dos múltiplos atores envolvidos (JARZABKOWSKI; BALOGUN; SEIDL, 2007). Whittington (2006) ressalta que enquanto a perspectiva da prática tende a enfatizar o tácito e o 
informal, refletindo suas origens na sociologia da vida cotidiana, a EPS também inclui em sua análise as práticas explícitas, que desempenham um importante papel nas organizações (WHITTINGTON, 2006). Assim, a estratégia é tida como um fenômeno social (assim como outra prática social qualquer), obra da ação humana organizada (SCHATZKI, 2005).

Nesse contexto, estudos recentes, ao assumirem a estratégia como uma prática social, consideram-na como algo que as pessoas fazem e não como um atributo organizacional (VAARA; WHITTINGTON, 2012; SEIDL; WHITTINGTON, 2014), levando em conta também a dimensão micro de análise. Portanto, a estratégia não é dada a priori, e tampouco é exclusiva da alta direção, dos gestores organizacionais. Para a EPS, a estratégia é construída por todos e nas atividades cotidianas de uma organização; ressaltando-se a interação entre o pensar e o agir, entre o planejamento e a execução das atividades estratégicas (WILSON; JARZABKOWSKI, 2004; WHITTINGTON; CAILLUET, 2008; JARZABKOWSKI; SPEE, 2009; GOLSORKHI et al., 2010; WHITTINGTON, 2011).

Um dos primeiros trabalhos a mudar o foco da pesquisa em estratégia para a noção da estratégia como prática social foi o artigo de Richard Whittington (1996). Nesse estudo, uma das preocupações do autor é a elaboração das estratégias, assim como todo o processo de formulação e implantação das mesmas. Os atores sociais, suas ações e interações são trazidos para o centro da análise, uma vez que, para a abordagem da EPS, as estratégias são constituídas no cotidiano organizacional. Assim, quem realiza a estratégia, o que se faz, como se faz, que ferramentas são utilizadas e as implicações dessas ações para a estratégia organizacional passam a ter relevância para a pesquisa (WHITTINGTON, 1996; JARZABKOWSKI; SPEE, 2009).

Como nas teorias da prática, a prática social é a unidade de análise da perspectiva da EPS (WHITTINGTON; CAILLUET, 2008; JARZABKOWSKI; SPEE, 2009; WHITTINGTON, 2011). A estratégia, então, é tida como uma atividade empreendida por indivíduos em seu cotidiano nas organizações e não apenas como um macroatributo das organizações (CARTER; CLEGG; KORNBERGER, 2010). Ainda para a perspectiva da EPS, o fazer estratégia (as microatividades locais) estaria integrado com outros fenômenos sociais (SEIDL; WHITTINGTON, 2014), considerando-se, assim, as dimensão micro e macro de análise.

Todavia, o conceito de estratégia como prática abrange uma ampla gama de atividades, o que dificulta a compreensão do que é ou não estratégia (JARZABKOWSKI; BALOGUN; SEIDL, 2007). Para os autores, a perspectiva da EPS deveria se concentrar nas práticas estratégicas, uma vez que a estratégia é um tipo específico de atividade. Diante disso, o fazer estratégia abarca aquelas atividades que têm consequências para os resultados da organização, mesmo quando essas consequências não são parte de uma estratégia pretendida ou formalmente articulada (JARZABKOWSKI; BALOGUN; SEIDL, 2007; MANTERE, 2005).

\subsubsection{PRÁTICA, PRÁXIS E PRATICANTE}

As teorias da prática consideram a prática social como sua unidade de análise, sendo necessário diferenciá-la dos episódios da práxis, assim como entender que os indivíduos agem como seus "portadores" (RECKWITZ, 2002). Segundo o autor, para que a prática exista, a mesma precisa estar interconectada à práxis e ao praticante. Esses três elementos são considerados interdependentes e mutuamente construídos, não sendo possível reduzir esse "tripé" a apenas uma de suas dimensões (RECKWITZ, 2002).

Nesse âmbito, Whittington (2006) e Jarzabkowski, Balogun e Seidl (2007) sugerem um quadro teórico que relaciona os conceitos de prática, práxis e praticante. Segundo Whittington (2006), o intuito desse quadro é fornecer um vocabulário consistente, uma vez que esses conceitos são frequentemente usados com significados variados. Para tal, tanto Whittington (2006), quanto Jarzabkowski, Balogun e Seidl (2007) baseiamse no trabalho de Reckwitz (2002).

A seguir, os conceitos de prática, práxis, e praticante serão teoricamente analisados e ilustrados por meio de exemplos de estudos empíricos.

A prática social pode ser entendida como o que as pessoas fazem. Entretanto, o termo "prática social" vai além da simples descrição detalhada da ação humana, referindo-se a tipos de comportamento e compreensão rotineiros, que estão ligados à ação humana (práxis) e é realizado por diferentes atores, os praticantes (RECKWITZ, 2002). Entende-se, ainda, que as práticas são "abertas" e melhor compreendidas através de seu dinamismo e movimento. Assim, a prática também inclui atividades irregulares, únicas e que estão em constante mudança (SCHATZKI, 2003).

As práticas são, ainda, um conjunto de ações corporais de "fazer" e "dizer", sendo o não fazer e o não dizer tidos, igualmente, como práticas sociais. "Dizer" não necessariamente envolve a fala, o que pode ser exemplificado quando alguém "diz" algo gestualmente, ao balançar a cabeça, por exemplo. Já o não fazer/dizer 
pode ser percebido quando um indivíduo se recusa a executar/responder algo. Além disso, considera-se que o conjunto de atividades que compõe as práticas é um "nexo organizado de ações". Consequentemente, toda prática social é composta pelas dimensões atividade e organização (SCHATZKI, 2003). Dizer que as práticas são sociais é uma tautologia: a prática é social, uma vez que é um tipo de comportamento e de compreensão rotineiros, que aparecem em diferentes locais e em diferentes pontos do tempo, sendo realizados por diferentes atores (RECKWITZ, 2002).

Quanto à dimensão da prática, Kaplan e Orlikowski (2013) realizam uma investigação fundamentada nas práticas cotidianas dos gestores da empresa CommCorp, um grande fabricante de equipamentos de comunicação. Observou-se que determinadas práticas estratégicas (trabalho temporal) relacionam-se com as interpretações múltiplas e divergentes desses praticantes, o que engloba suas percepções em relação ao passado, presente e futuro das práticas organizativas da CommCorp. As autoras argumentam que o trabalho temporal é central na tomada das decisões estratégicas, uma vez que, por meio dessa prática, os gestores articulam sua decisão e ação com suas interpretações acerca do passado, presente e futuro. Diante disso, considera-se que o fazer estratégia não é o resultado de decisões tomadas por uma organização monolítica, mas sim produzido nas interpretações em curso e nas interações dos múltiplos atores organizacionais ao longo do tempo.

Carrieri et al (2012), por sua vez, realizam uma discussão acerca de como pequenas organizações familiares do mercadão de Madureira (no Rio de Janeiro/RJ) sobrevivem ao longo de quase um século de história. Os autores verificaram a existência de três grandes práticas estratégicas, dentre elas: "o freguês é a gente que faz". A análise dessa prática evidencia a relevância do atendimento ao cliente, havendo no mercadão o estabelecimento de uma relação mais íntima entre os proprietários das lojas e seus clientes.

Em um estudo de caso, Mantere (2005) investiga o fazer estratégia organizacional. Observa-se como as práticas estratégicas (adaptativas ou recursivas) permitem e constrangem a ação dos campeões estratégicos, estando este estudo centrado na análise de microfenômenos. Na formulação da estratégia, notase que há uma tensão entre as práticas adaptativas e recursivas. A abordagem recursiva salienta a previsibilidade das práticas estratégicas (por meio da divulgação de informações, do conhecimento objetivo, de métodos predefinidos de feedback e da operacionalização da estratégia em metas explícitas). As práticas adaptativas, no entanto, compreendem a estratégia de modo dinâmico, como algo construído por meio de interpretações individuais, assim como por meio do improviso entre os estrategistas e executores. Por fim, a análise das práticas, que possibilitam e/ou constrangem a ação dos campeões estratégicos, pode ser considerada a questão chave para o entendimento do porquê de algumas estratégias organizacionais serem bem sucedidas e outras não.

Também em um estudo empírico, Feldman (2004) observou a centralização dos processos de contratação e treinamento de pessoal de residências universitárias, o que traz implicações para os diretores responsáveis por esse processo. Analisaram-se as relações entre recursos, regras (esquemas) e ações, sendo que as relações foram demonstradas mediante a comparação das respostas a incidentes de bulimia (antes e depois da centralização dos processos). Observou-se que a introdução de novas práticas de contratação e treinamento mudou a natureza dos recursos. Com as novas práticas, os diretores perderam sua autoridade central. 0 resultado é que os esquemas para lidar com a bulimia tornam-se mais individuais. Assim, conclui-se que os recursos reforçam os esquemas (regras), os esquemas moldam as ações e as ações demandam recursos (FELDMAN, 2004; WHITTINGTON, 2010).

Em um estudo empírico realizado na cidade de Sydney, Kornberger e Clegg (2011) analisam o processo de elaboração de um projeto estratégico para a mencionada cidade australiana (Sustainable Sydney 2030). Os autores concluíram que o fazer estratégia é uma realização, uma prática sócio-política que visa mobilizar pessoas e legitimar decisões. O fazer estratégia implica desenvolver uma imagem/projeção (normalmente grande) para o futuro, o que constrange e habilita o curso, o desdobramento de ações/atividades imediatas. Nesse contexto, a dimensão estética ${ }^{15}$ da estratégia foi um aspecto crucial para que a opinião pública fosse mobilizada. Por meio

150 termo estética deriva do termo grego aesfhesís, que significa sensação. Diante disso, Strati (1999) defini estética como a faculdade sensorial humana de perceber, por meio dos nossos sentidos (ou seja, por meio do corpo), estímulos (sejam eles visuais, auditivos, olfativos, táteis ou gustativos) enquanto algo prazeroso, repugnante, surpreendente, intrigante, etc. Nós humanos somos "esteticamente atentos" ao contexto social no qual estamos imbricados (STRATI, 1999). É importante ressaltar que a estética está "para além" da percepção física dos sentidos, sendo a expressão de habilidades (muitas vezes tácitas) socialmente construídas, educadas e apuradas (SOARES; BISPO, 2015), uma forma de comunicação diferente da escrita ou da fala (STRATI, 1999). Para Reckwitz (2012), a 
de uma mistura de técnicas de design, colagens, fotografias e esboços, o futuro da cidade foi projetado, criando um imaginário estético atraente. (KORNBERGER, CLEGG; 2011).

O estudo da práxis, por sua vez, foi a motivação original dos primeiros trabalhos da EPS (VAARA e WHITTINGTON, 2012). A práxis da estratégia é o trabalho intraorganizacional necessário para a realização da prática estratégica (WHITTINGTON, 2006). Dessa forma, a práxis trata de episódios (eventos ou atividades), ou sequências de episódios, que ocorrem durante todo o processo do fazer estratégia; episódios nos quais os praticantes interagem (JARZABKOWSKI; BALOGUN e SEIDL, 2007; VAARA; WHITTINGTON, 2012).

O que os praticantes realmente fazem é a práxis da estratégia, ou seja, todas as variadas atividades envolvidas na (re)formulação e (re)implementação da estratégia. Neste sentido, a práxis da estratégia é o trabalho necessário para o fazer estratégia, desde sua elaboração até sua execução (WHITTINGTON, 2006). Todavia, esse é um trabalho difuso e amplo, abarcando a rotina e o que não é rotina, o formal e o informal, as atividades centrais da organização, assim como as periféricas. Todas essas atividades são tidas como episódios da práxis, podendo ser exemplificadas por meio das reuniões formais de um conselho ou pelas conversas informais que fazem parte do cotidiano organizacional (WHITTINGTON, 2006). O que engloba desde uma reunião de planejamento anual da alta gerência, até uma conversa informal que pode ocorrer em um almoço ou na pausa para um simples "cafezinho". Logo, os episódios da práxis são as atividades rotineiras e cotidianas realizadas pelas pessoas nas organizações.

Entretanto, estudar a práxis também significa entender que prática e práxis são mutuamente construídas e que o produto desses pequenos episódios, muitas vezes, não é somente uma decisão, ou não decisão, estratégica; mas também a legitimação, ou não legitimação, de certos atores, escolhas e práticas (RECKWITZ, 2002; VAARA e WHITTINGTON, 2012).

Assim, a práxis compreende a interligação entre as ações dos diferentes atores sociais com as instituições nas quais esses atores estão socialmente, politicamente e economicamente imbricados. A práxis é um conceito integrado e dinâmico, que pode ser operacionalizado em diferentes níveis (do macro institucional ao micro), fluindo através das interações entre esses níveis (JARZABKOWSKI; BALOGUN; SEIDL, 2007). Por exemplo, no nível macroinstitucional, a práxis pode ser estudada como um tipo particular de atividade amplamente difundida (como são a fusão e a aquisição dentro da indústria). Já no micronível, a práxis poderia ser melhor exemplificada observando-se o engajamento de indivíduos, ou grupos de indivíduos, que participam dessas operações de fusão e aquisição (JARZABKOWSKI; BALOGUN; SEIDL, 2007).

É a práxis que faz o praticante, que molda sua capacidade de (re)acessar e (re)implementar as práticas predominantes (WHITTINGTON, 2006). Por exemplo, quando um indivíduo entra em uma comunidade de praticantes, ele aprende gradualmente a tornar-se um membro pleno desse grupo, absorvendo as particularidades dessa comunidade, ou seja, as regras locais e os padrões já internalizados (WHITTINGTON, 2006).

Em relação à práxis, Silva, Carrieri e Souza (2011) realizam um estudo de caso no mercado da Vila Rubim (Vitória/ES), buscando compreender a relação entre os significados das práticas sociais e a criação das estratégias utilizadas pelos comerciantes. Dentre as diversas atividades do mercado, o foco do estudo foi a práxis do comércio de produtos hortifrutícolas, a atividade original do mercado - que atingiu seu auge na década de 1970, quando havia mais de 300 comerciantes. O que os autores descrevem como a "observação do que o cliente quer comprar" e o "incentivo à fidelidade do cliente com diálogo, brindes e venda a crédito" são exemplos de práxis (de atividades diárias) que envolvem os clientes. Além disso, na análise dos dados, os autores observaram que há um duplo movimento nas atividades cotidianas do fazer estratégia: no sentido da manutenção e em prol da mudança de direção das práticas. Segundo os autores, esse duplo movimento das práticas tem diferentes implicações: o reforço ou a transgressão da ordem estabelecida.

Jarzabkowski e Seidl (2008), por sua vez, consideram que algumas das reuniões que ocorrem em uma organização podem ser tidas como episódios estratégicos, como práxis do fazer estratégia. Diante disso, os autores realizam um estudo qualitativo, observando 51 reuniões de três universidades. Essas reuniões são analisadas em relação ao seu potencial de estabilizar ou desestabilizar as orientações estratégicas existentes nas universidades, considerando-se que a proposição de variações pode gerar, cumulativamente, mudanças nas orientações estratégicas. Os autores propõem que, através da melhor compreensão das microestruturas,

estética, enquanto um nexo entre percepções e afetos, é uma das dimensões básicas das práticas e da vida social, um traço antropológico dos seres humanos. Assim, a dimensão estética da realidade assume um papel ativo na constituição da vida social e dos processos organizativos. 
seria possível entender como a atividade estratégica emerge.

Ainda em relação ao estudo de Carrieri et al (2012), percebe-se que a prática estratégica “o freguês é a gente que faz" relaciona-se com determinados episódios da práxis. Uma vez que a relação entre os proprietários das lojas e seus clientes pode ser evidenciada por meio de visitas eventuais. Por exemplo, segundo um dos entrevistados "[...] se tratar bem, ele volta. Aí, você vai fazer uma visita, se é pai-de-santo, alguma coisa, vai no barracão dele, alguma coisa" (CARRIERI et al, 2012, p. 212). Diante disso, os autores ressaltam que essa práxis é estabelecida visando à fidelização do cliente.

Quanto ao praticante, conforme já mencionado, a literatura sobre estratégia é tradicionalmente dominada por conceitos que a compreendem como um processo top-down, no qual a formulação é separada da implementação, cujo foco analítico está na tomada de decisão por parte da alta gerência (JARZABKOWSKI; BALOGUN e SEIDL, 2007). Todavia, ao se referir aos praticantes, a perspectiva da EPS trata de todos os atores sociais que estão envolvidos no processo do fazer estratégia, considerando não somente o alto escalão (top managers) das grandes organizações (VAARA e WHITTINGTON, 2012).

Isso não significa afirmar que a alta administração deva ser ignorada, uma vez que ainda há muito o que aprender a partir do estudo desses atores como participantes do fazer estratégia e não somente como seus formuladores (JARZABKOWSKI; BALOGUN e SEIDL, 2007). Entretanto, para a perspectiva da EPS, a média gerência e os níveis hierárquicos mais baixos também são importantes atores no processo de fazer estratégia, apesar de os mesmos não terem, necessariamente, um papel formal como estrategistas. Os atores externos, que estão fora da estrutura formal da organização, mas moldam indiretamente sua estratégia, também são considerados praticantes (JARZABKOWSKI; BALOGUN e SEIDL, 2007).

Assim, os praticantes do fazer estratégia não são apenas os executivos seniores para quem a estratégia é o núcleo de seu trabalho; mas todos os envolvidos nas práticas estratégicas, ou seja, todos aqueles que fazem o trabalho de (re)planejamento, (re)modelagem e execução das atividades estratégicas (WHITTINGTON, 2006). Os praticantes estão envolvidos, influenciam e são influenciados pela estratégia organizacional, uma vez que fazem parte, encontram-se imersos em um contexto social. Por isso, os praticantes são seres sociais e não simples indivíduos e a prática (o fazer estratégia) é social e não individual (RECKWITZ, 2002; JARZABKOWSKI; BALOGUN e SEIDL, 2007; VAARA e WHITTINGTON, 2012).

Dessa forma, características sociais, políticas, retóricas, culturais e até mesmo o gênero influenciam o modo como cada praticante age como portador da prática. Esses elementos, entretanto, compõem a prática na qual o indivíduo participa, não sendo vistos como suas características (RECKWITZ, 2002; JARZABKOWSKI; BALOGUN e SEIDL, 2007; VAARA e WHITTINGTON, 2012). Assim, como para as teorias da prática, para a EPS os praticantes são vistos como a conexão crítica, o elo entre a práxis e as práticas organizacionais e extraorganizacionais (RECKWITZ, 2002; WHITTINGTON, 2006).

Quanto aos praticantes, Jarzabkowski, Spee e Smets (2013) abordam como os gerentes de empresas de resseguro usam artefatos materiais (fotografias, mapas, pacotes de dados, planilhas e gráficos) na elaboração de atividades estratégicas, mais especificamente, na avaliação de ofertas de resseguro. Os autores justificam a seleção dos gestores como praticantes pelo fato de o setor de resseguros requerer serviços profissionais específicos, em que os gerentes desempenham um papel significativo na formação da estratégia de suas organizações.

Baunsgaard e Clegg (2013), por sua vez, examinaram a integração interfuncional nos processos de inovação de produtos de uma pequena empresa do setor de construção da Dinamarca. Foi observado que o proprietário da empresa e o CEO não estavam dispostos a alocar recursos em pesquisas de marketing, pois consideravam que esse investimento poderia enfraquecer suas posições frente aos departamentos de pesquisa e desenvolvimento (P\&D) e produção. Evidencia-se a importância do poder e da política, assim como dos praticantes (estrategistas), para a compreensão dos processos de inovação. Diante disso, os autores argumentam que os membros da organização (praticantes) devem ser vistos também como membros de comunidades de identidade profissional. Considera-se que as organizações são arenas ideológicas e políticas, onde há interesses divergentes em disputa.

Já Tureta e Lima (2011) observam a existência de praticantes externos à rede organizacional estudada, destacando que os representantes da empresa de marketing, que assessoravam a rede, gerenciavam a marca da empresa. Apesar de não deterem uma posição formal na hierarquia da organização, os representantes são tidos como atores ativos nas atividades estratégicas, no fazer estratégia. 
Ainda em relação ao estudo de Mantere (2005), considera-se que não apenas os gestores seniores são estrategistas (praticantes do fazer estratégico), uma vez que os indivíduos em todos os níveis organizacionais podem decidir se eles tentarão ou não agir como "campeões estratégicos". Campeões estratégicos são indivíduos que tentam influenciar questões estratégicas maiores do que as suas próprias responsabilidades operacionais imediatas, buscando afetar opiniões e/ou atividades de superiores, pares e subordinados e mudar a organização e/ou seus sistemas a fim de garantir recursos. Assim, ser campeão estratégico é uma posição social e não funcional.

É interessante notar que a dependência dos praticantes em relação às práticas não é necessariamente passiva, já que a práxis também pode ser uma performance improvisada; tendo os praticantes a possibilidade de mudar as práxis nas quais estão envolvidos (WHITTINGTON, 2006).

Diante disso, apesar de as práticas também serem definidas como um padrão de ação que é reproduzido (RECKWITZ, 2002), as mesmas não são imutáveis. Pelo contrário, as práticas são diversas e variáveis, sendo (re)combinadas e alteradas de acordo com seu uso pelos praticantes. Diante disso, ao se estudar como a EPS é construída, um dos interesses de pesquisa é compreender como a mobilização das práticas se altera ao longo do tempo e como as práticas ajudam a moldar a práxis (JARZABKOWSKI; BALOGUN e SEIDL, 2007). Para Schatzki (2003), as práticas sociais são abertas e melhor compreendidas através de seu dinamismo e movimento. Assim, a prática também inclui atividades irregulares e únicas, que estão em constante mudança.

Conforme mencionado, os três elementos da prática estratégica (do fazer estratégia) são interdependentes e mutuamente construídos, não sendo possível reduzir esse tripé a apenas uma de suas dimensões (RECKWITZ, 2002). O fazer estratégia ocorre no nexo, na intersecção entre a práxis, a prática e o praticante (JARZABKOWSKI; BALOGUN e SEIDL, 2007).

\subsubsection{LIMITAÇÕES DA PERSPECTIVA DA EPS}

Conforme mencionado, a EPS apresenta-se como uma das alternativas às perspectivas estratégicas tradicionalmente baseadas na microeconomia, que consideram a estratégia como sinônimo de planejamento racional, como uma propriedade das organizações, separando o pensar do agir, e o planejamento da execução (WHITTINGTON, 2002; WILSON; JARZABKOWSKI, 2004; WHITTINGTON, 2006). Apesar de tratar a estratégia como uma prática social, consideram-na como algo que as pessoas fazem em seu dia a dia nas organizações, e não como um atributo organizacional, a abordagem da EPS encontrou dificuldades em integrar o fazer estratégia com análises mais amplas, em relacionar os diferentes níveis de análise, concentrando-se em abordagens microanalíticas (WHITTINGTON, 2006; VAARA; WHITTINGTON, 2012; SEIDL; WHITTINGTON, 2014).

Segundo Nicolini (2013), a grande contribuição da primeira geração de pesquisadores da abordagem da EPS foi revelar como os gestores, de fato, realizam o fazer estratégia. Todavia, o foco da maioria das pesquisas empíricas esteve centrado na descrição detalhada do cotidiano dos estrategistas, assim como dos processos internos das organizações. Dessa forma, analisaram-se, majoritariamente, os episódios da práxis, havendo, até mesmo, certa admiração em relação a reuniões, workshops, sessões de tomada de decisão, e outras microatividades ligadas às habilidades individuais dos gestores seniores. Além disso, o foco nas microatividades fez com que a EPS tratasse de modo intercambiável, ou seja, quase como sinônimos, os termos atividade, prática e processo. Ainda segundo o autor, a prática social foi tratada como um epifenômeno, sendo reduzida à ação e/ou à intenção dos agentes individuais, estando a abordagem da EPS centrada no ator e nos microepisódios da práxis.

A abordagem da prática teria potencial para ir além da humanização do campo da gestão estratégica, não se contentando simplesmente em "abrir a caixa preta" das organizações, ou seja, em revelar como os gestores realizam seu fazer estratégico (NICOLINI, 2013). Ao lançar mão da lente da prática, os estudos que adotam a perspectiva da EPS deveriam se preocupar mais em definir o termo "prática social", guiando-se (teórica e empiricamente) por essa definição (CHIA; MACKAY, 2007). De modo complementar, Schatzki (2012, p. 14) afirma que:

[...] a wide variety of theorists today use the expressions "practices" or "social practices" in the absence of an elaborated or even explicit conception of practices. These expressions are also often used almost unreflectively, in a way that suggests that the writer or speaker believes that his/her subject matter is a form of, or rooted in, human activities. In this way, a vague, unarticulated sense of the first two commonalities that delimit practice theory has disseminated far beyond its 
imprecise shores and become commonplace in contemporary social thought.

A virada da estratégia em direção ao estudo da prática figura-se como uma alternativa em relação à abordagem processual, tendo potencial para reformular o modo como os fenômenos agência e estrutura são tratados, o que, inclusive, permitiria aos pesquisadores superar (ou, simplesmente, ignorar) a dicotomia presente nas ciências sociais, em geral, e na pesquisa em estratégia, em particular - entre os níveis micro e macro (CHIA; MACKAY, 2007).

Dessa forma, a virada para a prática dos estudos em estratégia ainda estaria incompleta (WHITTINGTON, 2006; VAARA e WHITTINGTON, 2012), uma vez que a abordagem da EPS apresenta-se centrada em análises intra e extraorganizacionais ainda pouco integradas, no nível intraorganizacional, ou sobre os efeitos agregados das microatividades. Nesse âmbito, considera-se que o potencial da perspectiva da estratégia como prática ainda não foi totalmente explorado (WHITTINGTON, 2006; VAARA e WHITTINGTON, 2012). Assim, faltaria à grande parte dos estudos que se baseiam na perspectiva da EPS integrar o fazer estratégia (as microatividades locais) com outros fenômenos sociais (SEIDL; WHITTINGTON, 2014).

Diante disso, a EPS estaria sofrendo de microisolacionismo empírico (empirical micro-isolationism), havendo nos estudos uma grande tendência de se explicarem as atividades locais em seus próprios termos (SEIDL; WHITTINGTON, 2014), desconsiderando-se que os praticantes realizam as práticas em um contexto, que molda o que faz sentido para os atores sociais, que torna possível e constrange as opções de ação dos indivíduos (SCHATZKI, 2003). Apesar de haver algum reconhecimento das interações entre as organizações e o mercado, a tendência ao microisolacionismo faria com que as organizações fossem tratadas como recipientes isolados dos macrofenômenos sociais (SEIDL; WHITTINGTON, 2014).

O potencial (ainda pouco explorado) da perspectiva da EPS estaria justamente na habilidade de explicar como o fazer estratégia relaciona-se com as práticas organizacionais e sociais (VAARA; WHITTINGTON, 2012). O que possibilitaria uma compreensão mais integrada da prática estratégica, como uma atividade que se desdobra no cotidiano organizacional, assim como um fenômeno que se estende para além das fronteiras das organizações, podendo influenciar (e ser influenciado) o campo organizacional e a sociedade (WHITTINGTON, 2006).

De modo complementar, a prática social se refere às atividades situadas dos indivíduos (nível micro de análise) e às práticas socialmente definidas (nível macro) em relação às quais os indivíduos baseiam suas ações. Assim, a estratégia pode ser definida em vários níveis sociais (micro e macro), sendo possível relacionar contextos mais amplos com microações (JARZABKOWSKI; BALOGUN; SEIDL, 2007).

A prática estratégica, então, é tida como uma prática complexa, flexível e polivalente; podendo incluir, excluir, legitimar, deslegitimar e, potencialmente, transformar conceitos previamente existentes na organização, assim como a própria prática organizacional. Ressalta-se, assim, a importância das práticas institucionalizadas localmente, já inseridas na cultura e na rotina organizacional (VAARA; WHITTINGTON, 2012).

Nesse âmbito, para que a potencialidade da abordagem da EPS possa ser explorada é necessário ir além da organização (da organização para o campo organizacional), aprofundando-se o argumento de que as práticas têm potencial para afetar as estruturas sociais que as constrangem (RECKWITZ, 2002). Assim, a estratégia pode e deve ser conceituada como um campo ou sistema social (VAARA; WHITTINGTON, 2012). Segundo os autores, tal entendimento mudaria, por si só, o foco de atenção dos estudos sobre EPS para a interdependência entre o fazer estratégia (a atividade diária organizacional, suas rotinas e improvisos) e o contexto macrossocial (como tais práticas são produzidas, reforçadas e modificadas), ressaltando-se, assim, que o fazer estratégia está imbricado nesse contexto. Esse enfoque teórico estenderia as contribuições das abordagens empíricas, indo além da microanálise do fazer estratégia.

Nesse âmbito, Whittington (2007) sugere que a dimensão "profissão" seja articulada com os elementos práxis, prática e praticante (JARZABKOWSKI; BALOGUN e SEIDL, 2007; WHITTINGTON, 2006), referindo-se à estratégia como um campo institucionalizado. Segundo Whittington (2007, p. 1580):

[...] I introduce this 'fourth $P$ ' to underline the importance of strategy as a specialized institutional field in which we - as strategy researchers and teachers - are implicated as well. Strategy is a kind of profession like law, medicine or journalism (with its fringe of part-timers and transients, the closest analogy): it is an occupational group with a collective identity and a set of connections that goes far beyond particular organizations [...]. 
Assim, reconhece-se que a prática estratégica, assim como as outras práticas sociais, está profundamente enraizada, imbricada em seu contexto (embeddeness). Logo, o fazer estratégia está em sintonia com um conjunto mais amplo de conexões e relações, considerando-se que o contexto macrossocial permeia os praticantes e as práticas (WHITTINGTON, 2007). Dessa forma, conforme esquema 1, pode-se afirmar que a estratégia como prática (o fazer estratégia) e suas dimensões - a práxis, a prática e o praticante (JARZABKOWSKI; BALOGUN e SEIDL, 2007) -, estão imbricadas em um contexto mais amplo.

Esquema 1 - Estratégia como prática imbricada no contexto macrossocial

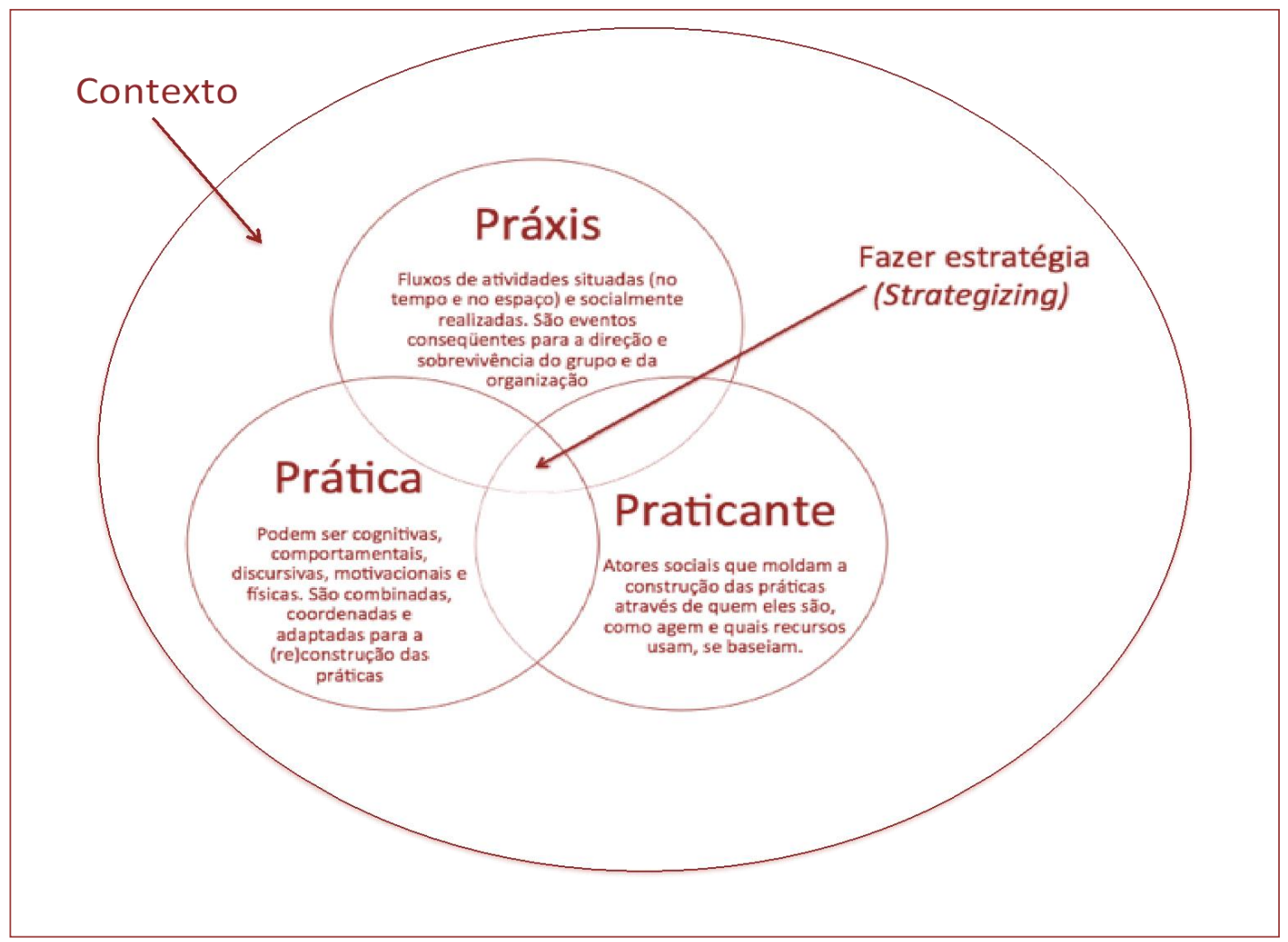

Fonte: Jarzabkowski, Balogun e Seidl (2007), Whittington (2007).

Nota: Adaptado pelo autor.

Por fim, acredita-se que há uma lacuna na discussão do fenômeno da estratégia no âmbito organizacional (VAARA; WHITTINGTON, 2012; SEIDL; WHITTINGTON, 2014) e que o entendimento de que o fazer estratégia está imbricado em contextos mais amplos ajudaria a integrar a prática estratégia (as microatividades locais) a outros fenômenos sociais, a superar o dualismo, a dicotomia entre agente e estrutura, entre estabilidade e mudança, reconhecendo-se que esses fenômenos não são independentes, e sim mutuamente constituídos, havendo uma relação recursiva, reflexiva entre eles (SEIDL; WHITTINGTON, 2014).

\subsection{ARTICULANDO A EPS COM A EPISTEMOLOGIA DE SCHATZKI}

Autores como Nicolini (2013) consideram que muito seria obtido se os estudiosos das práticas apreciassem as semelhanças e as diferenças entre as teorias da prática, e se, especialmente, fizessem com que essas diferenças trabalhassem em prol de suas pesquisas e dos estudos baseados em prática como um todo. É nesse sentido que diferentes perspectivas baseadas na prática social poderiam ser articuladas de modo a se complementar. Diante disso, entende-se que as abordagens da EPS pode ser articuladas com a epistemologia da prática de Theodore Schatzki.

Assim, o fazer estratégia pode ser interpretado como uma prática social, um nexo de atividades humanas organizadas e arranjos materiais situado em um dado contexto. Os estrategistas seriam os praticantes dessas práticas, sendo os episódios da práxis exemplos de atividades em torno das quais o fazer estratégia se 
desdobra.

Além disso, ao se lançar mão das contribuições de Schatzki para a análise do fazer estratégia, pode-se afirmar que esse é um fenômeno social que "acontece", que é realizado (performance) pelos estrategistas, desdobrando-se no cotidiano organizacional, em um dado contexto e ao longo do tempo.

O acontecimento do fazer estratégia organiza-se em torno dos elementos regras, entendimentos e teleoafetividade, assim como dos arranjos materiais (artefatos, organismos e indivíduos) que dão suporte a essa prática (SCHATZKI, 2006). Os elementos regras, entendimentos e teleoafetividade são incorporados pelos praticantes (ou seja, pelos estrategistas) nos processos de socialização. Os estrategistas, por sua vez, incorporam e carregam consigo diferentes "microversões" desses elementos, uma vez que cada praticante tem histórias de vida, habilidades e atitudes (background) distintas.

É possível argumentar, ainda, que durante o acontecimento do fazer estratégia pode haver uma sobreposição de práticas ou de atividades que compõem essa prática, uma vez que não há fronteiras rígidas separando as práticas ou as atividades. Assim, uma ação de "fazer" ou "dizer" pode pertencer a mais de uma prática ou atividade (SCHATZKI, 2003).

Além disso, entende-se a estratégia como um campo ou sistema social, havendo uma relação de interdependência entre o fazer estratégia (a atividade diária organizacional, suas rotinas e improvisos) e o contexto macrossocial (como tais práticas são produzidas, reforçadas e modificadas), ressaltando-se que o fazer estratégia está imbricado em um dado contexto (VAARA; WHITTINGTON, 2012).

Logo, assim como outras práticas sociais quaisquer, o fazer estratégia está situado no tempo e no espaço, ou seja, em um dado contexto (SCHATZKI, 2001). Dessa forma, ressalta-se que os fenômenos que povoam o campo organizacional devem ser (re)conceitualizados como fenômenos sociais quaisquer (SCHATZKI, 2005). Assim, para Schatzki, os fenômenos sociais não possuem uma natureza ou essência distinta que os diferencie (sendo uma complexa malha de práticas, de atividades organizadas e arranjos materiais), podendo estar organizados em menor ou maior escala, como um fractal.

É essa organização que iṣ̌̂̉ppode passar uma "sensação" de agência e/ou de estrutura (SCHATZKI, 2002, 2005; NICOLINI, 2013), de que há micropráticas e estruturas macroinstitucionais, conforme é ressaltado nos estudos que lançam mão da perspectiva da EPS. O fato de os elementos (regras, entendimentos e teleoafetividade) que organizam as práticas serem incorporados pelos indivíduos nos processos de

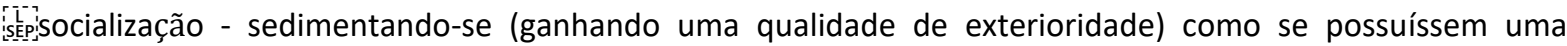
realidade própria - também contribui para essa "sensação" (NICOLINI, 2013). Além disso, pode-se afirmar que a "sensação" de estrutura (NICOLINI, 2013) engloba também as estruturas persistentes das práticas, assim como seus arranjos materiais duradouros. Assim, o que persiste é a memória da prática, a organização das práticas, e não a "estrutura" como um nível para além dos fenômenos sociais.

Dessa forma, entende-se que as contribuições de Schatzki estão para além da articulação entre os âmbitos micro-organizacionais (motivação inicial da pesquisa sobre EPS) e macroinstitucionais, uma vez que o fazer estratégia não possui uma natureza ou essência distinta (nem micro, nem macro), devendo ser (re)conceitualizados como um fenômeno social como outro qualquer. 


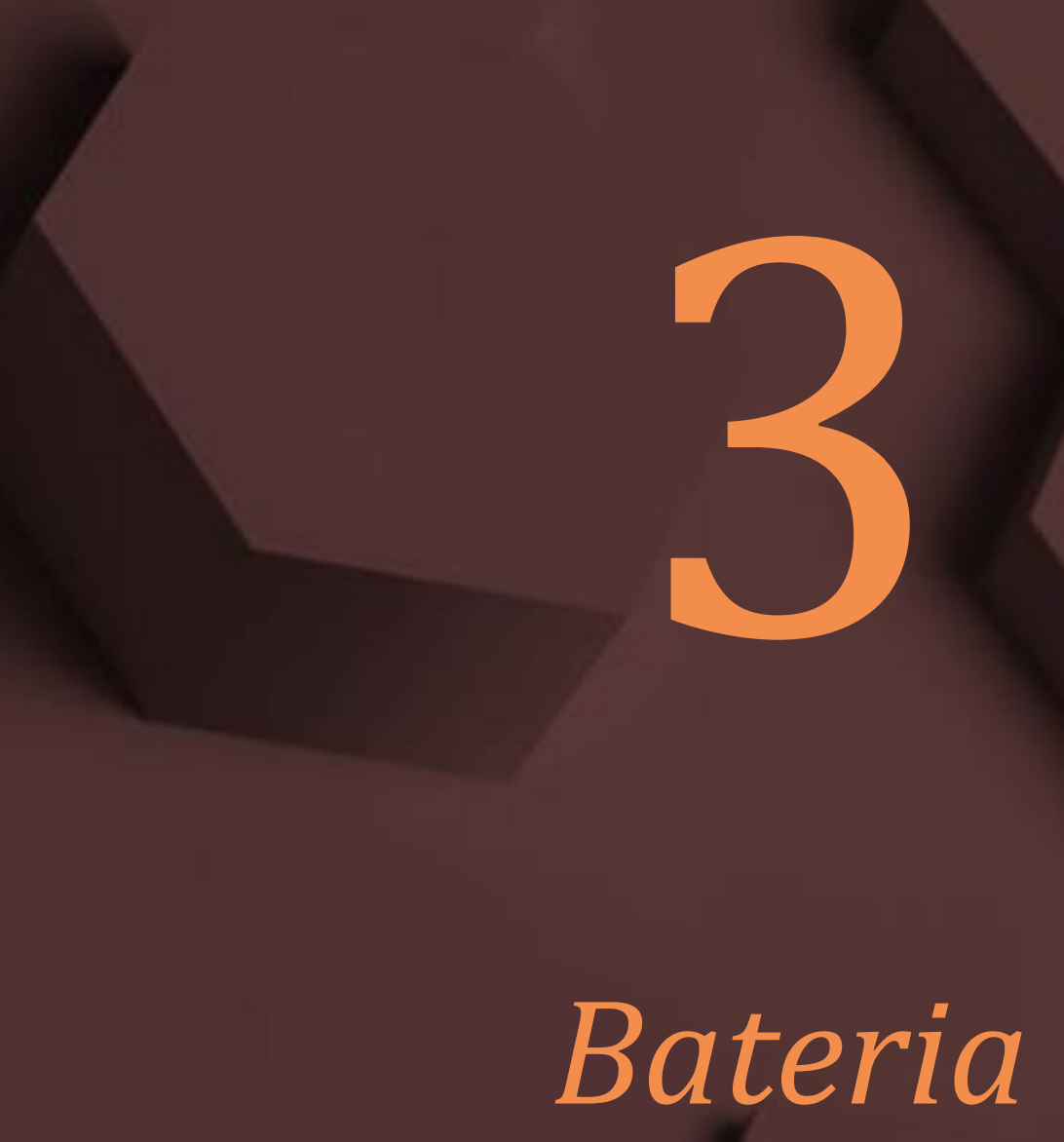




\section{BATERIA}

A seguir, apresenta-se a metodologia adotada nesta pesquisa, que se desdobrou por meio da observação participante, entrevistas exploratórias e semiestruturadas, pesquisa documental e fotografias. Ao final do capítulo, relata-se o acesso ao campo, destacando-se que, no decorrer da pesquisa de campo, a observação emergiu como a principal forma de acesso às práticas empregadas na produção do desfile carnavalesco ${ }^{16}$.

\subsection{O DESDOBRAMENTO DA PESQUISA DE CAMPO}

Estudos qualitativos são interpretativos, sendo que o investigador, em geral, envolve-se em uma experiência intensiva com os participantes. Essas características permitem ao pesquisador social relatos detalhados dos processos e nuances da investigação, o que está alinhado com o objetivo deste trabalho e justifica o uso desse tipo de estudo na pesquisa (CRESWELL, 2007).

A pesquisa de campo teve início no final do mês de outubro de 2014 e término no início do mês de março de 2015. O acesso ao campo se deu em outubro, no entanto a pesquisa começou a acontecer de modo sistemático a partir de dezembro.

Ressalta-se que esta pesquisa está delimitada à análise do processo de realização, à produção do desfile carnavalesco, uma vez que as escolas de samba são julgadas pela concepção e pela realização do desfile de carnaval. Isso pode ser observado pela subdivisão dos quesitos de julgamentos: O quesito samba-enredo, por exemplo, é apurado pelo conteúdo da letra do samba e por sua melodia (CAVALCANTI, 1994). Assim sendo, acompanhou-se o processo de produção das fantasias e dos carros alegóricos, reuniões, ensaios gerais, de rua e técnico, assim como o desfile carnavalesco da agremiação.

Ressalto que utilizarei o recurso da narrativa em primeira pessoa para descrever minha experiência de campo (CLIFFORD, 2008), destacando minha presença como pesquisadora durante a prática do fazer pesquisa. É por meio destes relatos que o pesquisador "dá sentido ao vivido", traçando relações e remontando os acontecimentos observados, para, então, interpretar seus significados (DALLA CHIESA; FANTINEL, 2014).

\subsection{COLETANDO OS DADOS}

Na pesquisa social o pesquisador lida com problemas que são caracterizados por sua complexidade. 0 estudo dessa complexidade social, por sua vez, suscita uma necessidade metodológica, demandando uma variedade de instrumentos de coleta de dados (MONTERO, 1995; BAUER; GASKELL; ALLUM, 2002). Diante disso, a cobertura adequada dos acontecimentos sociais exige um pluralismo metodológico e de dados. Assim, considerando o caráter complementar e mutuamente enriquecedor dos diferentes instrumentos de coleta de dados, este estudo lança mão da triangulação da observação com outras fontes de dados, o que diferencia uma variedade de evidências (STAKE, 1994).

Diante disso, realizei este estudo por meio de observação participante com inspiração etnográfica (com descrição densa das observações registradas em diários de campo), entrevistas exploratórias e semiestruturadas em profundidade, documentos da agremiação e da Liga das Escolas de Samba do ES (LIESES) e imagens/fotografias.

Durante meu trabalho como pesquisadora, busquei observar e registrar em meu diário de campo os comportamentos cotidianos do grupo (dos integrantes da agremiação), dos habituais aos considerados novos (DALLA CHIESA; FANTINEL, 2014). Tal registro abarcou opiniões, comentários e palavras dos "nativos", sendo meu intuito compreender o ponto de vista, a visão de mundo dos pesquisados (MALINOWSKI, 1978), a lógica contextual que orienta a vida do grupo estudado (BOAS, 2004).

Assim, a coleta de dados foi feita tomando como referência as observações de Schatzki (2006), que considera que as organizações são fenômenos sociais que acontecem, ou seja, estão em constante estado de

\footnotetext{
16 A bateria de uma escola de samba é formada por instrumentos de percussão - como surdos, repique, chocalho, tamborim, cuíca, agogô, reco-reco, pandeiro e prato - sendo conduzida pelo Mestre de Bateria. Durante o desfile carnavalesco, a bateria acompanha o canto dos intérpretes do samba-enredo, conduzindo o ritmo, a evolução/performance dos integrantes da escola. No quesito bateria é avaliada a regularidade, a sustentação da cadência dos instrumentos, que também devem estar em consonância com o samba-enredo.
} 
(re)constituição. Dessa forma, para compreender e analisar o processo organizativo, o pesquisador deve vivenciar seu acontecimento na medida em que ele se desdobra. Considero, ainda, que as práticas em si somente podem ser acessadas por meio da observação, uma vez que as entrevistas tornam acessíveis apenas os relatos dessas práticas (FLICK, 2004).

\subsubsection{OBSERVAÇÃO}

Para que o processo de produção do desfile carnavalesco pudesse ser analisado, acompanhei sistematicamente o cotidiano da escola de samba durante os meses de dezembro de 2014, janeiro e fevereiro de 2015, em diferentes espaços/contextos organizacionais: Ateliês (onde as fantasias foram confeccionadas), barracão pesado (onde os carros alegóricos foram produzidos), sede (onde reuniões aconteceram) e quadra da escola (onde reuniões e ensaios ocorreram), ruas do bairro (onde se deu o ensaio de rua), sambão do povo (local de realização do ensaio técnico e do desfile carnavalesco) e ginásio de esportes do clube Álvares Cabral (local de realização da apuração do desfile carnavalesco).

Ao todo foram 35 observações, 82 horas e 30 minutos de observação e 52.457 palavras em meu diário de campo. Minha última observação foi realizada no dia 10 de fevereiro de 2015, no dia da apuração do desfile carnavalesco de Vitória/ES.

No decorrer da pesquisa de campo, a observação emergiu como minha principal forma de acesso às práticas empregadas na produção do desfile carnavalesco, e o campo, que permitiu minha observação, também exigiu minha participação, algo que inicialmente não foi planejado. Assim, apesar de a observação (e não a participação) ter sido pensada como uma das técnicas de coleta de dados desta pesquisa, no campo ocorreram situações em que não pude me furtar de participar ativamente da rotina da escola.

A observação possibilitou presenciar in loco o desdobramento das práticas organizativas da escola de samba, além disso, as informações coletadas foram acessadas a partir de minha inserção nesses espaços/contextos organizacionais. No decorrer da pesquisa, participei de atividades que alteraram minha identidade no campo (de pesquisador para integrante da escola) e minha observação (de não participante para participante).

Assim, assumo esta pesquisa como uma observação participante, uma vez que, além de realizar observações sistemáticas, executei "com minhas próprias mãos" várias das atividades desempenhadas pelos pesquisados em sua rotina de trabalho na escola de samba. Além disso, o fato de eu estar presente -na quadra, nos ateliês, no barracão, na sede da escola, nas ruas do bairro d e no sambão do povo-, de alguma maneira, já me fez participar (SANTOS, 2014) do acontecimento da agremiação, das atividades desempenhadas por seus integrantes e foliões.

A observação participante é uma das técnicas para a obtenção de dados com profundidade, cuja paternidade cabe a Bronislaw Malinowski. A observação participante requer que o pesquisador mergulhe no cotidiano de um determinado grupo social, de uma determinada cultura, apreendendo o maior número possível de perspectivas, aculturando-se, ou seja, assimilando as categorias que ordenam o universo cultural investigado. Isso requer que o pesquisador ganhe a confiança das pessoas do grupo estudado, aproximando-se com sensibilidade, empatia e flexibilidade, reconhecendo o momento de perguntar e de calar (YANOW, 2012), o que permite desvendar as relações sociais, a construção dos significados compartilhados por um determinado grupo social (CAVEDON, 2003), os imponderáveis da vida real (MALINOWSKI, 1978).

Vale ressaltar que, segundo Scott (1972), não há uma divisão estanque entre observação participante e não participante, sendo a dicotomia atribuída aos diferentes mecanismos de observação, na verdade, um continuum.

\subsubsection{ENTREVISTAS}

As entrevistas foram outra fonte de dados. As mesmas foram realizadas durante e após a observação, entre os meses de janeiro de 2015 e março de 2015, sendo os sujeitos de pesquisa selecionados de acordo com seu tempo como integrante da escola (que deveria ser igual ou superior a dez anos). A escola de samba foi campeã do carnaval de Vitória/ES nos anos de 2006, 2007, 2008 e 2009, o que justifica a importância de se entrevistar atores que são integrantes da escola há pelo menos dez anos (ou seja, desde 2006). 
As entrevistas foram divididas em dois grupos: Entrevistas exploratórias e entrevistas em profundidade com roteiro semiestruturado. Ao todo foram realizadas 24 entrevistas, sendo nove exploratórias e 15 em profundidade.

As entrevistas exploratórias tinham o intuito de realizar um contato inicial com o campo, com os integrantes da escola de samba, assim como tirar dúvidas iniciais sobre o objeto de estudo e a produção do desfile carnavalesco. O roteiro semiestruturado das entrevistas em profundidade, por sua vez, foi adaptado de acordo com as particularidades de cada um dos sujeitos. Além disso, durante as entrevistas, busquei não interferir na ordenação das narrativas (DE OLIVEIRA; CAVEDON, 2013). Em todas as 15 entrevistas semiestruturadas usei um gravador digital. Ao todo foram 39 horas e 40 minutos de entrevistas (exploratórias e em profundidade), com duração média de 1 hora e 39 minutos. Para que a análise dos dados possa ser realizada, as entrevistas gravadas foram transcritas.

Conforme mencionado, os sujeitos foram selecionados após a inserção no campo, de acordo com seu "tempo como integrante da escola". Apesar de integrarem a escola de samba há menos de um ano, alguns "atores-chave", como o carnavalesco e os coreógrafos da comissão de frente, também foram selecionados. Esses atores são diretamente responsáveis por três dos dez quesitos de julgamento do desfile carnavalesco (fantasia, alegoria e comissão de frente), daí sua importância na produção do desfile.

Para que a identidade dos entrevistados seja preservada, os mesmos serão identificados por números, conforme Quadro 3:

Quadro 1 - Sujeitos entrevistados

\begin{tabular}{|c|c|c|c|}
\hline Entrevistado & Cargo/Função na escola & Duração da entrevista & Tipo de Entrevista \\
\hline 1 & Diretora adjunta de carnaval & 2 horas & Exploratória \\
\hline 2 & Diretor de carnaval & 30 minutos & Exploratória \\
\hline 3 & Carnavalesco & 1 hora & Exploratória \\
\hline 4 & Destaque $^{17}$ e estilista 1 & 1 hora & Exploratória \\
\hline 5 & Fornecedor do Rio de Janeiro & 2 horas e 30 minutos & Exploratória \\
\hline 6 & Destaque e estilista 2 & 1 hora 15 minutos & Exploratória \\
\hline 7 & $\begin{array}{l}\text { Coreógrafos } \\
\text { da comissão de frente }\end{array}$ & 50 minutos & Exploratória \\
\hline 8 & $\begin{array}{l}\text { Integrante da velha guarda, responsável pela } \\
\text { venda das fantasias comerciais }\end{array}$ & 40 minutos & Exploratória \\
\hline 9 & Estilista e ex-carnavalesco da escola & 1 hora e 20 minutos & Exploratória \\
\hline 10 & Destaque e estilista 1 & 2 horas e 13 minutos & Semiestruturadas \\
\hline 11 & Destaque e estilista 2 & 1 hora e 37 minutos & Semiestruturadas \\
\hline 12 & Diretora adjunta de carnaval & 2 horas 34 minutos & Semiestruturadas \\
\hline 13 & $\begin{array}{l}\text { Diretor adjunto de carnaval e diretor de } \\
\text { comunicação }\end{array}$ & 2 horas e 55 minutos & Semiestruturadas \\
\hline 14 & Diretor adjunto de harmonia & 1 hora e 5 minutos & Semiestruturadas \\
\hline 15 & Mestre de bateria & 2 horas e 12 minutos & Semiestruturadas \\
\hline 16 & $\begin{array}{l}\text { Coordenadora das alas das baianas e das } \\
\text { crianças }\end{array}$ & 1 hora e 20 minutos & Semiestruturadas \\
\hline 17 & $\begin{array}{l}\text { Coreógrafos } \\
\text { da comissão de frente }\end{array}$ & 1 hora e 35 minutos & Semiestruturadas \\
\hline 18 & Estilista e coreógrafo de ala & 1 hora e 41 minutos & Semiestruturadas \\
\hline 19 & Enredista $^{18}$ & 2 horas e 7 minutos & Semiestruturadas \\
\hline 20 & Compositora & 2 horas & Semiestruturadas \\
\hline 21 & Diretor de carnaval & 1 hora e 49 minutos & Semiestruturadas \\
\hline 22 & Escultor (carros alegóricos) & 1 hora e 56 minutos & Semiestruturadas \\
\hline 23 & Carnavalesco & 2 horas e 40 minutos & Semiestruturadas \\
\hline 24 & Estilista & 51 minutos & Semiestruturadas \\
\hline
\end{tabular}

Fonte: Elaborado pela autora

\footnotetext{
17 Pessoas que desfilam com fantasias luxuosas nos pontos mais altos dos carros ou no chão, em frente as alas. Nos carros há um destaque central (cuja fantasia é a mais luxuosa) e alguns semi-destaques.

18 Autor do enredo
} 
O uso de entrevistas qualitativas permite que o pesquisador compreenda o mundo da vida de seu(s) respondente(s), explorando as relações entre os atores e seus contextos sociais específicos (BAUER; GASKELL; ALLUM, 2002).

\subsubsection{DOCUMENTOS}

A pesquisa documental, por sua vez, conta com samba alusivo da escola, sambas-enredos dos últimos dez anos, enredos de 2012 a 2015 e regulamento do carnaval 2015, setorização do desfile carnavalesco de 2015, script do desfile carnavalesco de 2015 e resultado final da apuração do carnaval de 2015.

A análise dos enredos está delimitada aos anos de 2012, 2013, 2014 e 2015, pois obtive acesso somente a esses documentos. Em contrapartida, os sambas-enredos dos últimos dez anos serão analisados. 0 que complementa a análise dos enredos.

Ressalto o fato de a escola ter sido campeã do carnaval de Vitória/ES nos anos de 2006, 2007, 2008 e 2009. Por isso a análise dos sambas-enredos de 2006 a 2015, ou seja, dos últimos dez anos, é importante para a compreensão do contexto histórico da agremiação, uma vez que a manutenção da escola ao longo dos últimos carnavais está em análise. Segundo Pitt (1972), citado por Cavedon (2003, p. 156-157), “[...] a importância de se estudar o contexto histórico está na capacidade que o mesmo possui de permitir a compreensão da estabilidade e da mudança sociocultural [...]".

Além disso, a análise dos demais documentos (regulamento, setorização, script e resultado final da apuração) está delimitada às suas versões de 2015.

\subsubsection{FOTOGRAFIAS}

Durante minha observação também tive a oportunidade de tirar algumas fotografias. Por ser a produção de um desfile carnavalesco rica em imagens, procurei ter sempre em mãos uma máquina fotográfica ou um celular com câmera. Ao todo foram 632 fotos capturadas em diferentes espaços/contextos nos quais a produção do desfile carnavalesco aconteceu.

Nos estudos organizacionais, o uso de imagens/fotografias ainda não está difundido. Todavia, em pesquisas antropológicas e etnográficas o uso de imagens/fotografias como instrumento de pesquisa é comum e tradicional (BUCHANAN, 2001; FLICK, 2004). Por meio de imagens/fotografias é possível ilustrar com detalhes processos e práticas organizacionais muitas vezes complexos (BUCHANAN, 2001; FLICK, 2004). Dessa forma, esse instrumento de pesquisa pode complementar os métodos de observação e entrevista (BUCHANAN, 2001; FLICK, 2004), oferecendo um recurso adicional para a análise dos processos organizacionais (BUCHANAN, 2001).

Nesta pesquisa, as imagens/fotografias capturadas ao longo da observação da produção do desfile carnavalesco ajudarão a ilustrar minhas narrativas com mais detalhes, assim como algumas cenas do cotidiano da escola de samba e determinados elementos de suas práticas organizativas.

\subsection{ACESSANDO O CAMPO}

Meu primeiro contato com a escola de samba ocorreu no dia 28 de outubro de 2014. Nesse dia fui à sede da escola. Às 18h30min tinha uma reunião com a ex-diretora de harmonia (do carnaval de 2014), que mais tarde viria a ser minha informante. Obtive seu contado com meu orientador, pois dois de seus alunos já haviam realizado outras pesquisas com integrantes dessa escola de samba.

Confesso que estava com um frio na barriga; afinal, era a primeira vez que me predispunha a realizar uma pesquisa de campo qualitativa. Tinha em mente várias dúvidas e questionamentos: O que devo observar? O que devo perguntar? Como devo me comportar? Também estava receosa em relação à localização da sede da escola, pois sabia que esse era um espaço/contexto no qual as práticas organizativas se desdobravam e que, consequentemente, seria observado por mim durante a pesquisa. Apesar do meu receio, percebi que a sede ficava em uma avenida principal, de fácil acesso e movimentada. Nessa avenida havia uma pequena escadaria, cercada por casas. Era preciso subir essa escadaria para chegar até a sede. 
Já na sede da agremiação, fui recebida pela ex-diretora de harmonia. Ela estava com sua filha, pois morava bem ao lado da escola de samba. Nesse primeiro contato, também estavam presentes meu orientador e outra aluna de mestrado. Fomos recebidos com muita simpatia e atenção. Tivemos a oportunidade de conhecer todos os cômodos da sede e um pouco da história da agremiação. A ex-diretora também nos contou sobre os preparativos para o carnaval de 2015. Segundo ela, o enredo de 2015 homenageava o bicentenário da cidade de Itapemirim, uma cidade do sul do ES, sendo uma tentativa de patrocínio. Por fim, foi acordado que eu entraria em contato diretamente com o atual diretor de carnaval e que solicitaria a ele meu acesso ao campo. Fiquei muito esperançosa. Afinal, já nesse primeiro contato, que durou cerca de 2 horas, obtive informações relevantes para minha pesquisa.

Durante o mês de novembro, acompanhei o site e o facebook da escola, contatando o diretor de carnaval. No dia 25 desse mesmo mês, às 14h30min, fui conversar com ele. Marcamos nossa reunião em uma escola municipal, onde ele trabalhava. A reunião começou pontualmente, mas foi rápida, durou cerca de 30 minutos. Inicialmente, o diretor de carnaval se mostrou fechado. Pensei, então, em como poderia "quebrar o gelo". Percebi que havia um alfajor Havana sobre sua mesa de trabalho e comentei que adorava alfajor (o que é verdade!), para descontrair. Ele comentou que, apesar de não gostar de alfajor, ganhou um de presente de uma amiga. Somente após essa conversa inicial, me apresentei de modo mais formal, afirmando que gostaria de pesquisar o processo de produção do desfile carnavalesco.

O diretor de carnaval, então, começou a desabafar, relatando que "tudo estava atrasado" e que a escola ainda estava negociando o patrocínio com a prefeitura de Itapemirim. Além disso, o diretor relatou que "as verbas oficiais [do governo do estado e da prefeitura de Vitória] ainda não saíram. A previsão é que esses recursos sejam disponibilizadas só em janeiro de 2015, nas vésperas do Carnaval... Mas dinheiro não compra tempo! Não adianta liberar R\$ 1 milhão nas vésperas do carnaval, faltando 15 dias para o desfile". O diretor estava visivelmente preocupado com a situação financeira da escola.

Após conversarmos um pouco sobre a situação atual da escola de samba, expliquei que, para realizar minha pesquisa, precisaria ter acesso aos ensaios, aos barracões e às reuniões da escola, de dezembro até o Carnaval. Ele liberou meu acesso, sem sequer parar para pensar, frisando que poderia observar tudo, mas que, devido à correria, muitas vezes ele e os demais membros da escola não poderiam parar para nos atender. Ele também disse, em tom de brincadeira: "se precisar vou te colocar pra trabalhar, na correria você não vai ficar só olhando".

Como o barracão pesado da escola ainda não estava "aberto"; ou seja, em funcionamento, o diretor de carnaval recomendou que eu começasse minha pesquisa observando o ateliê onde os protótipos ${ }^{19}$ das fantasias das alas estavam sendo feitos pelo carnavalesco. Logo após essa reunião, contatei o carnavalesco. No dia seguinte (26 de novembro de 2015) fui conhecer o "ateliê de protótipos" e comecei, de fato, minha observação.

\subsubsection{O CONTINUUM ENTRE A OBSERVAÇÃO E A PARTICIPAÇÃO}

No decorrer da pesquisa de campo, a observação emergiu como minha principal forma de acesso às práticas empregadas na produção do desfile carnavalesco, algo inicialmente não planejado. Além disso, a "brincadeira" do diretor de carnaval se concretizou. Participei de algumas atividades que alteraram minha identidade no campo (de pesquisador para integrante da escola) e minha observação (de não participante para participante).

Segundo Scott (1972), é inevitável a existência de algum grau de participação durante a observação, afinal não há uma divisão estanque entre observação participante e não participante, sendo a dicotomia atribuída aos diferentes mecanismos de observação, na verdade, um continuum. Ou seja, independente da escolha do pesquisador, sempre haveria algum tipo de participação durante a observação.

Isso pôde ser constatado nos momentos em que realizei algumas atividades, como se fosse uma integrante da escola. Durante os ensaios, por exemplo, carreguei instrumentos da bateria, acendi as luzes e os

19 O carnavalesco da escola de samba é responsável por desenhar e confeccionar os protótipos das fantasias das alas. Essas fantasias costumam ser apresentadas para toda a comunidade da escola, em um dos ensaios gerais. Após a confecção dos protótipos, as fantasias são reproduzidas nos demais ateliês que trabalham com a agremiação. Os protótipos também costumam ser expostos na quadra da agremiação, para que os foliões possam escolher e comprar suas fantasias. 
ventiladores da quadra, carreguei fantasias, busquei materiais que seriam usados nas fantasias e consegui água para os integrantes de uma ala coreografada. No barracão pesado, ornamentei alegorias e lamentei a morte do presidente da agremiação (que, infelizmente, faleceu a dois dias do desfile) junto com os demais integrantes da escola. Na concentração e durante o desfile, ajudei o carnavalesco a entregar fantasias; consegui água para os integrantes da comissão de frente; atuei como apoio de destaque ${ }^{20}$, carregando costeiros $^{21}$ (ou esplendores); tirei dúvidas de foliões e orientei os puxadores ${ }^{22}$ a empurrarem um dos carros alegóricos, atuando como harmonia; além de desejar e receber condolências pela morte do presidente da escola.

Assim, vivenciei em meu trabalho de campo um processo de transformação da observação para a participação, ou seja, uma transição gradual no continuum dos mecanismos de observação, o que ilustra bem o fato de as fronteiras entre a observação participante e a não participante serem fluidas e nem sempre estarem sob o controle do pesquisador (SCOTT, 1972; TURETA; ALCADIPANI, 2011). O mais interessante é que essa transição, além de ter ocorrido de forma natural, parecia ser desejável e apreciada por parte dos pesquisados, dos integrantes da agremiação.

Pude perceber isso quando acompanhei, pela primeira vez, um ensaio geral, na quadra da escola. Assim que cheguei, por volta das 15 horas, percebi uma movimentação no $2^{\circ}$ pavimento da quadra. 0 mestre de bateria estava lá. Subi as escadas e fui falar com ele. Ele estava verificando quais instrumentos poderiam ser usados, separando os que estavam quebrados. Começamos a conversar. Perguntei quais instrumentos ele sabia tocar. Ele riu e respondeu: "todos". Eu, então, respondi: "claro, você é o mestre de bateria". Pedi desculpas e também dei risada. Ele, então, começou a descer com os instrumentos, arrumando-os em frente ao palco. Sem que ele pedisse, os integrantes da agremiação que estavam na quadra começaram a ajudar.

Eu não sabia o que fazer... Apenas observar ou ajudar? Resolvi ajudar! Usando as palavras de Schatzki, interpretei que "ajudar, sendo ou não solicitado" era uma "regra implícita", um "entendimento"; elementos que organizavam as práticas organizativas da escola de samba. Após carregar os instrumentos por alguns minutos, subindo e descendo as escadas do $2^{\circ}$ pavimento, fui presenteada pelo mestre de bateria com uma squeeze, nas cores da escola, com o nome da agremiação e parte do samba exaltação gravados. Além de me presentear, ele também agradeceu minha ajuda. Agradeci o presente e lhe dei um forte abraço.

O barracão pesado também foi um dos espaços no qual essa transição (da observação para a participação) aconteceu de maneira mais evidente. Vivenciei isso há menos de uma semana do desfile carnavalesco, quando fui ao barracão por volta das 9 horas da manhã. Nessa ocasião, percebi que havia um rapaz trabalhando sozinho, adereçando um tripé. Aproximei-me e me dei conta de que esse era o tripé que seria usado na coreografia da comissão de frente, representando uma oca. O tripé era uma estrutura de ferro, com cerca de 2 metros de altura, revestido com algodão cru. Para ornamentá-lo, era preciso colar esteiras e tiras de palha nessa estrutura. O rapaz que ornamentava o tripé era um dos integrantes da comissão. Nós já nos conhecíamos, uma vez que eu já havia acompanhado alguns ensaios da comissão. Aproximei-me e ofereci ajuda. Ele aceitou "na hora". Trabalhando por cerca de uma hora. Organizamos nosso trabalho da seguinte forma: Eu passava cola nas esteiras e ele as colava na oca. Como não havia mesa, tive que colocar as esteiras no chão e me abaixar, para então passar cola por toda a superfície de palha. Em seguida, eu me levantava e entregava as esteiras para ele. Ele, então, colava as esteiras na oca. O trabalho era simples, mas a falta de estrutura e o calor do barracão o tornavam exaustivo. Apesar de sentir minhas costas doendo e de estar com as mãos e a roupa sujas com cola de sapateiro, foi muito gratificante ver a alegoria ganhando forma.

No dia do desfile carnavalesco, a interação com os integrantes e os foliões da escola - desde a concentração no barracão pesado, até o desfile propriamente dito -e o fato de eu estar usando uma camisa de "apoio de destaque" também contribuíram para a transição da observação para a participação. Nesse dia, enquanto eu transitava pela área de concentração, fui abordada por duas pessoas. Elas se aproximaram de mim, bateram com a mão no meu ombro e me disseram: "Meus pêsames!". Referindo-se ao falecimento do presidente da escola. Eu agradeci, respondendo: "Obrigada!". Percebi, então, que a camisa de "apoio de destaque" que eu estava usando fazia com que as pessoas (integrantes ou não da escola) me identificassem como membro da escola de samba.

\footnotetext{
20 Integrantes da escola que auxiliam os destaques a vestirem suas fantasias, a carregarem e vestirem seus costeiros. 0 apoio de destaque também costuma fixar os costeiros nos carros alegóricos.

21 Elemento da fantasia que será "encaixado" no ombro do folião, dando "volume", complementando a fantasia.

22 Pessoas responsáveis por empurrar os carros alegóricos durante o desfile carnavalesco. Geralmente recebem cerca de $\mathrm{R} \$ 50,00$ para realizar essa tarefa.
} 
Mais tarde, ainda no dia do desfile, percebi que um dos integrantes da harmonia estava com um rolo de fitilho preto e uma caixa de alfinetes nas mãos. Alguns diretores e integrantes da diretoria de harmonia estavam fazendo pequenos laços com esse fitilho, colocando-o no peito, ou manga da camisa, em homenagem ao presidente que havia falecido. Um dos harmonias ${ }^{23}$ apontou o rolo de fitilho e a tesoura para mim. Eu peguei a tesoura, cortei um pequeno pedaço de fitilho e pedi alfinete. Em seguida, dobrei esse fitilho e fiz um laço, prendendo-o na minha camisa, na altura do peito. Conforme destaca Bresler (2009, p. 115), "Os artefatos, roupas entre eles, possuem diferentes significados dependendo de seu contexto ou domínio [...] uma roupa de trabalho, em outro domínio, se torna símbolo que pode integrar ou diferenciar pessoas".

Também destaco que, durante minha inserção no campo, tive a oportunidade de incorporar (enquanto pesquisadora-integrante) minha própria microversão dos elementos que organizaram o fazer estratégia da escola de samba; apreendendo os ditos e os feitos característicos do contexto estudado. Por exemplo, na concentração para o desfile, os integrantes da escola comentavam suas impressões a respeito dos carros alegóricos da escola e das outras agremiações. Muitas vezes, minha opinião - ou julgamento estético, conforme destaca Strati (1999) - sobre as alegorias era uma percepção compartilhada com esses integrantes. 0 mesmo ocorreu em relação ao desfile das escolas do Rio de Janeiro e de São Paulo, eu compartilhava a percepção dos integrantes, discordando de amigos e familiares. Alguns familiares, inclusive, passaram a comentar: "Você agora é sambista! Tá entendendo de carnaval, até acertou quem ia cair". Diante disso, eu mesma me questionava: "Como é possível? Eu nunca havia me interessado por carnaval, e agora sou capaz de julgar se uma escola foi bem ou mal, se as alegorias/fantasias foram bem feitas".

Assim, em várias oportunidades, vivenciei uma transição gradual no continuum da observação para a participação, transição essa que transformou minha identidade de pesquisadora, aproximando-a a de uma integrante da agremiação. Além disso, também procurei relativizar minhas percepções, com o intuito de compreender a realidade observada a partir de sua própria lógica de funcionamento, questionando meu entendimento sobre o cotidiano do campo (DALLA CHIESA; FANTINEL, 2014).

Diante disso, ressalto que as tensões entre o familiar e o estranho (DALLA CHIESA; FANTINEL, 2014) também se fizeram presentes durante minha pesquisa, o que pôde ser observado no último ensaio para o carnaval de 2015. Após 4 horas de observação, decidi deixar a quadra e ir embora. Porém, me vi parada, imobilizada, observando a bateria tocar. Minha vontade era apenas ouvir o samba, sem fazer anotações. Prestei atenção em cada detalhe: Nos passistas sambando, na batida da bateria, nos foliões cantando, na coruja que ornamenta o palco. Após alguns minutos, lembrei que meu marido estava me esperando, lá fora. Precisava ir embora! Mas não conseguia sair de frente do palco. Lembrei que, antes, no início da pesquisa, a quadra era um local quente e barulhento... ir embora, muitas vezes, era um alívio. Percebi, então, que minha identidade como pesquisadora se misturava à minha identidade como integrante da escola. Finalmente consegui sair da quadra. Desci a ladeira, em direção à avenida principal, onde meu marido me esperava, estacionado. Entrei no carro e uma lágrima escorreu... Senti uma mescla de alegria, alívio e saudade antecipada.

Todavia, apesar dessa "aculturação" (YANOW, 2012), concordo com Bresler (2009, p. 119), destacando que "[...] Algumas distâncias continuaram a persistir [...], não sei se um pesquisador é capaz de ultrapassá-las. Além da história e da origem social serem distintas, nosso propósito de estar ali, trabalhando, é totalmente diferente [...]". De todo modo, apesar dessa limitação, ressalto que a transição no continuum da observação para a participação me possibilitou não apenas presenciar in loco o desdobramento das práticas organizativas da escola de samba, mas também vivenciar experiências, entender o ponto de vista, a lógica que organiza a vida do "nativo", do "outro"; algo que somente a observação participante permitiria (MALINOWSKI, 1978). O que contribuiu para que eu compreendesse, de forma bem mais apurada, muito do que acompanhei durante a preparação do desfile carnavalesco (TURETA; ALCADIPANI, 2011). Como destaca Bresler (2009, p. 119), “[...] talvez o fato de ter acesso a informações, ritos e processos seja o mais importante neste tipo de pesquisa, dada a impossibilidade de aceitação total e plena".

\subsection{ANALISANDO OS DADOS}

Em relação à análise e interpretação dos dados, este trabalho empregará o procedimento de análise de conteúdo temático a posteriori (FRANCO, 2012; KRIPPENDORFF, 2004), seguindo o procedimento em espiral de análise de dados proposto por Creswell (2012).

23 Os integrantes da diretoria de harmonia são conhecidos como "harmonias". 
O ponto de partida da análise de conteúdo é a mensagem, seja ela oral, escrita, gestual, figurativa ou documental; estando essa mensagem, necessariamente, vinculada a um contexto específico. Assim, a análise de conteúdo se afasta de uma concepção formalista da linguagem, considerando-a uma construção social, uma expressão da existência humana, uma vez que os indivíduos, ou grupos, atribuem sentido à mensagem (FRANCO, 2012).

Dito isso, o primeiro desafio do pesquisador que utiliza a análise de conteúdo é organizar a análise (pré-análise), escolhendo o conjunto de documentos (corpus) que será analisado. Só então, o pesquisador estará apto para explorar o conteúdo do corpus; devendo refletir sobre seu sentido geral/global. Em seguida, começa a análise detalhada, com a definição das categorias de análise que serão usadas para diferenciar e reagrupar todo o conteúdo (FRANCO, 2012). Para tal, durante o processo de análise, o pesquisador precisa ir e vir, de seu referencial teórico ao material em análise (FRANCO, 2012; KRIPPENDORFF, 2004). Conforme mencionado, neste trabalho a categorização será a posteriori, emergindo do conteúdo.

Vale ressaltar, ainda, que, por meio da análise de conteúdo (e com base no conteúdo manifesto e "capturável"), o pesquisador busca fazer inferências; o que implica comparações textuais, o entendimento das semelhanças e das diferenças em relação a um dado referencial teórico (FRANCO, 2012). Todavia, isso não significa que o pesquisador deve se abster da análise do conteúdo latente, das entrelinhas; uma vez que a informação puramente descritiva de um conteúdo tem pouca relevância teórica. É justamente a inferência que permite que o pesquisador qualitativo passe da mera descrição à interpretação, dando significado à mensagem (FRANCO, 2012; KRIPPENDORFF, 2004).

Quanto ao procedimento em espiral de análise de dados, Creswell (2012) destaca que os processos de coleta, análise e narrativa dos dados qualitativos são inter-relacionados e, muitas vezes, simultâneos. Dessa forma, a imagem de um espiral (e não um "passo a passo" linear) seria a mais apropriada para representar a análise de dados; uma vez que o pesquisador qualitativo lida com as várias facetas do conteúdo do corpus (texto e imagem, por exemplo), engajando-se em uma análise circular (CRESWELL, 2012), precisando ir e vir de seu referencial ao material em análise (FRANCO, 2012; KRIPPENDORFF, 2004).

A seguir, apresento, por meio de categorias temáticas, as práticas estratégicas - o conjunto de atividades organizadas e arranjos materiais (SCHATZKI, 2005) - que compõem o fazer estratégia da escola de samba. A análise dos dados revelou cinco categorias e dez subcategorias.

Quadro 2 - Categorias emergentes da análise dos dados

\begin{tabular}{|l|l|}
\multicolumn{1}{|c|}{ Categorias Temáticas } & \multicolumn{1}{c|}{ Subcategorias Temáticas } \\
\hline $\begin{array}{l}\text { Carnavalizando Um “Enredo Caça } \\
\text { Níquel" }\end{array}$ & - \\
\hline \multirow{2}{*}{ Jogando As Regras Do Jogo } & Contratando Profissionais Do Carnaval \\
\cline { 2 - 2 } & (Re)Lendo O Enredo \\
\hline \multirow{3}{*}{ Produzindo Carros Alegóricos } & (Re)Aproveitando A Estrutura Dos Carros \\
\cline { 2 - 2 } & (Re)Utilizando Esculturas \\
\cline { 2 - 2 } & "Tamanho Não É Documento!" \\
\hline \multirow{2}{*}{ (Re)Produzindo Fantasias } & Descentralizando A Reprodução Das Fantasias Das Alas \\
\cline { 2 - 2 } & Repaginando As Fantasias Dos Destaques \\
\hline \multirow{2}{*}{ (Re)Vivendo O Carnaval } & A Socialização Dos Integrantes Da Escola \\
\cline { 2 - 2 } & (Véspera De) Carnaval \\
\hline
\end{tabular}

Fonte: Elaborado pela autora

Com o intuito de realizar a análise de conteúdo, optei por "recortar" meus dados. Dessa forma, reuni todas as notas de campo de acordo com o espaço organizacional no qual as observações aconteceram. Assim, separei as notas em três grandes grupos: barracão pesado; ateliês; e quadra. Logo em seguida, separei os áudios e as transcrições das entrevistas, agrupando-as em um mesmo diretório. Fiz o mesmo com os 
documentos e as fotografias, agrupando-os em pastas específicas no meu computador.

Após essa pré-análise, iniciei a leitura dos dados pelos documentos, refletindo sobre seu conteúdo. Esse foi um dos momentos mais prazerosos da análise dos dados, já que pude ler as letras dos sambas enquanto escutava sua gravação. Logo em seguida, realizei a leitura das notas de campo do barracão, da quadra e dos ateliês. Por fim, li as notas que foram tomadas em outros espaços/contextos organizacionais: durante os ensaios de rua, no desfile carnavalesco e na apuração dos resultados. O próximo passo foi a leitura das transcrições das entrevistas (preferi ler e escutar as entrevistas ao mesmo tempo). Durante essa reflexão inicial revive minha interação com o campo (ri sozinha, sambei, lembrei de momentos muito agradáveis e de algumas "saias justas"); codificando os dados por assunto (por exemplo: enredo, fantasia, alegoria, crise financeira, regras, entendimentos, teleoafetividades, história de vida, quesitos, carnavalesco, profissionais, colorido, acabamento, escolas coirmãs, organização, desorganização, luxo, aproveitamento de materiais, pesquisadora-foliã-integrante, etc.).

Em seguida, comecei a análise detalhada, agrupando os códigos em categorias e subcategorias; destaco que esse processo foi marcado por idas e vindas. Por exemplo: inicialmente, obtive quatro categorias e duas subcategorias. Nessa etapa, "Contratando especialistas" (que abarcava os códigos "quesitos", "carnavalesco", "profissionais", etc.) e "Jogando as regras do jogo" (que relacionava os códigos "enredo", "crise financeira", "regras", "entendimentos", etc.) eram duas categorias. Mais tarde, optei por considerar "Jogando as regras do jogo" como uma categoria, transformando "Contratando especialistas" em uma das suas subcategorias.

Por fim, ressalto que, apesar de ter organizado os dados por espaço organizacional, as categorias que emergiram da análise relatam práticas/atividades estratégicas que aconteceram em vários desses espaços, uma vez que o contexto no qual uma prática se desdobra está "para além" de um espaço físico (SCHATZKI, 2005). 


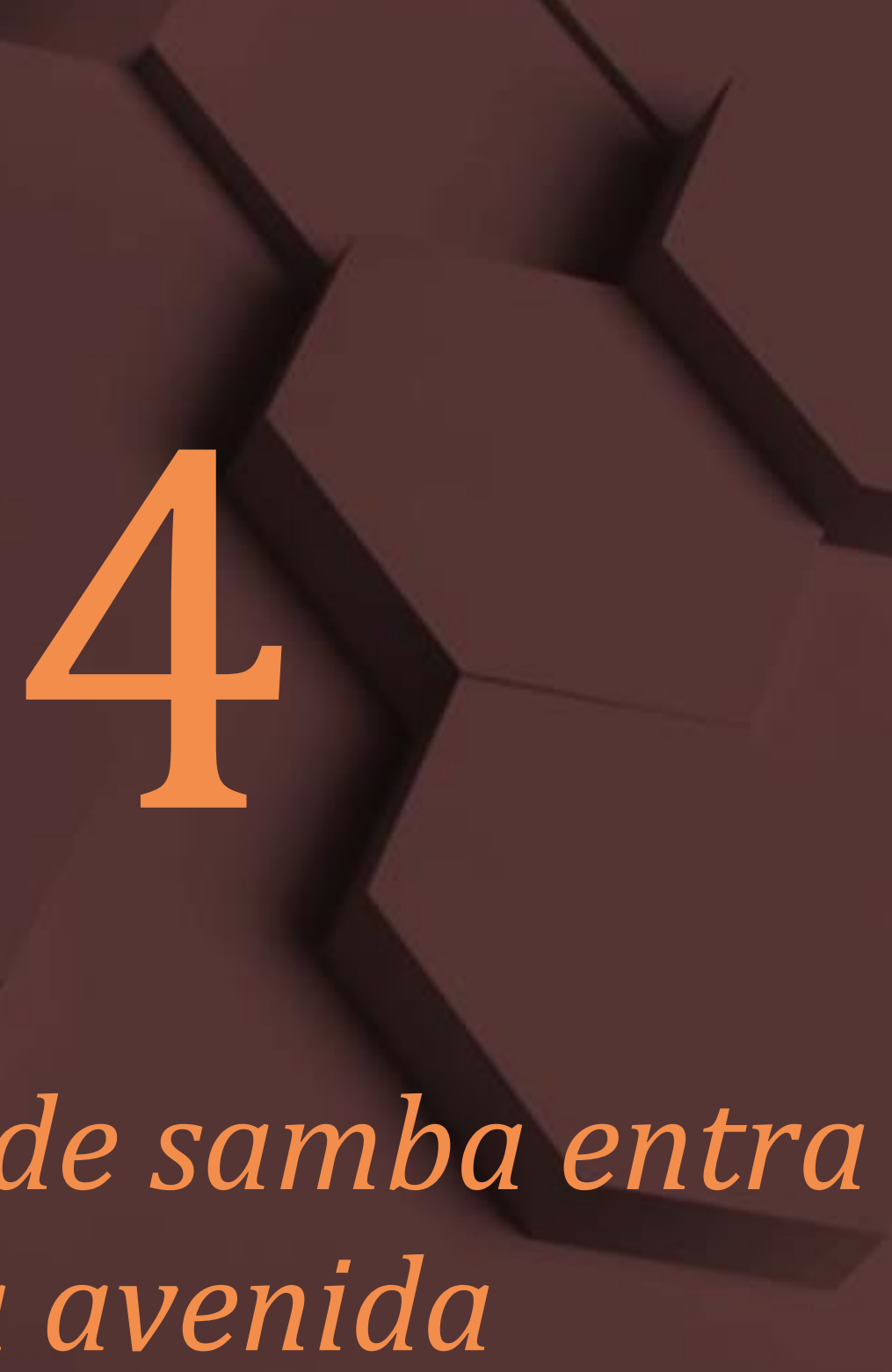




\section{A ESCOLA DE SAMBA ENTRA NA AVENIDA}

\subsection{ESTRUTURA ORGANIZACIONAL}

A estrutura organizacional da escola de samba conta com a presidência e diversos departamentos; a saber: diretorias de carnaval, harmonia ${ }^{24}$, bateria, patrimônio, comunicação e marketing, desenvolvimento social e financeira; assim como coordenação da velha-guarda, das alas das baianas, crianças, passistas, compositores e comunidade.

Os cargos de presidente e vice são ocupados por pessoas eleitas pelo conselho da agremiação, que, por sua vez, é formado pelos fundadores da escola. Os cargos de diretoria são ocupados por pessoas indicadas pela presidência. Cada um dos diretores, por fim, tem a liberdade de indicar para os cargos de diretores adjuntos e coordenadores pessoas de sua confiança, que irão trabalhar no seu setor.

Alguns desses departamentos estão diretamente envolvidos na produção do desfile carnavalesco, enquanto que outros são responsáveis por atividades de caráter social ou pela promoção/participação em eventos. Durante a pesquisa de campo tive mais contato com o carnavalesco e com algumas diretorias e coordenações que estavam diretamente envolvidas na produção do desfile, a saber: diretoria de carnaval, harmonia e bateria; assim como coordenação das alas das baianas, das crianças e da comunidade.

Destaco, ainda, que durante o ciclo carnavalesco de 2014/2015 não havia, pelo menos formalmente, uma comissão de carnaval. Após o desfile de 2014, essa comissão foi "extinta" pelo presidente da agremiação, cabendo ao diretor de carnaval, ao carnavalesco e ao diretor de comunicação a responsabilidade de "colocar a escola na avenida". Inclusive, considerava-se, de modo "honorário", o diretor de comunicação como um diretor adjunto de carnaval.. Diante disso, o carnavalesco e esses diretores eram considerados pelos integrantes da escola de samba como os representantes da comissão de carnaval.

\subsubsection{O CONTEXTO PRODUZIDO PELA ESCOLA}

Segundo Schatzki (2006), o contexto no qual a coexistência humana e os fenômenos sociais se desdobram é composto por um nexo de práticas organizadas e arranjos materiais; sendo os fenômenos sociais parte inerente desse contexto. Assim, é possível afirmar que a organização escola de samba, como qualquer outro fenômeno social, também se desdobra e é parte inerente de um contexto. O que pode ser evidenciado pelo fato de uma das características básicas de uma escola ser a vinculação ao local onde se encontra sediada. Além disso, a agremiação teria a função de representar sua "comunidade", ampliando seu espaço social (CAVALCANTI, 1994).

Além da sede e da quadra, a escola também se desdobrou, como um fenômeno social, no barracão pesado e nos ateliês.

\subsubsection{A SEDE}

O acesso à sede da escola de samba se dá pela avenida principal do bairro, um local movimentado e de fácil acesso. Nessa avenida há uma pequena escadaria, cercada por casas. É preciso subir essa escadaria para chegar até a casa, que fica no "pé" do Morro do Cruzamento.

Na casa há sala, quartos, cozinha, varanda, banheiro e uma churrasqueira no quintal. Cada um dos cômodos leva o nome de algum ex-integrante da agremiação, todos já falecidos. A cozinha, por exemplo, homenageia um ex-integrante que gostava de cozinhar e fazia "paneladas" após os ensaios, para que as pessoas que estavam ensaiando pudessem almoçar. Na varanda, por sua vez, estão os troféus e prêmios que a escola já recebeu nos últimos carnavais, a primeira coisa que alguém vê quando chega à sede da escola. $\mathrm{Na}$ sala, há fotos dos ex-presidentes da agremiação. Segundo a diretora adjunta de carnaval, que foi minha informante durante a observação, muitas dessas fotos foram levadas pelos fotografados (ex-presidentes), como lembrança.

\footnotetext{
$24 \mathrm{Na}$ escola de samba, o setor de harmonia é o principal responsável pela evolução da escola de samba na avenida, pela execução/performance do desfile. A coordenação das alas das baianas e das crianças é subordinada ao setor de harmonia, que também é o principal responsável pelos ensaios gerais.
} 
As reuniões da presidência com as diretorias, assim como algumas reuniões de diretorias mais específicas costumavam acontecer na sede da escola. Durante minha observação, tive a oportunidade de participar de uma dessas reuniões. Na ocasião, os coreógrafos da comissão de frente se reuniram com a diretoria de carnaval e o carnavalesco para tratar da evolução do primeiro setor, das alegorias e das fantasias que seriam usadas durante a coreografia da comissão.

\subsubsection{A QUADRA}

A quadra utilizada pela agremiação é alugada, localizando-se a cerca de 400 metros da sede da escola. Em referência ao clube, a quadra também é conhecida por "Anchietinha".

Para chegar à quadra é preciso subir uma pequena ladeira, uma rua perpendicular à avenida principal do bairro. O local é grande e de fácil acesso, mas muito quente. Nos últimos anos, a escola teve problemas com a vizinhança, que, por conta do barulho dos ensaios, costumava acionar o "disque silêncio" da prefeitura de Vitória. Por esse motivo, os ensaios gerais estão autorizados a acontecer somente aos domingos à noite. Com o intuito de conter, pelo menos um pouco, o barulho e melhorar a relação com a vizinhança, a quadra foi completamente fechada, não havendo ventilação natural. Além disso, há poucos ventiladores, o que torna esse espaço muito quente.

No centro da quadra há um palco, ornamentado com tecidos dourados e uma coruja (um dos símbolos da escola), onde os intérpretes dos sambas-enredos se apresentavam durante os ensaios gerais de domingo. Dos lados direito e esquerdo do palco havia uma grande estrutura de ferro, com a letra do samba-enredo de 2015.

Durante os ensaios gerais de domingo, a área em frente ao palco era reservada para a bateria, sendo demarcada por uma estrutura de ferro ornamentada com tecidos verde e vermelho, as cores da escola. Nesses ensaios, do lado direito do palco, alambrados costumam demarcar uma área VIP, onde algumas mesas e cadeiras eram posicionadas. Nessa área também havia um banner com a imagem da rainha da bateria do carnaval 2015. Os banheiros ficam ao lado dessa área VIP.

Na quadra também há um segundo piso, que fica em cima da estrutura física dos banheiros, uma espécie de varanda, que também era usada como área VIP. No muro da varanda havia uma imagem de São Jorge em uma pequena capela, iluminada por uma luz vermelha. Nessa varanda também eram guardados os instrumentos da bateria. No mesmo muro também havia um outdoor com o nome, o pavilhão da agremiação e o enredo de 2015. Na quadra também havia um bar, onde cerveja, refrigerante e água eram vendidos durante os ensaios de domingo.

Fotografia 1 - Área VIP (Durante ensaio geral na quadra da escola)

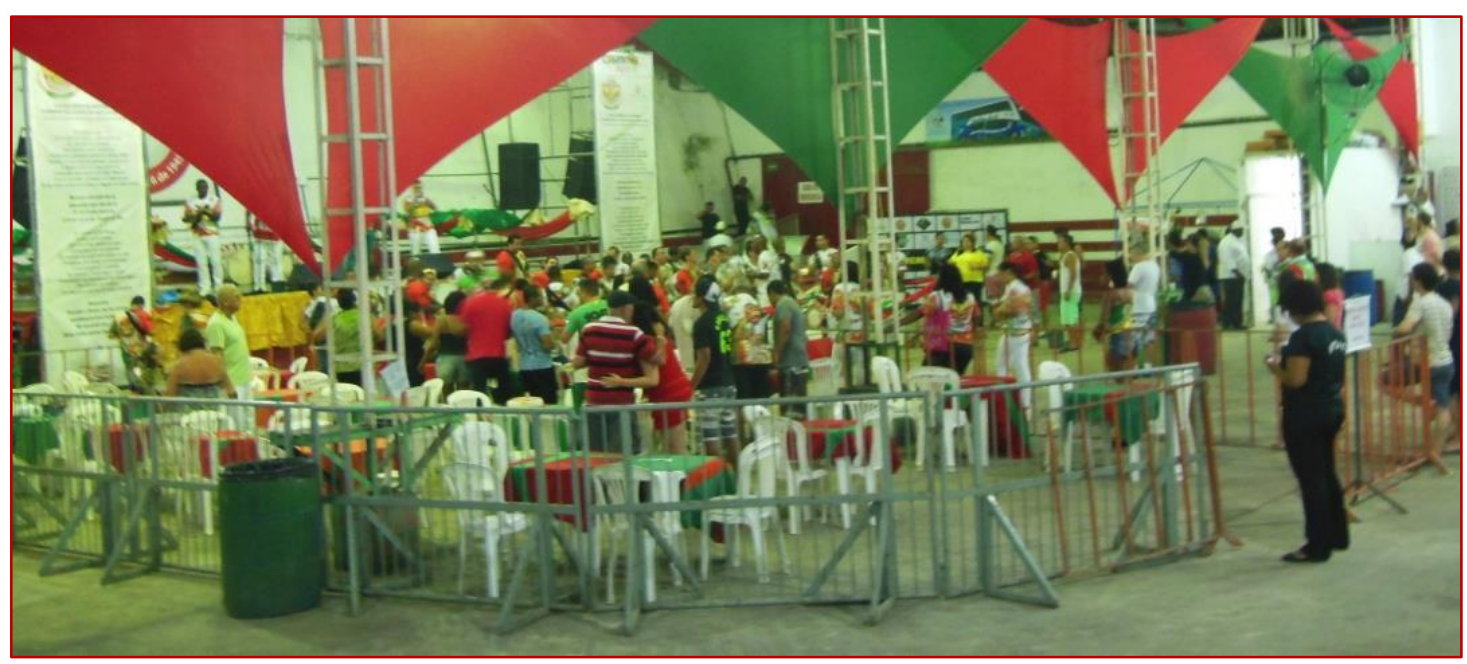

Fonte: Fotografia tirada pela autora 
Além dos ensaios gerais de domingo - oportunidade na qual intérpretes, bateria, casais de mestre sala (MS) e porta bandeira (PB), passistas e baianas ensaiavam - a quadra também era o espaço no qual as alas coreografadas e a bateria ensaiavam separadamente.

Fotografia 2 - Ensaio da ala das baianas na quadra da escola

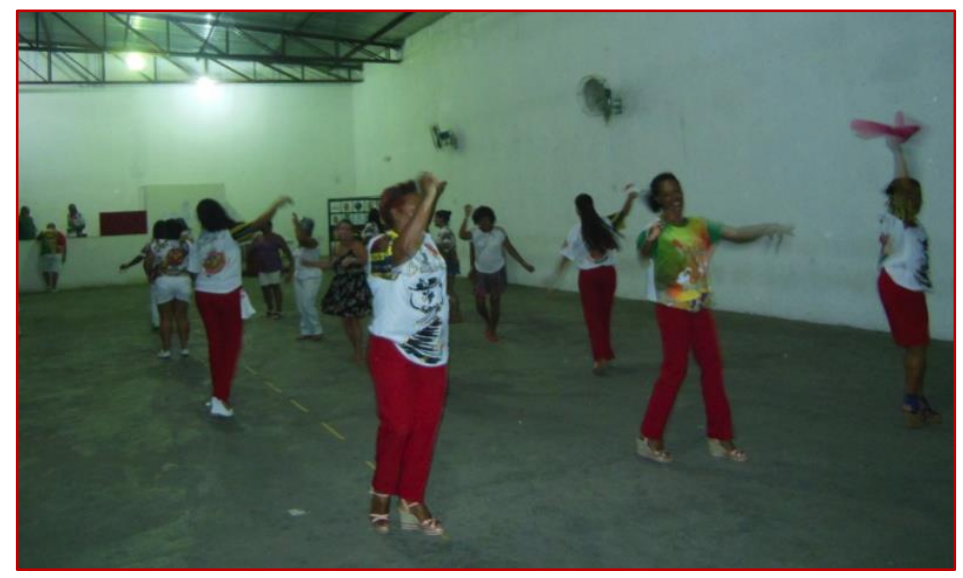

Fonte: Fotografia tirada pela autora

Durante minha observação, feijoadas, reuniões, exposição, venda e entrega de fantasias e até mesmo o velório do então presidente da agremiação, que, infelizmente, faleceu na véspera do desfile carnavalesco, também aconteceram nesse espaço.

Fotografia 3 - Exposição e venda de fantasias (Ensaio geral na quadra da escola)

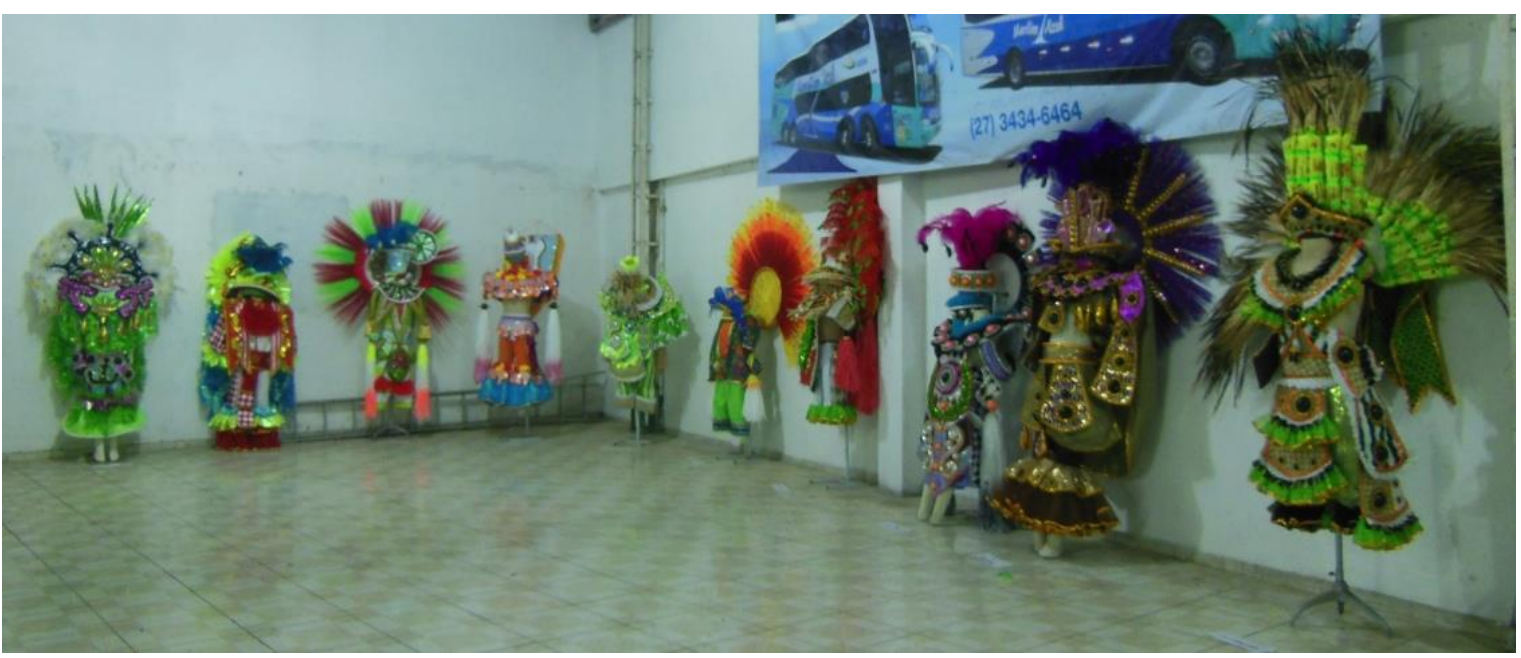

Fonte: Fotografia tirada pela autora

\subsubsection{O BARRACÃO PESADO}

O barracão pesado é o espaço no qual os carros alegóricos, os tripés ${ }^{25}$ e as esculturas que serão usados no desfile carnavalesco são produzidos. O barracão da escola de samba localiza-se bem próximo ao sambão do povo, onde ocorrem os desfiles carnavalescos de Vitória/ES. Trata-se de um terreno coberto, cedido há 3 anos por um dos integrantes da escola. Segundo a diretoria adjunta de carnaval, o proprietário do terreno costuma pedir em troca cerca de 10 fantasias, para que amigos e familiares possam desfilar na escola.

25 Pequeno carro alegórico no qual não há pessoas desfilando 
Fotografia 4 - Vista interna do barracão pesado

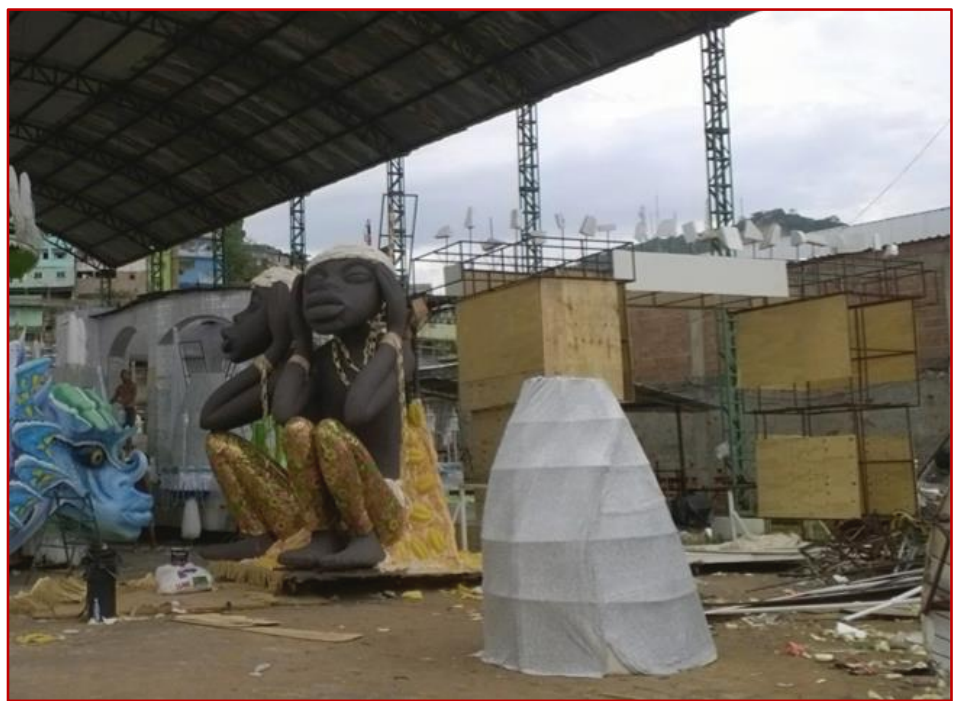

Fonte: Fotografia tirada pela autora

Metade do terreno é coberto por uma estrutura semelhante à usada em quadras esportivas. Há, ainda, duas entradas: Um portão grande, que dá acesso à rua do sambão do povo, e um portão pequeno, que dá acesso à rua de trás. O portão grande permite que os carros alegóricos entrem e saiam do barracão. Já o portão pequeno permite apenas a passagem de pedestres e de pequenos materiais usados na produção das alegorias. No interior do barracão também há dois cômodos pequenos e um banheiro.

Fotografia 5 - Vista externa do barracão pesado

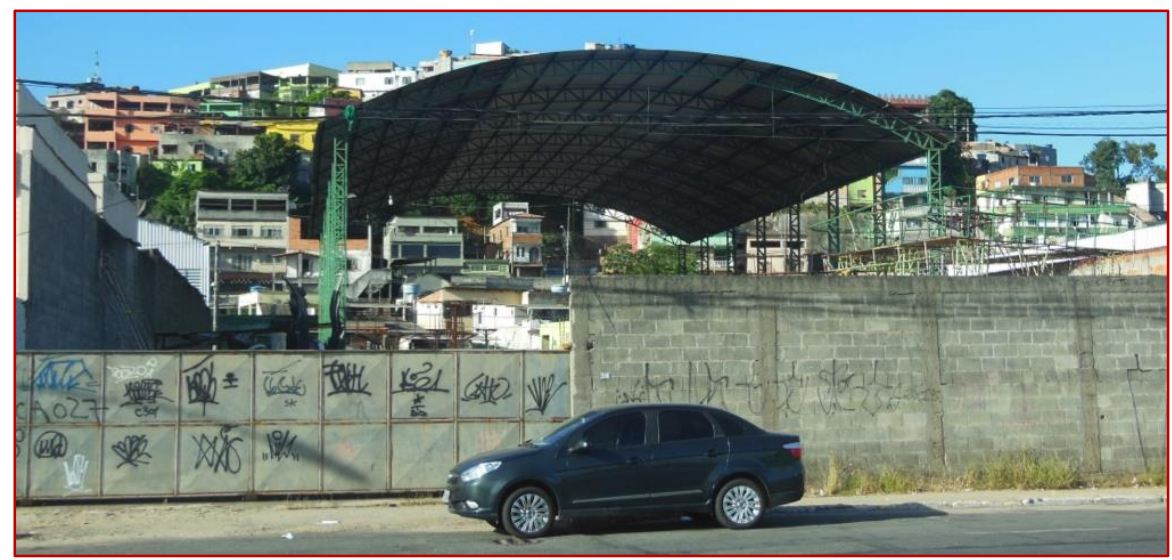

Fonte: Fotografia tirada pela autora

Devido à sua localização privilegiada (na mesma rua do sambão do povo), no dia do desfile carnavalesco, o barracão também serviu de ponto de encontro para os integrantes da agremiação. Além disso, os integrantes da comissão de frente, da bateria, da ala das baianas, das alas coreografadas e o primeiro casal de MS e PB se maquiaram e se vestiram no barracão. 


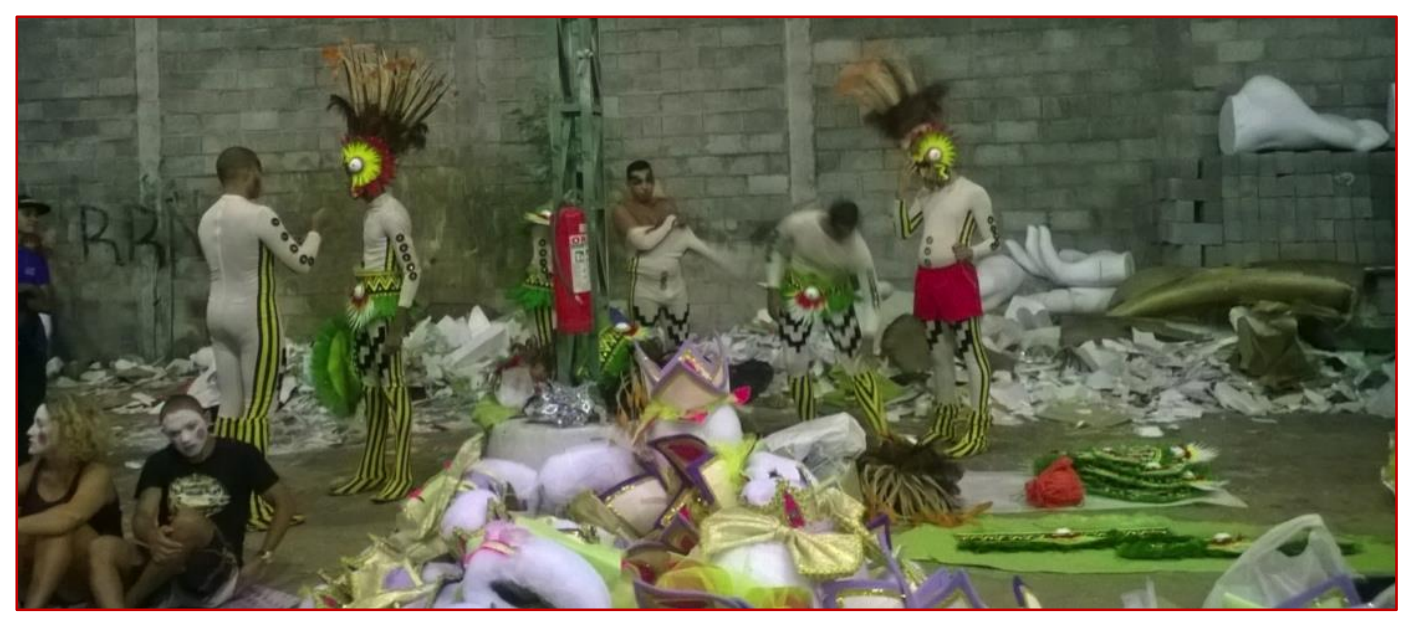

Fonte: Fotografia tirada pela autora

\subsubsection{OS ATELIÊS}

No ciclo carnavalesco de 2014/2015 não havia um grande barracão, comumente chamado de barracão leve, onde estilistas e costureiras trabalhassem juntos. A diretoria de carnaval e o carnavalesco optaram por produzir as fantasias em diversos ateliês, de diferentes estilistas.

No decorrer da pesquisa de campo tive a oportunidade de conhecer cinco desses ateliês. Quatro deles eram, na verdade, a própria casa dos etilistas. Durante os meses de dezembro e janeiro, assim como na primeira semana de fevereiro, os estilistas transformavam alguns cômodos de suas casas em um pequeno ateliê, estocando os materiais que seriam usados na confecção das fantasias (como tecidos, ferragens, plumas e pedrarias) e guardando as peças que ficavam prontas. Nas paredes da casa, os estilistas costumavam colar os croquis das fantasias que seriam produzidas. Mesas, cadeiras e sofás eram afastados, colocados no canto das paredes dos cômodos, para que a área de circulação dessas "casas-ateliês" ficasse maior. Dessa forma, salas, varandas e quartos transformavam-se em local de trabalho.

Fotografia 7 - Ateliê de confecção dos protótipos das fantasias

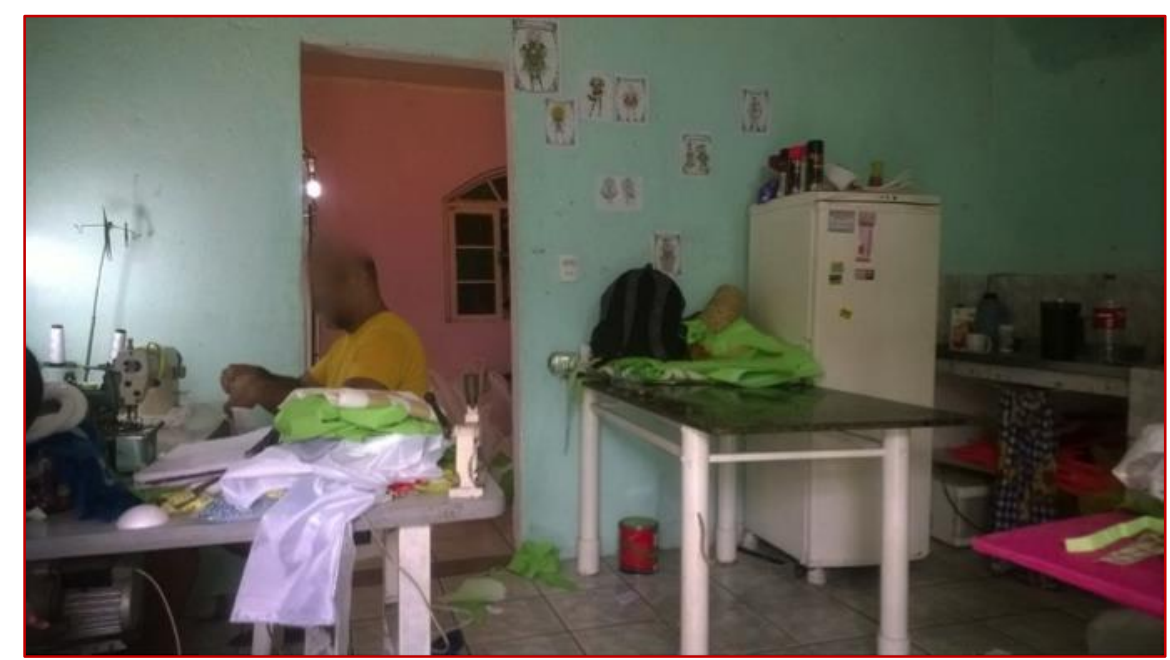

Fonte: Fotografia tirada pela autora 
Fotografia 8 - Ateliê de confecção de destaques e composição ${ }^{26}$ de carros

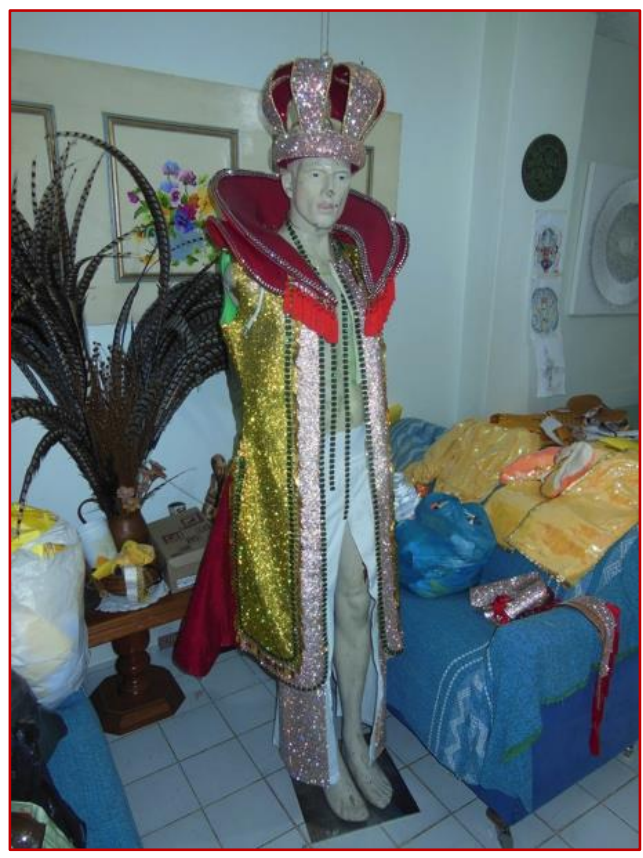

Fonte: Fotografia tirada pela autora

26 Uma alegoria também conta com composições, pessoas que desfilam em cima dos carros com fantasias mais simples, que compõem os adereços desses carros. 


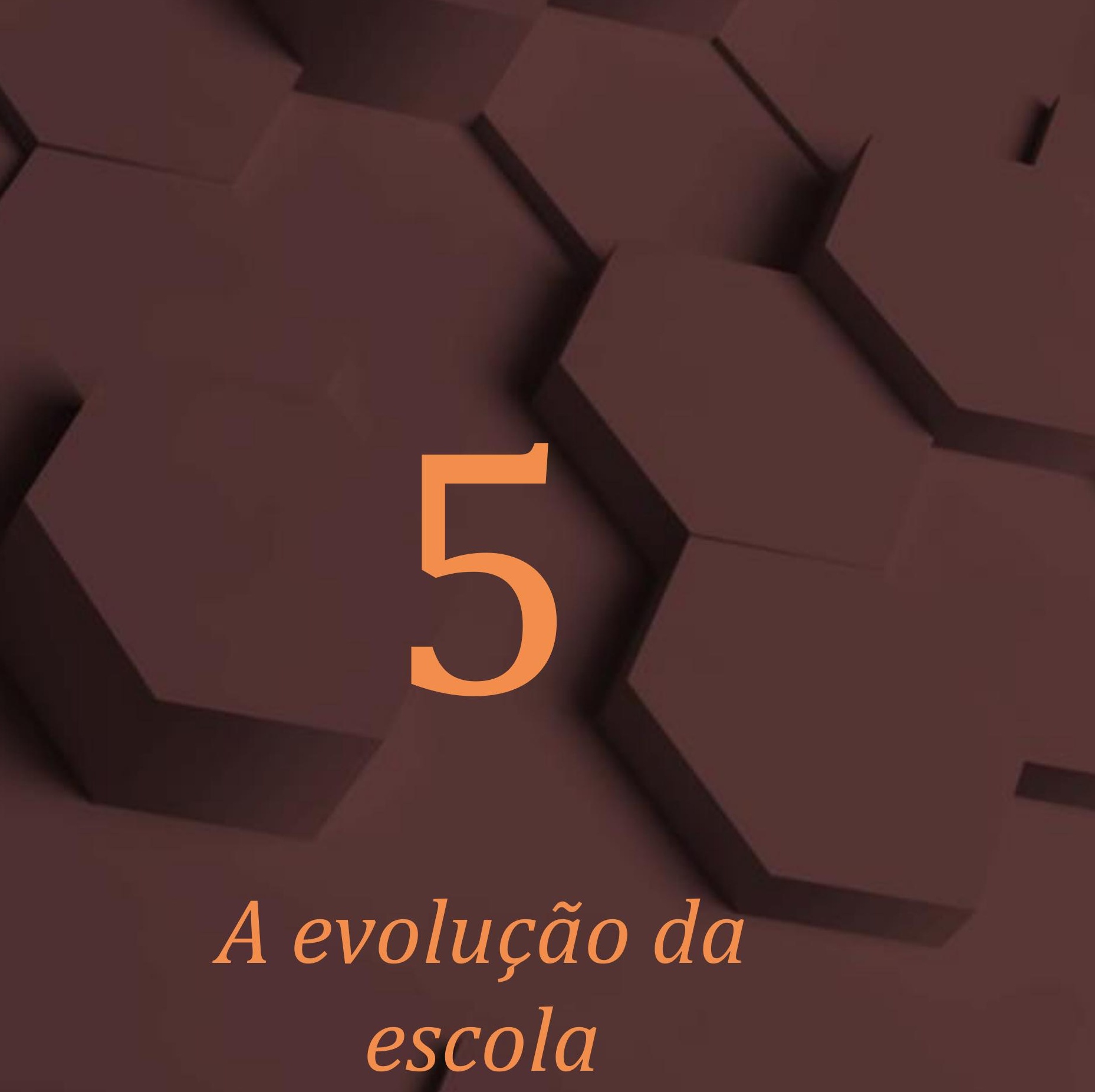




\section{EVOLUÇÃO DA ESCOLA}

Neste tópico retomo as cinco categorias temáticas e as dez subcategorias temáticas que emergiram da análise dos dados, apresentando o fazer estratégia da escola de samba.

\subsection{CARNAVALIZANDO UM “ENREDO CAÇA NÍQUEL"}

Em 2015, o enredo da escola tinha o seguinte título: "Itapemirim: sob o caminhos das águas, às suas ordens". De acordo com o script do desfile, o enredo de 2015 era uma homenagem a cidade de Itapemirim, um dos municípios mais antigos do Espírito Santo, que completava 200 anos. Segundo a diretoria de carnaval e o carnavalesco, o enredo foi sugerido por um dos enredistas e escolhido pela presidência da agremiação no início do ciclo carnavalesco de 2014/2015, em abril de 2014. A homenagem feita no enredo era uma tentativa de patrocínio. Por isso, o mesmo era chamado de "enredo caça níquel".

[...] esse ano, ele [o enredista] apresentou dois enredos: um [...] era sobre os movimentos sociais [...] a idéia era puxar todos os movimentos sociais da história [...] um enredo muito legal, fácil de fazer, só que não tinha patrocínio nenhum, a gente teria que bancar tudo. Ele também veio com essa proposta de Itapemirim, ele já conhecia o prefeito [...] e o município fazia 200 anos, é aniversario da cidade, então a gente sabia que a cidade estaria em festa. E como lá tem muito dinheiro de royalties, seria um canal pra se tentar conseguir algum patrocínio. [...] Como a gente estava numa situação financeira muito delicada, a gente falou: 'bom, vamos tentar Itapemirim'. Porque, tipo assim, o outro enredo a gente vai ter que gastar do nosso bolso, Itapemirim pode ser que dê certo, pode ser que não dê [...] então Itapemirim, pelo menos, é uma possibilidade (Entrevista diretor adjunto de carnaval e diretor de comunicação)

As escolas de samba da região metropolitana de Vitória/ES recebem uma ajuda de custo do governo do estado e da prefeitura de Vitória. Todavia, esse valor é pago na véspera ou até mesmo após o desfile. Com o intuito de amenizar essa situação, o governo disponibiliza cartas de créditos. Todavia, mesmo com essas cartas, as agremiações podem comprar apenas parte dos materiais necessários para a produção do desfile, uma vez que esse crédito é aceito somente em alguns estabelecimentos comerciais, todos localizados na cidade do Rio de Janeiro/RJ. Além disso, a ajuda governamental não é suficiente para cobrir todo o custo de produção de um desfile carnavalesco, já que "o carnaval é uma festa cara". Na véspera do carnaval, por exemplo, numa única pena de faisão (considerada a pluma mais luxuosa do carnaval) pode custar até $\mathrm{R} \$ 89$. Vale ressaltar que a fantasia de um destaque central de carro alegórico é composta por até duas mil penas de faisão, podendo custar cerca de R\$ 175 mil. Além disso, um carro alegórico não tem apenas um destaque central, contando também com até 3 semi-destaques e 15 composições de carro. Confesso que tais cifras chamaram muito minha atenção, especialmente no início da pesquisa.

Conforme destacam dois entrevistados, foi justamente esse cenário de dificuldades financeiras que levou a escola a optar por um enredo patrocinado.

[...] essa homenagem à Itapemirim [...] envolve dinheiro, e carnaval é luxo, é dinheiro [...]. Se você tem um enredo que foi muito bem escrito e o samba passa exatamente do início ao fim tudo isso. [...] não é um enredo que encanta, mas se ele for muito bem apresentado na avenida... querida! (Entrevista destaque e estilista 2)

[...] a gente também tem que entender que hoje [...] se você não tiver uma ajuda de fora, fica difícil! Porque o carnaval hoje é uma indústria milionária! Então, ou você aceita, ou você vai ficar pra trás... e com dívidas ainda! (Entrevista carnavalesco).

Diante disso, muitos integrantes da agremiação afirmavam que o objetivo da escola de samba para o carnaval de 2015 era "colocar a escola na avenida", mantendo-se no grupo especial, ou seja, "passar pela avenida pra não cair". 
[...] quando a gente começou o projeto, o objetivo era ser campeã. Agora [...] a gente é realista, nós pretendemos fazer um bom desfile [...]. Uma boa colocação pra gente seria 20 ou 30 lugar. [...] Porque 40 você está quase sendo rebaixado e a 5 a é rebaixada, né! Então agora a gente briga pra não cair e pra ficar numa boa posição (Entrevista diretor adjunto de carnaval e diretor de comunicação)

[...]cria uma certa agonia [...], porque você sabe que a escola não está preparada [...]. Mas ela tem que se manter, porque se ela não ficar entre as quatro melhores [...] ela cai pro grupo B [...]. E isso é um medo, porque hoje as escolas estão se profissionalizando. [...] Todas estão [...] forte, então qualquer uma pode descer. Dá um medo [...] É um campeonato! (Entrevista destaque e estilista 2)

O objetivo dela [da diretoria da escola] é colocar o carnaval na avenida, do jeito que for. Esse ano ela sabe que não ganha. É lógico que todo mundo quer ganhar, mas esse ano é colocar o carnaval lá [...]. (Entrevista diretora adjunta de carnaval)

Todavia, como ressalta um dos diretores da escola, o problema de um enredo patrocinado é que depois que a agremiação grava o samba-enredo não se pode voltar atrás, ou seja, mesmo que a escola não receba o dinheiro do patrocínio, não há como mudar o enredo. Dessa forma, produzir um desfile carnavalesco baseando-se em um enredo patrocinado é "um tiro no escuro". Foi justamente isso o que ocorreu com a agremiação entre os anos de 2006 e 2009 (quando a escola sagrou-se tetra campeã consecutiva do carnaval capixaba) e durante o ciclo carnavalesco de 2014/2015. Também pude perceber que para aumentar as chances de patrocínio, a escola procurou abordar temas capixabas em seu enredo. Assim, homenagear cidades (como Linhares e Itapemirim) e evocar elementos da cultura local (a torta capixaba, por exemplo) são exemplos de táticas utilizadas quando se escreve um "enredo caça níquel".

A primeira escola a falar sobre coisas capixabas foi a nossa, em 90. [...] E foi o primeiro título [...] eles comparavam a mistura das coisas da torta capixaba [...] com a mistura de raças do ES. [...] desde lá, a escola vem sempre fazendo enredos capixabas [...] esses quatro títulos [do carnaval de 2006 a 2009] foram coisas capixabas. [...] $\mathrm{O}$ de Linhares foi o único patrocinado [...] Difícil de sair, mas na última hora saiu. [...] é um tiro no escuro! Você vai lá, apresenta a proposta, normalmente fala que gosta, mas acaba pulando fora. (Entrevista diretor adjunto de carnaval e diretor de comunicação)

Diante disso, passei a me questionar o porquê de a produção de um desfile ser algo tão caro, mesmo quando se fala da realidade do carnaval capixaba (vale ressaltar que uma escola do grupo especial gasta cerca de $\mathbf{R} 500.000$ para produzir seu desfile, o que inclui carros alegóricos e fantasias). Pude perceber que um desfile era considerado "bom" quando a escola "trazia luxo para avenida", impactando visualmente o público e, principalmente, os jurados. Dessa forma, entre os diretores, o carnavalesco e, até mesmo, os demais integrantes e foliões da agremiação, havia a percepção de que para a escola se sair "bem" era preciso ter carros alegóricos, fantasias (das alas e dos destaques) e coreografias bem feitos. Era justamente essa percepção que fazia com que o carnaval fosse tido como uma festa cara, o que justificava, assim, a necessidade de um "enredo caça níquel".

\subsection{JOGANDO AS REGRAS DO JOGO}

Ao longo desta pesquisa, ao acompanhar o cotidiano da escola de samba, pude perceber que havia uma percepção (muitas vezes tácita, não verbalizada) compartilhada pelos integrantes da agremiação de que seria difícil "brigar" pelo campeonato do carnaval 2015. Os integrantes também relatavam que, nos últimos anos, a disputa pelo carnaval estava cada vez mais acirrada, uma vez que uma escola poderia ganhar ou perder posições por décimos. Em 2014, por exemplo, a escola ficou em $4^{\circ}$ lugar na disputa, perdendo o $3^{\circ}$ lugar por poucos décimos.

Diante disso, a diretoria de carnaval se reuniu para analisar as notas de cada um dos dez quesitos de julgamento. "A gente fez uma análise das notas. Aí a gente percebeu que não podemos mais perder pontos em quesitos primordiais" (notas de campo). Dessa forma, a diretoria de carnaval e a presidência da escola decidiram que era necessário dar mais atenção a alguns quesitos, contratando novos profissionais: carnavalesco (responsável pelos quesitos fantasia e alegoria), coreógrafos (responsáveis pelo quesito comissão de frente) e casal de mestre sala (MS) e porta bandeira (PB) - responsáveis pelo quesito MS e PB. A diretoria e a 
presidência percebiam que essas contratações poderiam garantir notas altas para quatro dos dez quesitos de julgamento, o que poderia fazer a diferença. Os integrantes da escola costumavam dizer: "Comissão é quesito! Casal é quesito! Carnavalesco é quesito!", ressaltando a importância desses profissionais para o desfile. Assim, mesmo acreditando que seria difícil disputar o campeonato, a escola não pretendia ficar mais uma vez em $4^{\circ}$ lugar na competição, o que foi tido como um resultado ruim.

[...] a escola escolheu estrategicamente os profissionais de destaque pra estarem somando. Eu acho que vai dar certo isso. Talvez não traga o título por falta do dinheiro ou de sorte, mas a gente vai [...] brigar. Eu acredito até que pode ficar entre as três, a não ser que aconteça essa falta de sorte, alguma fatalidade, mas se tudo for como o esperado [...] (Entrevista coreógrafos da comissão de frente)

Quanto ao carnavalesco, os diretores de carnaval relataram que observavam o trabalho do profissional contratado há alguns anos, uma vez que sempre o acharam muito talentoso. "A gente ficava impressionado! Ele [o carnavalesco] vinha conseguindo fazer bons desfiles, com qualidade de fantasia e alegoria. A gente via um monte de ferro e de repente saia um carro [...]. como é que esse cara [o carnavalesco] consegue?" (notas de campo). O que chamou a atenção foi o fato de, mesmo sem recursos financeiros e em uma escola do grupo de acesso, o carnavalesco conseguir apresentar fantasias e alegorias bem feitas.

É interessante ressaltar que antes de se dedicar ao carnaval, o carnavalesco atuava em quadrilhas juninas da Grande Vitória, também produzindo fantasias. Assim como ocorre nas escolas do grupo de acesso, as quadrilhas possuem poucos recursos financeiros para produzir sua apresentação. Portanto, o carnavalesco contratado estava habituado a lidar com situações de restrição orçamentária. Para um dos estilistas da escola, o fato de o carnavalesco ser capixaba, e não carioca (como ocorre em muitas das agremiações da Grande Vitória), também é relevante.

[...] um carnavalesco do Rio [...] os caras chegam em Vitória querendo trazer uma imposição do Rio de Janeiro [...] que não vivem de centavos, vivem de milhões. Aí quando eles chegam em Vitória, eles querem trabalhar na concepção de milhões. [...] é mais fácil você trabalhar com alguém de Vitória [...] Você consegue conversar melhor com a pessoa, [...] dentro da sua realidade. Os carnavalescos de fora [...] eles trazem uma outra concepção de custos (Entrevista destaque e estilista 1)

Assim, pude perceber que a produção de um bom desfile dependia de dinheiro, mas também de planejamento (a exemplo da estratégia de dar mais atenção a alguns quesitos de julgamento) e de um bom carnavalesco. Segundo um dos diretores adjuntos de carnaval, "quando cê sabe que uma escola não tem dinheiro e mesmo assim ela consegue fazer um bom desfile. Onde é que tá o ponto chave? É um bom carnavalesco que consegue administrar os recursos!" (notas de campo). A importância do carnavalesco na produção do desfile (especialmente quando a escola enfrenta uma escassez de recursos) também foi destacada durante as entrevistas.

[...] Antes ele [o carnavalesco] era de uma escola muito menor e com um poder financeiro muito menor ainda, e já trabalhava com muita arte, com muito estilo, com muito bom gosto. $E$ isso me encanta, porque, às vezes, o dinheiro, como eu costumo dizer, ele não é o fundamental, mas você tem que ter o poder de criação pra executar, porque nem sempre o material mais caro é que vai dar o maior visual (Entrevista destaque e estilista 2)

[...] hoje, basicamente, o que faz uma escola ser campeã ou não ser campeã é a quantidade de dinheiro que essa escola conseguiu arrecadar e como ela aplicou esse dinheiro, porque não adianta ter muito dinheiro e aplicar mal. E esse "como aplicou" vai diretamente como a diretoria trabalhou junto ao carnavalesco. É essa junção aí de recursos financeiros com o trabalho do carnavalesco na gestão desses recursos (Entrevista diretor adjunto de carnaval e diretor de comunicação)

Um pequeno trecho da entrevista com o carnavalesco também ilustra esse aspecto. Durante essa entrevista afirmei que "[...] a escola que tinha mais dinheiro, que fazia uma homenagem, que ganhou patrocínio... foi terceiro [lugar no desfile carnavalesco de 2015]!". Segundo o carnavalesco, "[...] teve o fator chuva, que atrapalhou... mas, eu acredito, que foi um carnaval mal planejado! Mesmo se não chovesse, a [escola] ia se dar mal... tava super lotada... as alegorias... a harmonia não ia conseguir, ia correr..." Eu, então, retruquei: "Então não é só dinheiro!?”. Categórico, o carnavalesco respondeu: "Com certeza não! Com certeza 
não!" (Entrevista carnavalesco). Ainda de acordo com o carnavalesco, "[...] as escolas que eu trabalhei nunca tiveram dinheiro. [...] Eles [a diretoria da escola] falaram bem assim: 'é por isso que a gente te contratou, a gente sabia que você ia conseguir fazer o carnaval sem dinheiro" (notas de campo).

É perceptível que a produção carnavalesca é marcada por contradições e ambiguidades. Se, por um lado, os integrantes da agremiação afirmam não ser possível produzir um desfile sem dinheiro, esses mesmos sujeitos entendem que "dinheiro não é tudo", afinal, é possível "driblar" essa escassez de recursos por meio de planejamento, talento, criatividade, improviso, "bom gosto", estilo, senso estético, etc. Dessa forma, na produção carnavalesca, elementos aparentemente opostos ou excludentes se complementaram. Assim, enfatiza-se as relações entre os elementos que compõem o desfile, e não a dicotomia, a necessidade de se escolher entre um ou outro (entre o dinheiro e a criatividade, e/ou entre o "bom gosto" e o uso de materiais mais simples e baratos, por exemplo).

\subsubsection{CONTRATANDO PROFISSIONAIS DO CARNAVAL}

Além do carnavalesco, dos coreógrafos e do primeiro casal de MS e PB, a escola de samba contava com outros profissionais, igualmente especializados, que suportavam a produção do desfile carnavalesco da escola.

Por exemplo, as fantasias da comissão de frente, dos destaques de chão, dos foliões dos carros alegóricos (destaque, semi destaques e composições de carro), dos casais de MS e PB e da rainha de bateria consideradas mais elaboradas e de difícil produção - foram feitas por diferentes estilistas, em ateliês localizados na Grande Vitória e no Rio de Janeiro. Devido a complexidade da produção dessas fantasias, esses profissionais foram "escolhidos a dedo" pela comissão de carnaval, sendo considerados experts na arte de "produzir fantasias".

Fotografia 9 - Comissão de frente

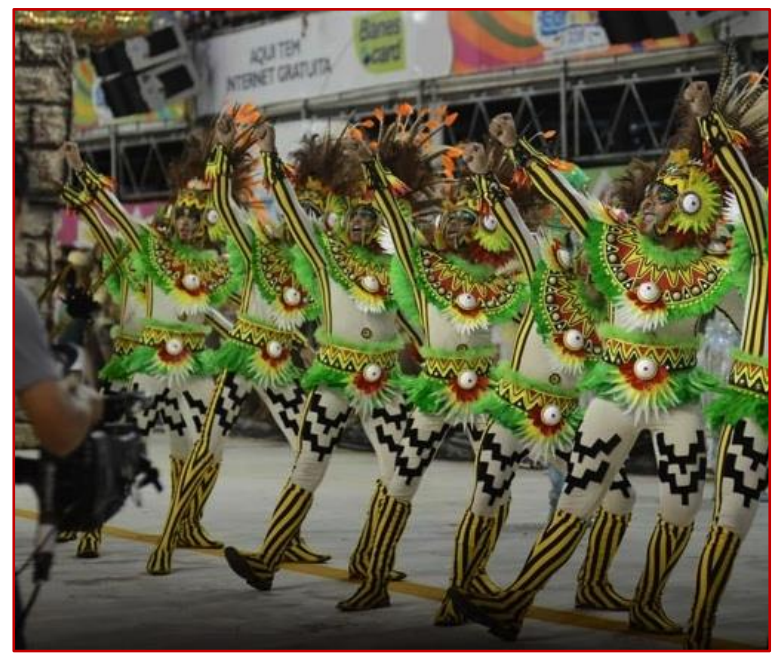

Fonte: http://www.soues.com.br

Segundo um desses estilistas, há uma espécie de "trilha de carreira" a ser seguida para que um profissional tenha o "privilégio" de confeccionar as fantasias de destaque.

Eu fiquei, se não me engano, oito ou dez anos fazendo [fantasias de] alas. De 2001 a 2010 eu fiz alas. Depois eu comecei a confeccionar destaques. [...] comecei lá no último carro [...] o desejo de todo destaque de uma agremiação é ser o destaque principal, é estar lá na frente, no primeiro carro. Eu comecei lá atrás [...] e vim pro $4^{\circ}$, pro $3^{\circ}$, passei pelo $2^{\circ}$ e vim pro $1^{\circ}$ carro (Entrevista destaque e estilista 1 )

Além disso, ao acompanhar o cotidiano de alguns dos ateliês - onde as fantasias de destaques (de chão e de carro), semi destaques e composições de carros eram produzidas -, pude perceber que os próprios estilistas eram responsáveis apenas pela confecção das peças consideradas mais complexas, geralmente das fantasias que seriam destaque ou semi destaque. As peças mais simples (como as composições de carro) eram enviadas para costureiras, que recebiam um protótipo dessas fantasias, devendo reproduzi-lo. 0 mesmo 
ocorria com a confecção da "base" das fantasias dos destaques. Por exemplo, um dos estilistas costumava usar uma espécie de collant em suas fantasias, aplicando, posteriormente, strass e pedrarias nessa peça. A confecção dos collants era terceirizada para costureiras, enquanto que a aplicação das pedrarias e das franjas de strass era feita pelo estilista. As ferragens que seriam usadas nas cabeças ${ }^{27}$ e nos esplendores (ou costeiros) também eram produzidos fora dos ateliês, por ferreiros. Segundo os estilistas, essa terceirização dá velocidade a produção das fantasias, o que pode ser evidenciado na fala de um dos entrevistados.

[...] a parte de execução eu tenho quem faz. Porque, na realidade, às vezes, não dá pra você fazer tudo, por mais que você saiba. O tempo é muito curto, então você tem que ter pessoas pra te apoiar. Mas a parte de bordado e de criação, sempre fui só eu. Só que chegou uma proporção que elas cresceram muito, eu tinha que fazer dez vestidos. Como eu faria dez vestidos? Aí tinha que ter mão-de-obra. Mas pra isso tinha que ter mão-de-obra com o nível que eu gosto, o estilo que as clientes gostam. Então a gente vai peneirando. A gente vai selecionando as pessoas que trabalham conforme você quer (Entrevista destaque e estilista 2)

Diante disso, é perceptível que a produção dessas fantasias foi suportada por uma ampla rede de costureiras, ferreiros e tantos outros profissionais (todos eles parte de arranjos materiais), sem as quais os "atores centrais" (o carnavalesco e os estilistas, por exemplo) não seriam capazes de produzir o carnaval.

Em relação aos carros alegóricos, uma das coisas mais interessantes que observei durante sua produção foi a capacidade de execução do carnavalesco e das equipes que trabalhavam no barracão (soldadores, escultores, pintores e aderecistas). Em curtos intervalos de tempo (a cada dois dias, ou até mesmo de um dia para o outro), era possível perceber que os carros ficavam visivelmente diferentes (eram soldados, ganhavam novas estruturas, esculturas e adereços, eram pintados e iluminados, etc.).

Certa vez, no barracão pesado, um dos soldadores percebeu que eu estava deslumbrada ao observar os detalhes do carro abre-alas. Ele se aproximou e me disse: "vai ganhando vida, né?!" (notas de campo), referindo-se às transformações que eu visualizava durante a produção das alegorias. Além disso, na véspera do desfile, tive a oportunidade de ir ao barracão duas vezes em um mesmo dia e pude perceber a mesma capacidade de execução. Em menos de duas semanas, quatro carros alegóricos e dois tripés foram produzidos.

O fato de o carnavalesco contar com duas grandes equipes especializadas e experientes contribuiu para essa capacidade de execução. Cada uma das equipes tinha, aproximadamente, 15 profissionais; sendo uma formada por soldadores, escultores e pintores e a outra por aderecistas. Os soldadores eram profissionais capixabas, os escultores (que também eram pintores) eram da cidade de Parintins/AM, enquanto que a equipe de aderecistas era formada por profissionais do Rio de Janeiro/RJ e integrantes da comissão de frente da escola de samba. Em cada uma das duas equipes havia um coordenador, que recebia do carnavalesco as instruções gerais de como as alegorias deveriam ser produzidas.

Os escultores também trabalhavam na "Festa do Boi de Parintins" e em outras escolas de São Paulo/SP e do Rio de Janeiro/RJ. Os aderecistas do Rio de Janeiro/RJ, por sua vez, trabalhavam na escola de samba carioca "Beija-Flor". Os integrantes da comissão de frente também trabalhavam como aderecistas. Segundo um dos coreógrafos, a maioria dos membros da comissão começou no grupo de acesso, em 2008. Do grupo de acesso, eles passaram para uma escola do grupo B e depois para o grupo especial. Devido a falta de condições financeiras das agremiações, especialmente das do grupo de acesso, os integrantes da comissão aprenderam a fazer suas próprias fantasias, assim como as alegorias que usariam em sua coreografia. Segundo um dos integrantes: "sempre sobra pra gente ajudar a fazer o que vamos usar na coreografia" (notas de campo).

[...] nas outras escolas, como não tinha recurso, a gente ajudava. Já fazia a nossa própria fantasia, davam o material e a gente ficava à noite fazendo. E aí, justamente por essa característica do grupo, a gente se ofereceu pra ajudar, até pela falta de tempo, pela falta de profissionais que a escola está, a gente montou uma equipe [...] pra estarem vindo aqui, ajudando a colar alguma coisa, cortar, essas coisas que são chatas e que não precisam de uma técnica tão aguçada pra estarem ajudando (Entrevista coreógrafos da comissão de frente).

27 É um tipo de chapéu que é colocado sobre a cabeça do folião, “alongando” a fantasia. 


\subsection{2 (RE)LENDO O ENREDO}

Até a véspera do desfile de Vitória/ES, a escola de samba não havia recebido a ajuda de custo do governo do estado e da prefeitura de Vitória. Além disso, a promessa de patrocínio por parte do prefeito da cidade homenageada (Itapemirim) também não havia se concretizado. Em função desses problemas financeiros, a diretoria da escola optou por reduzir o número de alas e de carros alegóricos, fazendo, assim, uma releitura do enredo.

Contudo, havia uma grande preocupação por parte do carnavalesco e da diretoria em manter a interpretação do enredo. Afinal, a história que seria contada na avenida não poderia ser alterada, ainda que a forma de contar essa história sofresse transformações. Essa preocupação existia pelo fato de a escola enviar antecipadamente o script do desfile à liga das escolas de samba (comumente chamada de "liga"), descrevendo sua apresentação, assim como o que cada elemento do desfile (dentre eles os carros alegóricos e as fantasias das alas e dos destaques) representaria. Tal preocupação foi verbalizada durante algumas entrevistas.

A escola inteira [...] mostra na avenida o que é o enredo. Então, eu tenho que estar dentro do que eles precisarem. [...] cada pessoa simboliza algo [...]. Por exemplo, os destaques [o casal de destaques] da última alegoria, que é uma alegoria que fala do petróleo e da fauna... o rapaz vem mais focado sobre o petróleo e ela vem [...] mais na fauna. Ela vai vir de borboleta (Entrevista destaque e estilista 2)

[...] como mudou a setorização, como saíram alas [...] você tem que incorporar toda a história [o enredo] nas demais alas que ficaram (Entrevista Diretora adjunta de harmonia)

Para que a interpretação do enredo fosse mantida havia alguns critérios que orientavam o "corte" das alas e dos carros alegóricos. O principal critério para definir o corte de uma ala ou de um carro era observar se o mesmo já estava sendo representado por outro(s) elemento(s) do desfile. Ou seja, caso uma ala (ou um carro alegórico) narrasse determinado trecho do enredo que já estava sendo representado por uma alegoria (ou uma ala), certamente essa ala (ou um carro alegórico) poderia ser cortada, conforme destaca um dos diretores da carnaval.

[...] a primeira coisa que a gente pensa é: 'como é que eu vou reduzir esse custo sem perder a qualidade [sem alterar o enredo]?' [...] a gente teve que [...] reduzir o tamanho da escola [cortar alas e alegorias]. Porque fazer uma ala é muito caro [...] E nem vai vender tudo. [...] no projeto inicial eram 25 alas. Hoje nós vamos desfilar com 17. [...] O primeiro corte [...] foi nessas alas que já tinham representação em algum lugar [em um carro alegórico, por exemplo]. (Entrevista diretor adjunto de carnaval e diretor de comunicação)

Foi justamente esse critério que orientou o corte de um dos carros alegóricos, que se referia às praias de Itapemirim. Por já haver uma ala intitulada "Sábado de Sol", essa alegoria foi substituída por um tripé com um destaque central. É interessante notar que a inclusão desse elemento humano transformou, tecnicamente, esse tripé em um carro alegórico. Ou seja, para os jurados, o "corte" desse carro não havia sequer acontecido.

Fotografia 10 - Concentração da ala Sábado de Sol

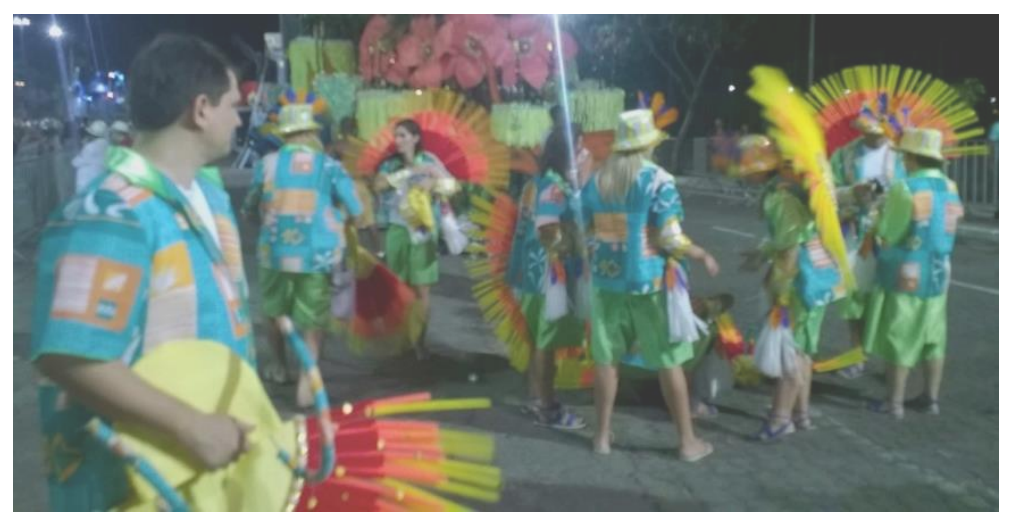

Fonte: Fotografia tirada pela autora 
Além disso, os materiais usados na produção dos carros e na confecção das fantasias das alas também foram substituído por materiais mais baratos, mas que, se bem trabalhados pelo carnavalesco, aderecistas, estilistas e costureiras, poderiam "dar o mesmo efeito" na avenida.

[...] os carros [...], eu preciso abaixar o custo, então a gente começa a pensar assim: '[...] o que eu posso fazer pra reduzir gastos, sem perder a qualidade?' [...] você ia encapar com feltro, encapa com cetim, é mais barato. Você ia ter cinco esculturas de três peixes e duas borboletas? Então fica um peixe e põe uma borboleta, completa com flores. [...] a gente tenta substituir materiais, mas que vão dar uma mesma idéia. [...] a gente também olhou as alas que [...] poderíamos baratear o custo [...] aí nós voltamos no Rio e começamos a fazer substituições. [...] essa renda custa $\mathrm{R} \$ 12$ ? Vamos trabalhar com uma que custa $\mathrm{R} \$ 4$ (Entrevista diretor adjunto de carnaval e diretor de comunicação)

Por conta de todos esses "cortes", a escola "entrou na avenida" com 17 alas, quatro carros alegóricos, dois tripés e cerca de 1.800 componentes. Ao todo, foram oito alas comerciais ${ }^{28}$, três alas coreografadas e as tradicionais alas das baianas, crianças, velha guarda, compositores, passistas e bateria. Vale ressaltar que no projeto inicial para o carnaval de 2015 a escola de samba "sairia" com 25 alas, quatro carros alegóricos (sendo o abre-alas formado por dois carros acoplados), três tripés e aproximadamente 2.500 integrantes.

[...] nós iríamos fazer um carro acoplado. [...] São dois carros que você junta em um só. Pro jurado aquilo conta como um único carro [...]. O que você ganha com o carro acoplado é em tamanho, de ser um carro gigantesco, que vai dar mais beleza, impacta mais na escola na avenida. Isso realmente foi a primeira coisa que nós cortamos. Então o abre-alas vai ser um carro menor. [...] a gente fez um orçamento de 80 mil, a gente achou caro, aí [...] cortamos algumas esculturas, cortamos alguns materiais, ele baixou pra 60 mil. Só que como a escola demorou a ter dinheiro, demorou pra trazer os profissionais, o tempo foi passando. [...] faltavam três semanas pro carnaval [...] nós tivemos que reduzir mais ainda. Então nós vamos ter uma ou duas esculturas [...] e o resto vai enfeitar o carro bem, vai deixar o carro bonito, com muitos detalhes [...] a gente meio que enxugou bem [...], pra gastar menos material, menos mão-de-obra, muito em função do tempo (Entrevista diretor adjunto de carnaval e diretor de comunicação)

A comissão de carnaval (a diretoria de carnaval e o carnavalesco) foi a grande responsável por essa (re)leitura do enredo, cujo objetivo principal era reduzir o custo de produção do desfile, sem alterar a história, o enredo que seria contado na avenida. De acordo com um dos diretores adjuntos de carnaval: "nós deixamos o nosso carnaval de R\$650 mil de material, nós baixamos pra R\$350 mil. Metade praticamente. Então de material conseguimos cortar metade, cortando ala e trocando material" (notas de campo).

Todavia, além de reduzir o custo de produção do desfile, o corte estratégico de determinadas alas também foi usado pela diretoria da escola para alavancar alguns quesitos de julgamento. Por exemplo, tradicionalmente, a agremiação conta com uma ala da comunidade, que é formada por moradores do bairro que frequentam a escola. No carnaval de 2015, por questões financeiras, essa ala foi cortada e a comunidade foi distribuída entre as demais alas comerciais da escola de samba. Além de assegurar o desfile dos moradores do bairro, essa tática contribui para o "canto da escola".

[...] por questão de custos, a escola teve que reduzir alas, [...] teve que tirar [...] a ala da comunidade, mas a comunidade não deixa de desfilar. A idéia foi [...] distribuir a comunidade em alas [...] Esse ano, como não tem coreografia, a condicionante é cantar o samba. Só vai desfilar quem estiver [...] no ensaio, cantando o samba (Entrevista diretora adjunta de harmonia).

[...] tem que saber mesclar esse pessoal todo, pra não ficar só um setor cantando [...]. Porque nas alas comerciais geralmente [...] as pessoas não cantam, não tem o compromisso [...]. Mas essas alas de casa, elas têm que vir cantando [...] o canto é um quesito (Entrevista diretora adjunta de carnaval)

${ }^{28}$ Assim como há alas destinadas à comunidade, à velha guarda, às crianças, etc., há alas cujas fantasias são vendidas, podendo ser compradas por qualquer folião que deseja desfilar na escola de samba. Tais alas costumam ser chamadas de "alas comerciais". 
[...] essas 100 pessoas que sobraram dessas [...] alas de comunidade [...] A gente vai redistribuí-las nas alas comerciais. Nós vamos colocar 10 em cada ala, pra que as alas comerciais cantem. [...] as pessoas que compram nossas fantasias nem sabem o samba [...] a gente foi muito canetado nos últimos anos [...]. já tiraram pontos por não estarmos cantando. Esse critério é harmonia. (Entrevista diretor adjunto de carnaval e diretor de comunicação)

Assim, pelo fato de a escola disponibilizar gratuitamente as fantasias para a comunidade, havia um pré-requisito para que as pessoas desfilassem. Em 2014, a condição era a presença nos ensaios, já que a ala era coreografada. Em 2015, a exigência era que as pessoas soubessem e cantassem o samba-enredo. Vale ressaltar que o quesito harmonia avalia justamente se os integrantes de cada uma das alas cantam o samba-enredo da agremiação, o que, muitas vezes, não ocorre e leva a escola a ser penalizada pelos jurados.

\subsection{PRODUZINDO CARROS ALEGÓRICOS EM 12 DIAS}

Há menos de 2 semanas do desfile carnavalesco, os carros alegóricos da escola de samba ainda estavam "no ferro", ou seja, sem nenhuma escultura ou adereço. Pude perceber que havia um certo medo de que não haveria tempo suficiente para produzir todos os quatro carros alegóricos da agremiação, afinal, o projeto inicial das alegorias previa quatro meses de trabalho no barracão. Conforme destacado, havia uma grande preocupação em manter a interpretação do enredo, já que uma das regras do regulamento do carnaval 2015 constrangia às agremiações a enviar o script do seu desfile à liga. Segundo o documento enviado, a escola de samba se comprometia a desfilar com esses quatro carros. Ou seja, caso a escola não conseguisse produzir todos as alegorias, seria penalizada pelos jurados.

Todavia, até a abertura do barracão, a escola havia informado o número de carros que entraria na avenida, mas ainda não havia especificado o que cada uma dessas alegorias representaria. Além disso, a quantidade de esculturas que compõem cada carro e o tamanho de carros/esculturas não é uma informação solicitada pela liga. Foi justamente essa interpretação do regulamento que permitiu que o carnavalesco adotasse a tática de modificar seu projeto inicial - (re)aproveitando estruturas, (re)utilizando esculturas, produzindo carros/esculturas menores e transformando tripés em carros alegóricos -, tornando-o, assim, exequível há apenas 12 dias do carnaval.

Confesso que eu, enquanto pesquisadora-integrante da escola de samba, também estava angustiada e com medo. Não apenas por correr o risco de não acompanhar a produção das alegorias, mas por ver de perto o sofrimento dessas pessoas apaixonadas pelo carnaval e por sua "escola do coração". No barracão pesado, pude observar a emoção de vários integrantes da escola, que, ao testemunharem que a produção dos carros alegóricos estava muito atrasada, "seguravam pra não chorar", verbalizando a percepção de que 2014 estava sendo "o pior ano da escola". Ao entrarem no barracão pela primeira vez (durante o ciclo carnavalesco de 2014/2015), alguns ficavam parados, observando a estrutura dos carros, como se não acreditassem no que estavam vendo.

[...] Eu penso que a escola não vai esse ano tão glamorosa quanto em outros anos. Mas isso é tudo por uma questão financeira. Não é por causa das pessoas que estão trabalhando [...] é por uma questão financeira. [...] o barracão pesado está atrasado, hoje é 14 de janeiro e está do jeito que está ainda, só nas ferragens... ainda não começaram. [...] por isso aí, a gente já fica numa tristeza muito grande. Eu não lembro de ter visto nossa escola [...] a um mês do carnaval com o barracão só nas ferragens. Tanto que eu fiquei muito triste no momento que eu entrei [no barracão pesado], dá vontade mesmo de cair pra dentro, de ajudar. Mas eu sou uma, a escola não está precisando dos meus braços, está precisando de um dinheiro que eu não tenho (Entrevista diretora adjunta de carnaval)

Conforme já destacado, diante desse cenário, foi preciso alterar o projeto dos carros alegóricos; cabendo ao carnavalesco, diretores de carnaval, soldadores, escultores e aderecistas repensar a estrutura, as esculturas e também os adereços desses carros. Ressalto, ainda, que uma das principais implicações dessa mudança radical no projeto das alegorias foi a redução do tamanho dos carros e, consequentemente, da escola de samba como um todo (que entrou na avenida sem o abre-alas acoplado e com um tripé transformado em carro alegórico). 
Durante um dia de trabalho no barracão pesado, o carnavalesco afirmou: "eu [...] comecei a olhar o que [...] dava pra aproveitar [estrutura dos carros e esculturas]. Eles iam dar isso aqui tudo [esculturas] pros outros [outras agremiações]. Se dessem... Não ia ter o que fazer..." (notas de campo). Diante disso, é perceptível que a mudança no projeto das alegorias exigiu criatividade, flexibilidade, capacidade de improvisação e senso estético refinado por parte dos atores envolvidos na concepção e na execução dos carros alegóricos. O que não requer, necessariamente, o uso de materiais caros ou novos, e sim a capacidade de "transformar 'lixo' em luxo" (notas de campo). Ou seja, a habilidade desses atores em utilizar materiais mais simples e baratos, ou, até mesmo, de desfiles anteriores, assim como de combinar cores e zelar pelo acabamento, assegurando um efeito visual às esculturas e aos carros alegóricos, impactando visualmente o público e os jurados.

Foi assim que emergiram atividades centrais para o fazer estratégia da escola de samba, atividades em torno das quais a produção dos carros alegóricos aconteceu: (re)aproveitando a estrutura dos carros e (re)utilizando esculturas.

\subsection{1 (RE)APROVEITANDO A ESTRUTURA DOS CARROS ALEGÓRICOS}

Para que a produção das alegorias pudesse ser iniciada, a escola precisava comprar ferragem, madeira, isopor, cola, pregos, tintas e adereços (tecidos, pedrarias, passamanarias, etc.). Além disso, a mão-de-obra que executaria a produção dos carros alegóricos (ferreiros, escultores, pintores e aderecistas) também precisava ser contratada. Por conta da crise financeira, a agremiação precisou levantar recursos - com a bilheteria e a venda de bebidas dos ensaios, promovendo feijoadas e com seus integrantes, que doaram parte do material que seria usado na produção das alegorias - para obter materiais e contratar mão-de-obra. Isso fez com que o barracão pesado fosse "aberto" apenas na segunda quinzena de janeiro de 2015, duas semanas antes do desfile.

O carnavalesco e a diretoria de carnaval optaram, então, por reaproveitar a estrutura de ferro dos carros alegóricos do carnaval de 2014, fazendo apenas pequenas modificações. Assim, o projeto inicial dos quatro carros alegóricos do desfile de 2015, que havia sido feito pelo carnavalesco e estava representado em quatro maquetes de isopor, não foi seguido. Durante as duas semanas em que os carros alegóricos foram produzidos, esse projeto foi modificado inúmeras vezes (mantendo-se a produção de quatro carros), sem que outras maquetes fossem feitas.

Os projetos dos carros alegóricos já mudaram umas quatro vezes [...] O primeiro projeto eram aquelas maquetes, que estavam ali em cima. Aquilo lá eram alegorias pra serem feitas em quatro meses, não em quatro semanas, né. Então agora a gente tem duas semanas pra fazer. Então assim, a gente já cortou muita coisa. A ideia basicamente é a mesma, de quatro carros, mas a gente foi mudando a concepção. Então ele tem essa maleabilidade né, que hoje o carnaval precisa ter. Porque assim, quando começa o carnaval, você faz uma projeção, mas durante o processo [...] ninguém imaginava que o governador ia cortar verba, ninguém imaginava que a verba da prefeitura ia demorar pra sair (Entrevista diretor adjunto de carnaval e diretor de comunicação)

Fotografia 11 - Maquete do carro abre-alas

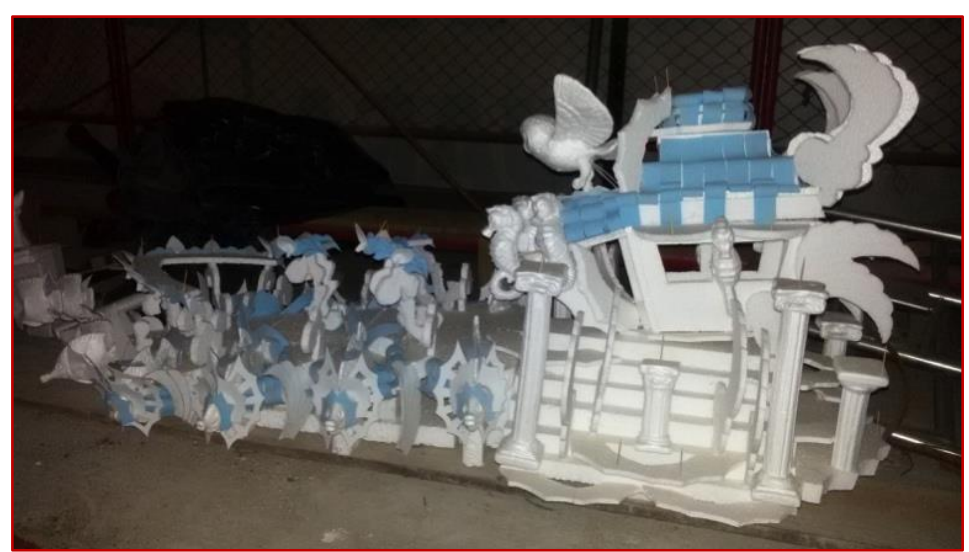

Fonte: Fotografia tirada pela autora 
A produção do segundo carro alegórico, intitulado "Águas que abençoam e alimentam a fé", ilustra bem a atividade "(re)aproveitando a estrutura dos carros alegóricos". Essa alegoria representava a igreja matriz da cidade de Itapemirim.

Ao acompanhar o dia-a-dia do barracão identifiquei que um dos carros alegóricos de 2014 representava a igreja do Senhor do Bonfim, uma vez que o enredo daquele ano falava sobre a Bahia. Para o carnaval de 2015, a estrutura de ferro da igreja e dos altares seriam mantidas, representando a Igreja de Itapemirim. Dessa forma, boa parte da estrutura desse carro foi conservada, sem que a nova história a ser contada na avenida durante o desfile de 2015 fosse prejudicada.

Fotografia 12 - Alegoria do carnaval de $2014 \quad$ Fotografia 13 - Alegoria no 2 sendo finalizada

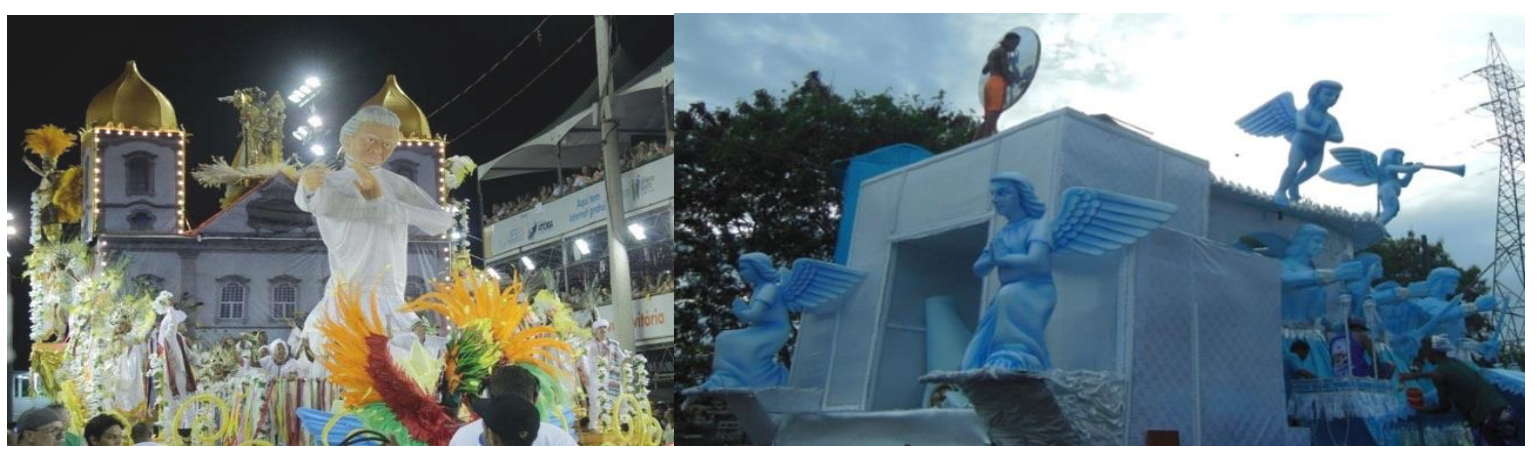

Fonte: http://www.soues.com.br

Fonte: Fotografia tirada pela autora

Também pude observar o aproveitamento das estruturas dos carros na produção das demais alegorias. Por exemplo, alguns carros tiveram sua estrutura inicial apenas complementada com mais ferragem soldada; em outros casos, a estrutura de uma alegoria foi retirada e soldada em um segundo carro alegórico. Dessa forma, ambos os carros eram transformados por meio da reutilização de estruturas. Comparada à produção de novos carros alegóricos, a tática de reutilização de estruturas já existentes é mais barata e rápida.

\subsection{2 (RE)UTILIZANDO ESCULTURAS}

De acordo com o regulamento do carnaval 2015, não é permitido que uma agremiação empregue em seu desfile esculturas ou carros alegóricos notoriamente já utilizados por ela mesma em desfiles anteriores. Todavia, apesar de não ser uma regra explicita, ou formalmente apresentada no regulamento do carnaval, diferentes escolas podem trocar esculturas, o que, inclusive, é uma prática comum entre as agremiações da Grande Vitória. Outra opção seria fazer uma "releitura" das esculturas já utilizadas, descaracterizando-as (para que os jurados não percebam que esses elementos já foram usados em desfiles anteriores), o que também não é uma regra explícita/formal e exige muita criatividade, flexibilidade, capacidade de improvisação e senso estético refinado por parte do carnavalesco e dos escultores, não sendo, portanto, uma prática comum.

Vale ressaltar que ao enviar o script do seu desfile à liga, as escolas relatam o que cada carro alegórico representa em relação ao enredo que se pretende contar na avenida. Todavia, não é necessário descrever as esculturas que irão compor esse carro, nem mencionar se as mesmas já foram ou não usadas em carnavais passados; o que permite que carnavalesco e escultores usem todo seu know-how durante o processo de criação e (re)aproveitamento de esculturas.

Diante da já mencionada crise financeira e há apenas duas semanas do desfile, reutilizar esculturas foi uma das atividades que orientou a produção dos carros alegóricos da agremiação. No barracão havia várias esculturas usadas em carnavais passados: cisnes negros, anjos cor de rosa, baianas, escravos, orixás e uma cabeça de coruja. Escultores trabalhavam, lixando peças de isopor e retirando as camadas de papelão e tinta que cobriam as esculturas usadas no carnaval de 2014.

De modo ilustrativo, destaco que foi muito interessante observar a produção do $2^{\circ}$ carro alegórico, que representava a Igreja de Itapemirim. Todas as esculturas que estavam nesse carro foram retrabalhadas, mas o que mais me encantou foi o processo de criação dos anjos azuis maiores. Em 2014, havia um carro com 
esculturas de orixás; em 2015, esses mesmos orixás foram transformados em anjos. As pernas dos orixás deram lugar a uma saia, que foi adereçada com tecido azul. Os troncos dos orixás foram encaixados nessas saias. Os rostos das esculturas foram recortados, restando apenas suas cabeças. Novos rostos foram esculpidos e encaixados nas cabeças dos orixás. Por fim, os orixás ganharam asas, espadas e foram pintados de azul.

Fotografia 14 - Escultura do carnaval 2014

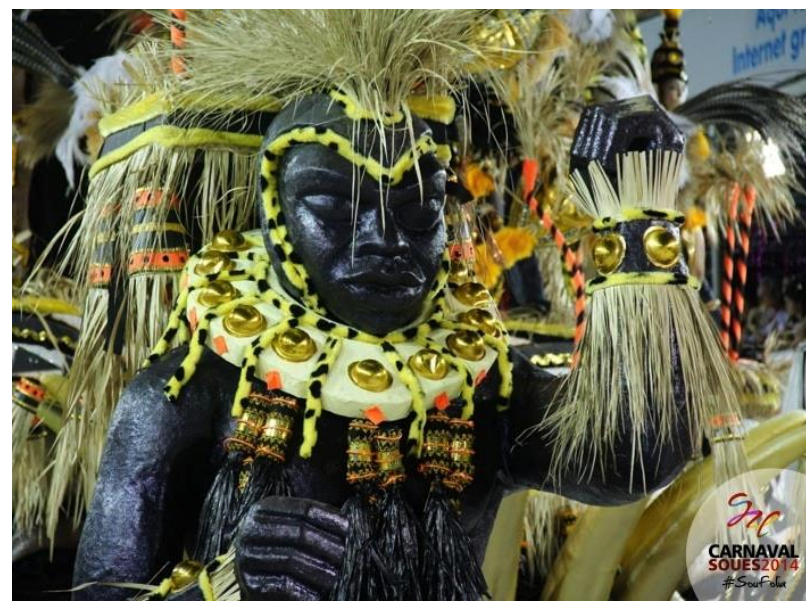

Fonte: http://www.soues.com.br
Fotografia 15 - Escultura da alegoria no 2

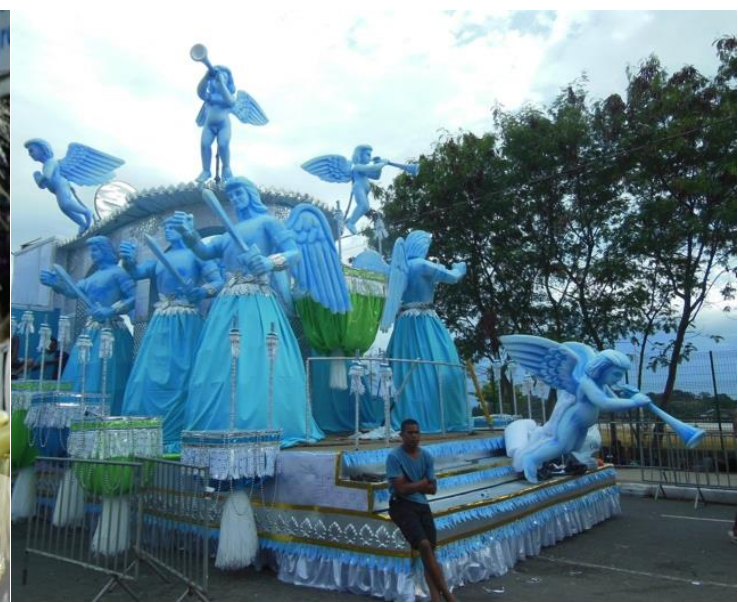

Fonte: Fotografia tirada pela autora

Também observei a reutilização de esculturas na produção dos demais carros da agremiação. Além disso, houve intensa troca de esculturas entre diferentes escolas, assim como outros exemplos de "releitura" de esculturas já utilizadas em carnavais anteriores. Quando comparada ao processo de esculpir novas esculturas, a tática de reutilização de esculturas (seja por meio da troca, ou da releitura) também é mais barata e rápida.

\subsection{3 “TAMANHO NÃO É DOCUMENTO!"}

Um dos traços do carnavalesco contratado era o uso de uma mistura de cores. Vale ressaltar, que as fantasias e os carros alegóricos projetados para o carnaval 2015 eram bem coloridos. De acordo com alguns integrantes da escola, esse colorido é a assinatura do carnavalesco. Para alguns, nos últimos anos, o carnaval da escola estava "muito tradicional", uma vez que as alas e os carros alegóricos eram majoritariamente de uma mesma cor, com um suave dégradée de cores entre os setores da escola (ver setorização).

Além da mistura de cores, havia uma preocupação por parte do carnavalesco em relação aos detalhes, ao acabamento dos carros alegóricos e das fantasias. Durante as observações no barracão, era comum ouvir a seguinte afirmação: "Não adianta ter carro grande e mal acabado". Por exemplo, há apenas dois dias do desfile, observei que o carro abre-alas estava praticamente pronto. No carro havia uma escultura de cabeça de coruja, que estava sendo pintada por um dos escultores de Parintins. A coruja, que tinha barbatanas (por estar em um carro que representava as águas de Itapemirim), estava ficando colorida, com uma mistura viva e exuberante de azul, roxo e amarelo. Todavia, o carnavalesco afirmou que ainda faltava um "tcham" (detalhes do acabamento), dizendo que não sabia ainda o que iria fazer, mas que estava pensando.

No dia seguinte, voltei ao barracão e pude observar que pedras e confetes prateados e azuis brilhantes foram colocados na coruja, que também ganhou detalhes pretos (pintura) nos olhos, no bico e na testa. No desfile, pude perceber mais um detalhe, havia uma pequena máquina instalada entre a cabeça e a barbatana da escultura, fazendo com que a coruja do abre-alas soltasse bolhas de sabão. Esse cuidado do carnavalesco em relação ao acabamento dos carros também foi explicitado em uma de suas falas:

A ideia era tentar primar no acabamento, pra tirar imperfeição [dos carros e das esculturas], pro pessoal [jurados e público] ver que o carro foi bem feito. Também teve as bandeirinhas... que ficaram colando até... Também teve os espelhos, as pedras... quem vê, vê que teve esmero, que foi bem feito, que tivemos paciência e 
tempo pra fazer. Se bem que tempo a gente não tinha, mas foi! E o jurado olha tudo isso! Lógico! Então, não adianta aquela escultura de sei lá quantos metros de altura. Portela, 23 metros de altura. Não!!! Se o carro tiver mal acabado, vai ficar ruim. Eu me espelho muito no trabalho da Rosa Magalhães [uma carnavalesca carioca]. Se ela fizer uma carruagem, você pode entrar dentro, que a carruagem vai estar até o teto, lá onde ninguém vai ver, vai estar tudo bem acabado (Entrevista carnavalesco)

Diante disso, percebi que, por meio de uma mistura de cores e de um acabamento cuidadoso, o carnavalesco buscava compensar o fato de a escola ter esculturas e carros alegóricos pequenos; sendo essas táticas exemplos de atividades importantes para o fazer estratégia da escola. Afinal, "tamanho não é documento!".

Você pode estar com o carro gigantesco todo bem acabado e eu posso estar com um menorzinho todo bem acabado. A nota tem que ser a mesma. Você não pode ver pelo lado da grandiosidade, tem que equiparar as coisas. Agora, você pode olhar, passou um carro aqui bem melhor do que o deles. Aí você pode botar em julgamento isso. Poxa, o carro dela está melhor do que o dela. Está mais bem acabadinho [...] (Entrevista mestre de bateria)

[...] é fazer o "bê-a-bá" certinho. Se você faz o seu dever de casa, todos os quesitos representam bem [...] e uma outra escola que é maior, está cotada pra ganhar, erra em algumas questões ou tem [...] falta de organização, acaba que uma escola como a nossa, que está pequenininha, está compacta, mas fez o seu trabalho direitinho [...] Todos os quesitos representaram muito bem. Então assim, carnaval se define na avenida, não tem como falar que o carnaval de fulano de tal vai ganhar esse ano. Não tem como. Então não precisa ter dinheiro pra fazer um bom trabalho. Ajuda o dinheiro, mas [...] o [carnavalesco] tem essa característica de fazer um trabalho muito bem plástico, muito bem acabado. Então a gente sabe que os carros vão vir menores, têm uma estrutura menor, só que ele tem esse lado de bem acabado. Então a gente tem um ganho aí (Entrevista coreógrafos da comissão de frente).

\section{4 (RE)PRODUZINDO FANTASIAS}

As fantasias confeccionadas para o carnaval de 2015 podem ser aglutinadas em dois grandes grupos: fantasias das alas e fantasias dos destaques. As fantasias das alas foram reproduzidas por diversos ateliês, cujos estilistas e costureiras baseavam-se nos protótipos feitos pelo carnavalesco. Já as fantasias dos destaques foram produzidas, ou seja, os estilistas responsáveis por sua confecção não se basearam em protótipos anteriormente entregues pela escola; guiando-se apenas por croquis (desenhos que ilustram a leitura da fantasia em relação ao enredo, assim como a combinação de cores que deveria ser usada) disponibilizados pelo carnavalesco.

\subsubsection{DESCENTRALIZANDO A REPRODUÇÃO DAS FANTASIAS DAS ALAS}

No ciclo carnavalesco de 2014/2015 a diretoria de carnaval e o carnavalesco optaram por produzir as fantasias das alas de modo descentralizado, ou seja, em diversos ateliês de diferentes estilistas, que ficavam espalhados pela região metropolitana da Grande Vitória (nas cidades de Serra, Vitória e Vila Velha). Dessa forma, não havia um grande barracão, comumente chamado de "barracão leve", onde estilistas e costureiras trabalhassem juntos. Trabalhar de modo descentralizado dá velocidade à produção das fantasias; além de ser mais econômico e prático, uma vez que a diretoria de carnaval não precisa se preocupar com o transporte e a alimentação dos profissionais que trabalhariam nesse barracão leve.

Para que as fantasias das alas pudessem ser reproduzidas pelos ateliês, coube ao carnavalesco confeccionar seus protótipos, que serviriam de modelo para os estilistas. Segundo o carnavalesco: "Eu só monto os protótipos, daí eles [os estilistas dos ateliês de reprodução] se viram. Não quero nem entrar aqui [no ateliê] depois..." (notas de campo). Além disso, todo o material (tecidos, placas, ferragens, pedrarias, plumas, aviamentos, cola, etc.) a ser empregado na reprodução das fantasias foi comprado pela escola e entregue para os ateliês. Cada um dos protótipos também tinha um molde (feito com uma espécie de papelão), cuja função 
era auxiliar estilistas e costureiras a cortar as peças de tecido das fantasias, assim como controlar a quantidade de material que deveria ser utilizado.

Mesmo assim tem costureira que sempre diz que falta material, pra ficar com o material. Daí você volta no ano que vem e ela quer te vender o material. Aí tem que cortar [deixar de trabalhar com esse ateliê], não tem jeito... (Entrevista carnavalesco)

Quando comparados às fantasias que foram reproduzidas e comercializadas, os protótipos eram mais luxuosos - com mais penas, esplendores maiores e detalhes de placas, o que facilitava a venda das alas comerciais. De acordo com vários integrantes e foliões, pessoas que acompanham o carnaval há décadas, a diferença observada entre os protótipos e as fantasias reproduzidas é algo comum, ocorrendo, inclusive, em outras escolas de samba.

Fotografia 16 - Protótipo ala Ouro Negro

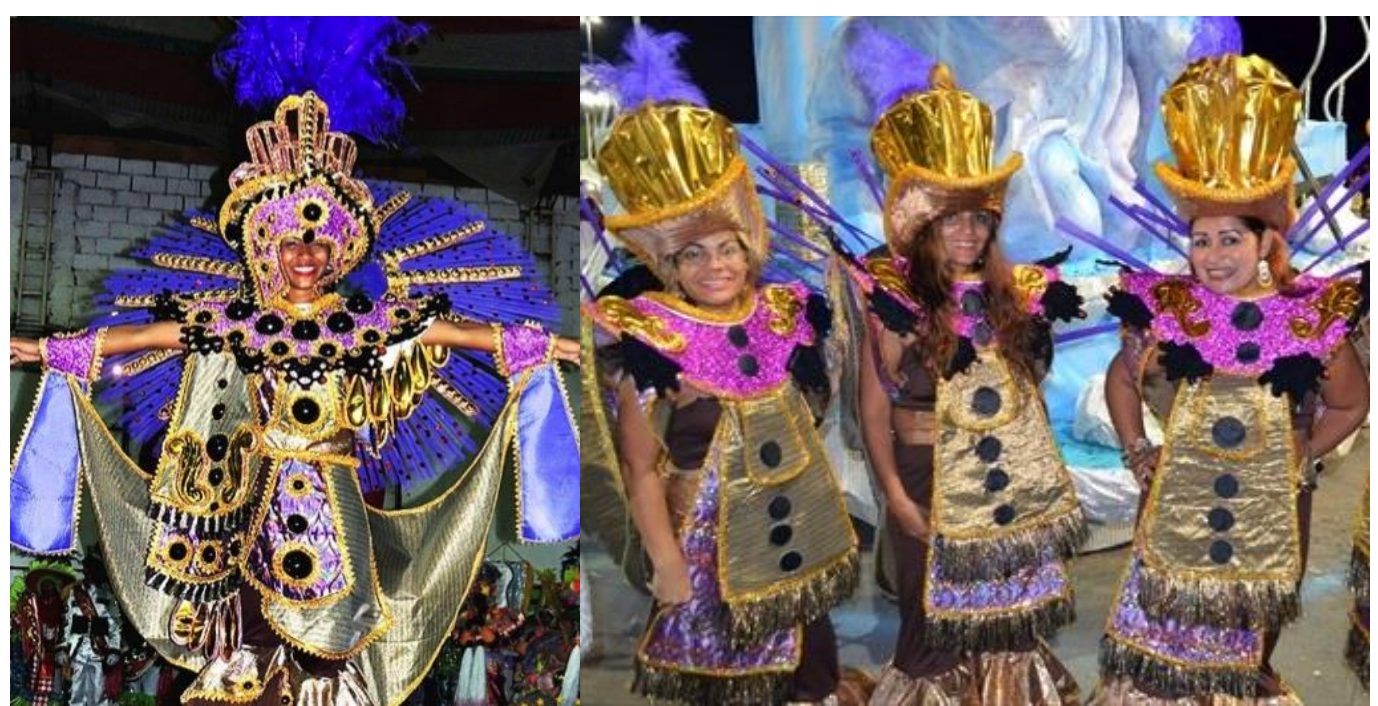

Fonte: Fotografia tirada pela autora
Fotografia 17 - Fantasia ala Ouro Negro

Fonte: Fotografia tirada pela autora

Todavia, devido à restrição orçamentária, o carnavalesco teve que lidar com um corte ainda maior, utilizando na reprodução dos protótipos materiais muito mais simples do que o usual. Por exemplo, chapéus de palha foram empregados no lugar de ferragens (material comumente usado para confeccionar as cabeças das fantasias), penas sintéticas substituíram plumas, e tules enrolados alongaram os costeiros, possibilitando o uso de menos ferragem.

O [carnavalesco] trabalha muito, é incrível [...] e com coisas que são de um valor muito pequeno, mas de um visual muito grande. Se você observar as fantasias que ele criou, tem costeiros lindíssimos, que são feitos de tule, com varinha dentro (Entrevista destaque e estilista 2)

É interessante notar que alguns desses materiais, como o chapéu de palha, são comumente usados nas quadrilhas juninas, contexto no qual o carnavalesco atuou antes de ingressar no carnaval. Conforme mencionado, assim como ocorre nas pequenas escolas, as quadrilhas possuem poucos recursos financeiros para produzir sua apresentação.

Além do uso de materiais mais simples, um dos traços do trabalho do carnavalesco era o colorido de suas fantasias e alegorias. De acordo com um dos estilistas da escola, o carnavalesco "grita" por meio de uma mistura de cores, sendo mais vivo e vibrante, ao mesmo tempo em que usa como base as cores da escola - o verde, o vermelho e o branco.

Caramba, ele [o carnavalesco] colocou roxo, azul, amarelo, lilás numa fantasia só! Trabalhar com cor não é pra qualquer um, não é qualquer um que mistura as cores e fica bonito, pode virar uma miscelânea... (Entrevista destaque e estilista 2) 


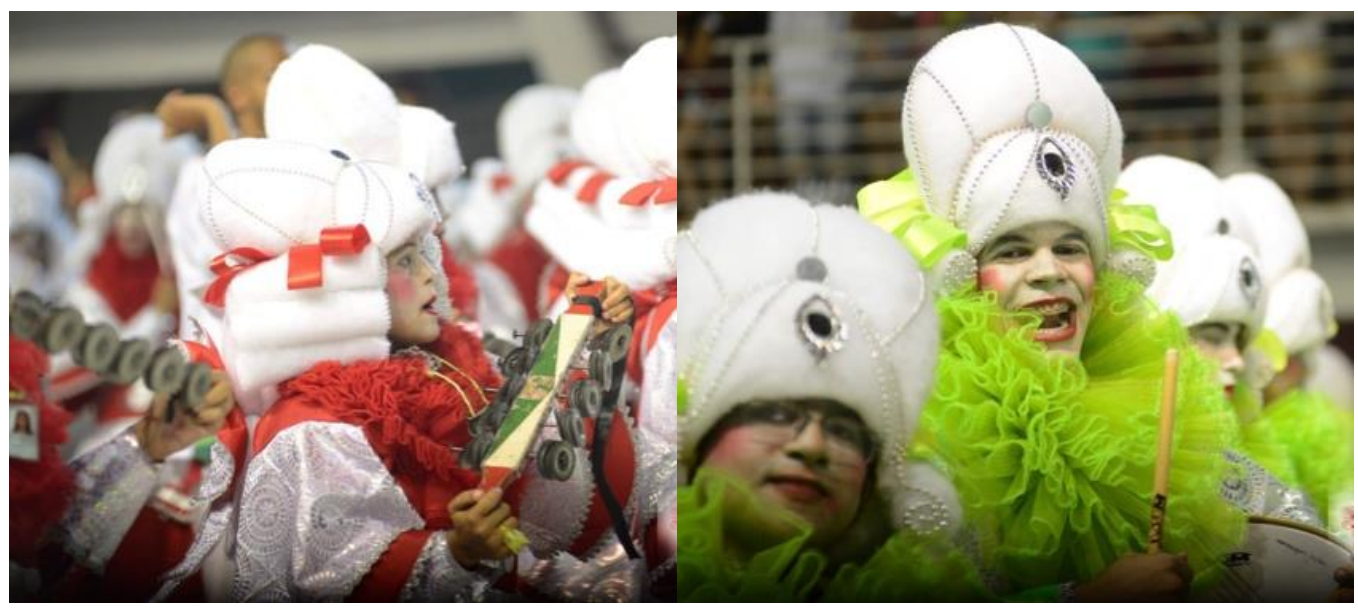

Fonte: http://www.soues.com.br

De acordo com o carnavalesco, esse colorido também é uma forma de compensar o uso de materiais mais simples, uma vez que por meio dessa mistura de cores é possível trazer luxo para avenida, impactando visualmente o público e os jurados. Por exemplo, apesar de usar materiais considerados simples (como placas, arame, tule e penas sintéticas), a fantasia da ala Ouro Negro era percebida como muito luxuosa, justamente por misturar as cores amarelo, dourado e roxo; sendo, inclusive, uma das mais vendidas durantes os ensaios gerais de domingo.

[...] quando se trabalha com uma escala monocromática, é gritante quando uma fantasia não está completa. Com o colorido o cara [o jurado] não vai nem perceber. Quem tava lá no meio... você viu tudo... por isso você notou [a diferença entre os protótipos e as fantasias]. Mas quem não conhecia, passou batido! Tanto é que as fantasias tomaram [nota] dez [na apuração do desfile carnavalesco]! (Entrevista carnavalesco)

Além disso, muitos dos materiais usados na reprodução das fantasias das alas eram materiais sobressalentes de carnavais passados, que estavam guardados no barracão leve da escola.

Fotografia 20 - Comissão de frente de 2014

Fotografia 21 - Ala Canaviais

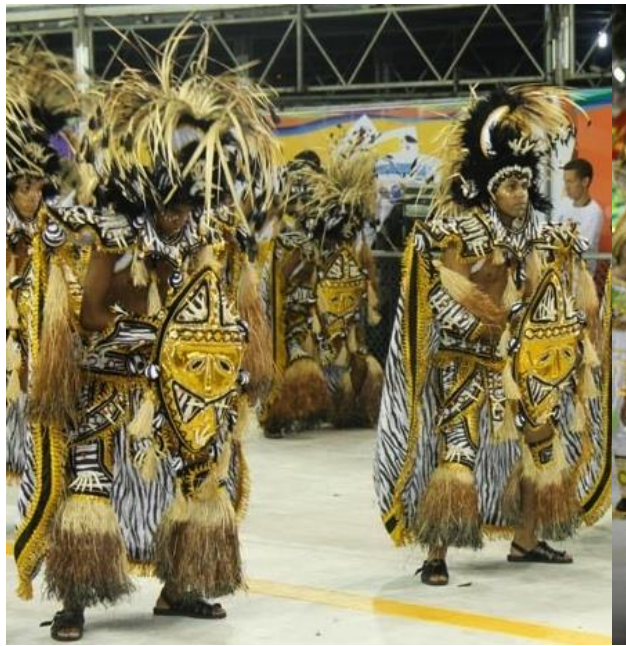

Fonte: http://www.soues.com.br

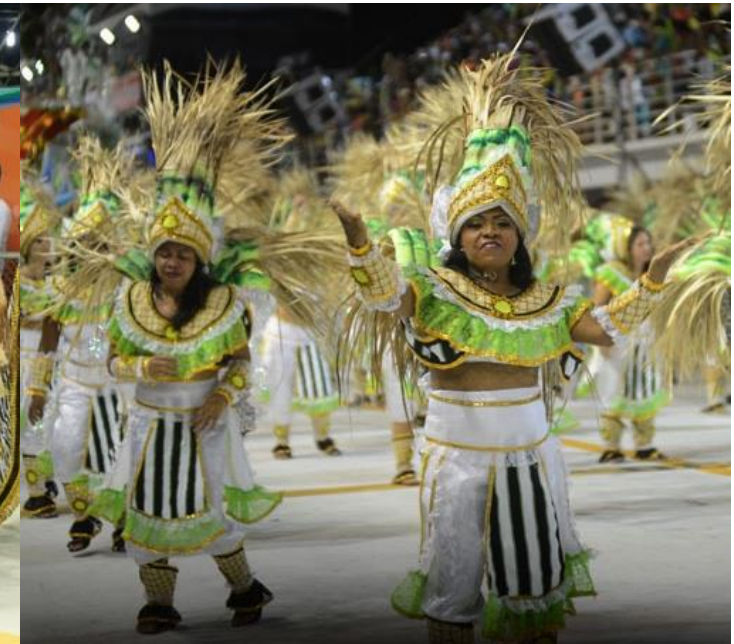

Fonte: http://www.soues.com.br

O colorido das fantasias permitiu que o carnavalesco pudesse reaproveitar esses materiais, combinando diferentes tons, mesmo que, inicialmente, a ideia fosse utilizar adereços diferentes. 


\subsubsection{REPAGINANDO FANTASIAS}

As fantasias dos destaques (de chão e dos carros alegóricos), da rainha de bateria, da comissão de frente e dos casais de MS e PB (todas elas consideradas mais elaboradas e de difícil produção) foram feitas em ateliês localizados na Grande Vitória e no Rio de Janeiro. De todo modo, a produção dessas fantasias também aconteceu de modo descentralizado. Todavia, a descentralização não ocorreu somente devido a economia de tempo e dinheiro, mas também, e principalmente, pelo fato dos profissionais escolhidos serem considerados especialistas na arte de produzir fantasias, no "fazer fantasia".

Dessa forma, diferente do que aconteceu com as fantasias das alas - que tiveram um protótipo produzido pelo carnavalesco, para posteriormente serem reproduzidas -, as fantasias dos destaques foram produzidas por diferentes estilistas. Esses profissionais receberam croquis do carnavalesco, sendo livres para fazer uma (re)leitura própria das fantasias que iriam produzir.

[...] você faz uma interpretação do desenho, do croqui que ele [o carnavalesco] te passa [...]. Olha, ele me deu o croqui e me deu com uma escala de cores, "eu preciso dessa cor, dessa cor e dessa cor". Não necessariamente a cor tem que estar aqui, aqui e aqui. Eu que vou trabalhar essa interpretação das cores. [...] Eu só não posso mudar a ideia [a leitura da fantasia em relação ao enredo], o cromatismo de cores que tem (Entrevista destaque e estilista 1)

[...] nós temos pares [de fantasias de destaque], casais. Então ele [o carnavalesco] deu um esboço, [...] fez os desenhos de um e falou: Em cima desse [croqui feminino] vai ter que criar o masculino [a fantasia masculina], em cima do masculino [do croqui masculino] tem que criar o feminino [a fantasia feminina] (Entrevista destaque e estilista 2)

Além disso, a escolha dos materiais das fantasias também fica a critério dos estilistas, e não do carnavalesco, dependo do estilo de cada um desses profissionais. Por exemplo, ao acompanhar o cotidiano de ateliês que confeccionavam fantasias de destaques pude perceber que um estilista preferia usar franjas de strass, enquanto outro utilizava capim dourado ${ }^{29}$ e renda.

[...] a minha inspiração é constante. Eu tenho um restaurante japonês e a gente foi comprar, o rapaz levou um polvo pra mim. E era um polvo imenso, lindo, inteiro. $\mathrm{E}$ aí quando pôs na mesa, tinha aqueles tentáculos e dentro tinha um monte de bolinhas. Eu olhei para aquilo e falei: "Gente, isso dá um vestido". Então assim, igual você olha uma casa de abelha [...] eu falo: "Nossa, que coisa linda, isso eu vou aproveitar". Então são as coisas mais bobas, eu não tenho muito tipo, "ah, o que eu vi de Paris!". Claro que a gente gosta, é lindo, pesquisa é sempre fundamental. Mas muitas das vezes é no cotidiano, na coisa mais boba do mundo (Entrevista destaque e estilista 2)

Também pude observar que muitos dos materiais usados por esses estilistas eram, na verdade, materiais (re)utilizados, de carnavais passados.

[...] você vai guardando material, você vai criando um acervo. [...] pra você ter uma grande fantasia, você precisa de um acervo legal. O que mais gasta numa fantasia são as penas, você tem que ter um acervo de penas. [...] você tem que reciclar uma coisa de uma fantasia, tirar e tal... por mais que você compre, você pode estar reutilizando [materiais] de outras fantasias [...].Você tem que ir a São Paulo comprar material mais alternativo, mais barato. Mas a gente também precisa ter um acervo de algumas coisas [penas e strass, por exemplo] mais caras (Entrevista destaque e estilista 1)

A fantasia de um destaque de um dos carros alegóricos, por exemplo, foi repaginada pelo próprio carnavalesco, que utilizou como base a fantasia trajada pelo Mestre Sala (do primeiro casal de MS e PB) no carnaval de 2014.

${ }^{29}$ Palha de cor dourada com a qual se faz pulseiras, brincos, peças de decoração, etc. 


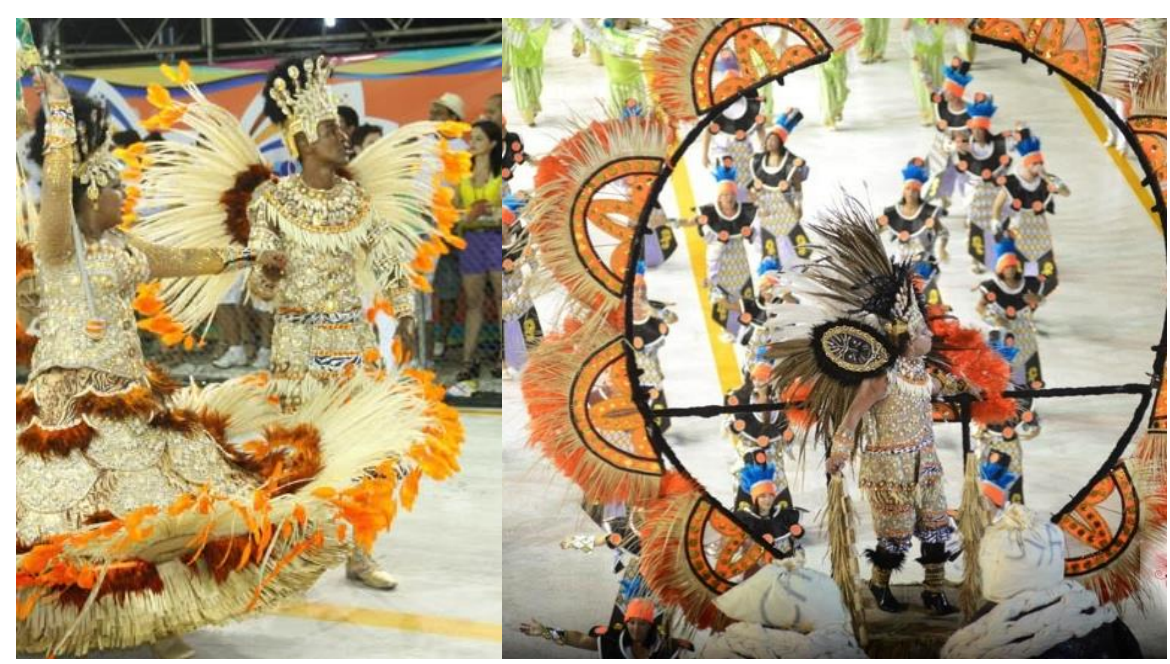

Fonte: http://www.soues.com.br

Fonte: http://www.soues.com.br

Diante disso, "tudo é uma repaginação", uma releitura, já que nenhuma fantasia seria feita "do zero", ou seja, sem a utilização de elementos mais clássicos (como as penas de faisão ou a franja de strass), de materiais já empregados em outras fantasias ou sem que o estilista responsável por sua confecção se inspirasse em trabalhos já realizados.

[...] tudo é uma repaginação [...] no mundo do samba [...] eu já vi de tudo. Não venha dizer que você vai criar aquilo, porque a franja já existe há não sei quantos milhões de anos, o brilho é fundamental, o faisão antigamente era só pra quem tinha muito dinheiro, hoje já está muito mais acessível. É trabalhar com bom gosto em cima do sonho de cada um (Entrevista destaque e estilista 2)

Além de reaproveitarem materiais usados em fantasias de carnavais anteriores, os estilistas também adquiriam novos materiais, em estabelecimentos comerciais do Rio de Janeiro/RJ (localizados no centro da cidade, na Uruguaiana), de São Paulo/SP (situados na Rua 25 de Março) e até mesmo pela internet (em sites chineses). O preço costumava ser o fator determinante na decisão de onde comprar esses matérias. Segundo um dos estilistas, na Grande Vitória, penas, tecidos, pedrarias e aviamentos podem custar até 10 vezes mais.

Eu sempre costumo viajar e essas minhas viagens é pra pesquisa, eu adoro trabalhar em relação a isso. Eu vou pesquisar material, pedraria, o que tem de novo no mercado e isso é interessante, porque quando a cliente chega pra mim, eu já sei o que eu posso ou não usar pra ela, o que eu tenho de novidade ou não. Normalmente, eu trago amostras [...] como eu tenho já fornecedores de muitos anos [...]. Eu também sou muito louco, porque se eu passar em algum lugar e eu ver algum tecido bonito, eu compro. Independente de 'ah, mas pra quem?' Não sei, mas vai chegar a alguém (Risos). Então eu fico sempre antenado em tudo (Entrevista destaque e estilista 2)

Também pude observar que uma das grandes preocupações dos estilistas era com o acabamento das fantasias, uma vez que, segundo eles mesmos, "a fantasia tem que acontecer". Ou seja, durante o desfile carnavalesco, os materiais utilizados na produção das fantasias não poderia se desprender de sua base, se soltando, "despencando pela avenida" (o que faria com que a escola fosse penalizada pelos jurados).

Quando a pessoa está desfilando, aquela cola que está encostada [...] a tendência é ele ir soltando, a pessoa passar o dedo e tal. Aí o paetê [...] vai soltando [...] o material que você está usando vai despencando avenida afora. Isso conta no quesito fantasia. Fantasia mal elaborada, mal trabalhada [...] Ela [a costureira] estava fazendo sem o contato [sem passar cola nas duas peças que estavam sendo coladas]. Aí eu comecei a puxar [...] Ai eu fui desmanchando [...] 'Agora você vai passar a cola no paetê e não precisa mais passar a cola naquela peça ali, porque ela já está com cola' (Entrevista destaque e estilista 2) 
Todavia, uma das coisas que mais chamou minha atenção foi o fato de as fantasias dos destaques não serem diretamente um quesito de julgamento. Durante uma das minhas primeiras entrevistas, fiz a seguinte pergunta a um estilista: "Esse trabalho que você faz está ligado a quais quesitos de julgamento?". Para minha surpresa, essa foi sua resposta:

Então, isso que é muito engraçado. Olha, os destaques, as rainhas, elas gastam rios de dinheiro e eles não têm importância nenhuma, a não ser luxo. Porque em notas, que eu acho que é isso que você quer chegar, nós não somos quesitos. [...] Elas fazem parte do geral [da avaliação geral do quesito fantasia]. Na realidade [...] se elas estão lindas, elas passam, se elas estão feias, elas são canetadas, mas elas não servem de nada. [...] Porque o único quesito [específico] de roupa que é avaliado é mestre-sala e porta-bandeira. Rainha de bateria não é avaliada, madrinha de bateria não é avaliada, destaques [...] não são avaliados. [...] Se tiver perfeito, bem, obrigado [...] (Entrevista destaque e estilista 2)

Dessa forma, não há um quesito explicito e formal que avalie as fantasias dos destaques. Entretanto, caso ocorra alguma problema com algum destaque (caso uma roupa "despenque pela avenida", por exemplo), a escola pode perder pontos no quesito fantasia, que avalia o conjunto de fantasias da escola como um todo. Contudo, mesmo não sendo um quesito específico, pude perceber a importância dos destaques para a agremiação. Primeiramente, os destaques são responsáveis por "levar luxo para avenida", o que é esperado pelos integrantes da escola de samba, pelo público e até mesmo pelos jurados. Além disso, durante o desfile carnavalesco, os destaques de chão também têm a "função" de preencher eventuais espaços entre as alas e os carros alegóricos, ajudando no quesito evolução.

[...] a gente leva luxo de graça, porque é a gente que se banca e [...] de uma certa forma preenche a frente da alegoria. [...] o destaque de chão não é só um bibelô de luxo, ele tem uma função. [...] Se existe uma ala na frente do carro e existe uma alegoria, se por ventura aquela alegoria travar ou acontecer alguma coisa que ela tiver que parar, a ala se esvai, vai ficar um buraco entre a ala e o carro. Isso é canetado, não pode ter buraco na avenida. Onde entra o destaque? Pra preencher o espaço, pra sambar, pra evoluir! [...] (Entrevista destaque e estilista 2)

É interessante notar, ainda, que as fantasias das alas e dos destaques (assim como os carros alegóricos) foram, durante o desfile carnavalesco, verdadeiras extensões dos corpos dos integrantes e dos foliões. Dessa forma, não faz sentido, não é possível falar de carnaval ou da escola sem ressaltar o pavilhão verde, branco e vermelho; as fantasias coloridas e luxuosas; os carros pequenos, mas bem acabados; os instrumentos da bateria e outros tantos arranjos materiais enquanto extensões dos corpos dos integrantes e dos foliões da agremiação, enquanto elementos que constituíram o contexto no qual a escola de samba aconteceu. Afinal, o que seria da porta bandeira sem seu pavilhão? O que seria do destaque central sem sua fantasia ou seu carro alegórico? O que seria dos instrumentistas da bateria sem o surdo, o tamborim ou o agogô?

\section{5 (RE)VIVENDO O CARNAVAL}

\subsubsection{A SOCIALIZAÇÃO DOS INTEGRANTES DA ESCOLA}

Uma das características da escola de samba é o fato de as famílias dos fundadores participarem ativamente do cotidiano da agremiação, ocupando, inclusive, cargos no conselho, na presidência e na diretoria da escola. Por conta disso, alguns integrantes afirmam que torcem pela escola "desde sempre", referindo-se ao fato de pertencerem a uma dessas famílias, frequentando a escola desde sua tenra infância. Durante as entrevistas, eu costumava perguntar aos integrantes da agremiação há quanto tempo eles frequentavam a escola.

Desde sempre. [...] a escola foi fundada na varanda da casa da minha avó [...] a gente cresceu envolvido nisso, [...] vendo que tudo estava acontecendo. [...] quando eu nasci, já existia a escola de samba [...] a gente não desfilava, mas a gente ia [...] pra assistir, a gente já ia pequena pro Sambão. 'Olha lá, seu pai está vindo, [...] acorda pra ver seu pai'. [...] na casa da minha avó era assim: eles faziam fantasias lá, porque minha tia era costureira [...] A dona Maria Coroa [fundadora da 
escola] é mãe do seu pai. [...] mesmo que indiretamente, toda a família por parte de pai já participou [da escola] (Entrevista diretora adjunta de harmonia)

Quando eu comecei era muito moleque ainda, ficava com meus irmãos e meus amigos. [...] a escola era só a bateria, só saíam os homens lá.[...] eu era moleque, tinha 11 anos. [...] carreguei o estandarte, depois meu pai fez um tamborzinho [...], eu saía tocando [...]. Aí já com 12, 13 anos comecei a tocar [na bateria da escola] [...] Com uns 19 anos eu ficava ajudando o [mestre de bateria] (Entrevista mestre de bateria)

De acordo com a diretora adjunta de carnaval: "ainda estão perpetuando essas famílias [de fundadores] dentro da agremiação, ainda não perdeu. Eu acho que o dia em que nossa escola perder isso, ela deixa de ser ela" (notas de campo). Todavia, nem todos os integrantes da escola são filhos das famílias fundadoras. Mesmo assim, várias dessas pessoas fazem parte do "mundo do samba" desde criança, assistindo aos desfiles, frequentando a quadra (da escola, ou até mesmo de outras agremiações da Grande Vitória), desfilando na ala das crianças, etc.

A minha história com o carnaval capixaba começa na minha infância, eu tenho um tio que é músico e ele era intérprete e compositor de samba numa escola em Vitória. [...] E o meu tio, como músico da escola e próximo do presidente da escola [...] lá em casa [...] chegava material [...] na casa da minha avó [...] a gente era criança e ficava empolgado com aquele monte de fantasia que vinha do Rio. [...] eu acredito que eu tinha uns 8 ou 9 anos. [...] eu fui crescendo, vendo aquela movimentação na minha casa e tal, aí quando comecei a ter uma certa idade, com 14 anos eu comecei a desfilar na escola de samba como passista, eu sambava. [...] eu também me lembro assim, que eu tirava minhas férias de trabalho e ficava no barracão da escola de samba trabalhando direto [...] (Entrevista destaque e estilista 2)

[...] a minha mãe levava a gente pra assistir [o desfile], meu pai não deixava a gente sair na ala das crianças [...]. Aí quando chegamos na adolescência nós saímos a primeira vez em uma ala, eu e minhas irmãs, na ala de índios, eu lembro até hoje, saindo de indiazinha [...]. Daí em diante eu nunca mais deixei de sair em escola de samba. [...]. Mas das três [irmãs] eu fui a única que fiquei mesmo, as outras duas já desistiram de carnaval [...]. Então da minha família mesmo, ela não é comprometida. [...] eu acabei casando com uma pessoa do samba e fiquei assim, completamente envolvida e apaixonada pelo carnaval (Entrevista diretora adjunta de carnaval)

Além disso, há integrantes da escola que entraram em contato com o carnaval somente na adolescência, ou até mesmo depois de adultos. Muitos deles conheceram o mundo do samba por estarem envolvidos em atividades correlatadas, que se sobrepõem às atividades que são realizadas por uma escola durante a produção de seu desfile. Conforme já mencionado, o carnavalesco participava de quadrilhas juninas, produzindo fantasias, e os escultores dos carros alegóricos da agremiação trabalhavam na "Festa do Boi", em Parintins/MA. Além desses profissionais, os coreógrafos da comissão de frente e alguns estilistas também se dedicavam a outras atividades antes de se envolverem mais diretamente com o carnaval.

Eu comecei em 2008 [...] No carnaval. [...] Mas com coreografia foi desde 1998. [...] Eu comecei com 7 anos [...], na banda marcial. E aí eu já comecei a ter contato. Como coreógrafo mesmo eu comecei uns anos depois e aí só por esse contato, por ver outros grupos coreográficos, a gente acaba tendo experiência e como a gente gosta, a gente vai se aperfeiçoando [...]. Eu iniciei como músico. E logo após, aí eu tive uns anos tocando na banda e sempre gostei da parte coreográfica. Quando surgiu essa oportunidade de coreografar, [...] eu entrei. E aí desfilei em São Paulo, numa escola de samba e no outro ano eu quis vir pra Vitória pra poder desfilar [...] aí tive a oportunidade pra formar uma ala [...]. E aí logo a gente foi também convidado pra participar da comissão de frente [...] Como integrante, dançando, e a gente era coreógrafo da ala. Então fazia duas funções (Entrevista coreógrafos da comissão de frente) 
Eu trabalhava como decorador de festas, trabalhei 15 anos da minha vida nesse segmento, dentro desse projeto de artes, fazendo eventos. Eu comecei a trabalhar com roupas, que é uma coisa que eu gosto. Então foi acontecendo muito natural, uma amiga minha queria uma roupa bordada, eu falei que sabia fazer, sem nunca ter feito, fiz e ficou legal e aí precisou de outras, outras e outras. E aí foi acontecendo, foi quando eu realmente fui desfilar, eu mesmo fiz a minha roupa e acabei sendo premiado [...] a partir daí as pessoas queriam usar uma roupa [...]. 'Ah, eu quero que você faça a minha'. [...] E aí aconteceu. [...] Isso foi em 2012, que foi meu primeiro ano na avenida (Entrevista destaque e estilista 1)

Já na bateria, a maioria dos instrumentistas são práticos, aprenderam a tocar seus instrumentos nas oficinas de bateria da própria escola, com o atual mestre de bateria, que também é um músico prático. Ou seja, esses instrumentistas nunca estudaram música de modo formal, não sabendo escrever nem ler uma partitura musical. Todavia, há alguns instrumentistas que, antes de começarem a tocar na bateria da agremiação, também se dedicavam a outras atividades correlatadas, sendo, por exemplo, alunos e professores de música clássica, da escola municipal de música de Vitória, e até mesmo instrumentistas de bandas militares.

Dessa forma, pude perceber que a história de vida da maioria das pessoas com os quais tive contato se confundia com a história do carnaval capixaba, da escola de samba e/ou de outras agremiações da Grande Vitória. Muitas vezes, as narrativas começavam na infância, período na qual esses indivíduos tiveram seus primeiros contatos com o carnaval, com a produção do desfile. No meu caso, minha história de vida não se confunde com a história do carnaval, mas minha história como pesquisadora-integrante-foliã começava e, porque não, também se mistura com o ciclo carnavalesco de 2014/2015 da escola.

\subsection{2 (VÉSPERA DE) CARNAVAL}

Se, por um lado, o carnaval é vivido desde a infância, desde a socialização primária de muitos dos integrantes da escola, ele também é revivido a cada novo ciclo carnavalesco. A medida que o desfile carnavalesco se aproximava, pude observar um "clima" crescente de "final de campeonato". Creio que esse clima começou a ficar latente quando a escola de samba foi convidada a participar de um dos ensaios gerais de uma escola de Vila Velha/ES (um dos municípios da Grande Vitoria).

Nesse dia, assim que a escola começou a se apresentar, já pude perceber tal "atmosfera", era nítido que os integrantes da escola se comportavam de modo diferente. A velha guarda estava presente, sambando e cantando os sambas-enredos. Até então não havia visto essa ala se apresentar. Os passistas, usualmente presentes nos ensaios, trajavam fantasias, e não o uniforme da escola. Também observei a presença ativa de vários harmonias, que abriam espaço para que a evolução das baianas, da velha guarda, dos passistas e dos casais de MS e PB acontecesse no meio da quadra, e não apenas em frente ao palco. Os instrumentistas da bateria também estavam muito animados, movimentando-se de um lado para o outro, enquanto cantavam os sambas da escola. Durante os ensaios, apesar da cobrança do mestre de bateria, o mesmo não costumava acontecer. Inclusive, a bateria e os intérpretes fizeram várias "paradinhas", para que o público participasse. Em resposta ao convite, todos os presentes cantaram. Durante os ensaios na quadra da própria escola, o "canto" era apontado pela diretoria de harmonia como uma preocupação. Diante disso, lembrei de uma máxima do futebol: "Treino é treino, jogo é jogo!". Esse clima de final de campeonato também foi relatado durante algumas entrevistas.

[...] eu tinha uma visão que o enredo não estava sendo funcional, não estava legal. Mas na [quadra da escola de Vila Velha/ES], no encontro com [essa escola de Vila Velha/ES] do último final de semana [...], o samba-enredo deles não empolgou. Mas quando a gente entrou [...] todo mundo cantou, todo mundo sambando, aquela festa toda. Parecia que a quadra era nossa. Então ficou uma coisa muito interessante. Eu falei: 'olha, o enredo tá pegando'. Principalmente naquela parte que fala: 'Itapemirim, encanta o Brasil, me faz reviver' [...]. Foi a questão assim, de mostrar que a escola está bem estruturada [...]. A rainha representou muito bem lá no espaço dela, a bateria, o intérprete [...] as passistas estavam ali dançando com a gente [...] a diretoria logo atrás, estava ali nos apoiando e rindo e tal. Então eu acho que foi um conjunto, [...] foi pra mostrar que a escola está feliz [...]. Está unida. E de fato agora no final a gente está bem unidos assim. [...] a gente está se divertindo e tal (Entrevista coreógrafos da comissão de frente) 
Todo mundo entra numa competição pra ganhar. Tem aquele papo: 'ah, eu vou pra me divertir'. Mas sempre quando entra lá, você quer ganhar. [...] Então a competição é isso, ela te leva a fortes emoções, porque você entra na competição com uma esperança [...]. E só em você conseguir superar tudo isso aí já é uma vitória (Entrevista mestre de bateria)

Todavia, apesar do crescente clima de final de campeonato, foi na concentração para o desfile e na avenida que a produção carnavalesca da escola atingiu seu clímax. Apesar da morte do presidente da agremiação, as pessoas sequer mencionavam a possibilidade de a escola deixar de desfilar, afinal, "colocar a escola na avenida" era uma "questão de honra". Durante o desfile carnavalesco, a diretoria da agremiação preparou uma surpresa, homenageando seu presidente, que também havia sido mestre de bateria e era um dos filhos da matriarca que fundou a escola. No último dos quatro carros alegóricos da escola havia um grande banner, com uma foto do presidente, sorrindo, e a seguinte frase: "uma vida, uma história, uma escola". Essa foi uma surpresa para o público e para muitos dos integrantes da própria agremiação, que, assim como eu, só souberam da homenagem na concentração, no dia do desfile. Atualmente, esse mesmo banner está na quadra da escola, fixado na parede que fica atrás do palco.

A "coruja aquática" do abre-alas foi outra surpresa (dessa vez apenas para o grande público e os jurados). De acordo com um dos diretores de carnaval: "Nossa escola é como a Portela no Rio, tem uma tradição no desfile que é a coruja. Se a coruja não vem, o povo até reclama. Já ficam esperando como vai vir a coruja esse ano" (Entrevista diretor adjunto de carnaval e diretor de comunicação). Tradicionalmente, a coruja do abre-alas é uma escultura de "corpo inteiro", branca ou marrom, representando essa ave de modo fidedigno. Todavia, em 2015, a diretoria de carnaval deu "carta branca" para que o carnavalesco fizesse uma releitura dessa escultura: "apesar dos mais tradicionais [...], eu falei assim: [...] é o que você achar melhor, você que é o carnavalesco. E se alguém falar, você fala: 'olha só, eu sou o carnavalesco. Se você não quer, me manda embora agora e aí você assume' [...]” (Entrevista diretor de carnaval).

Por estar em um carro que representava a nau de D. Pedro II que chegara à Itapemirim, a coruja era azul e tinha barbatanas, saudando o imperador. De acordo com o carnavalesco: "Fiz ela [a coruja] colorida! Ousar trazer a coruja não tradicional sempre foi a briga de todos os carnavalescos. Se não fizesse a coruja do jeito que eles [os integrantes mais antigos] queriam, cabeças rolavam. Mas eu meti as caras!" (Entrevista carnavalesco).

Segundo um dos diretores de carnaval, esse zelo com o primeiro e o último carro foi proposital:

[...] como é o primeiro carro que entra na avenida, sempre tem que ser um carro bem impactante [...] você tem que ter o primeiro carro bom, muito bom. 0 segundo pode ser mais ou menos e o terceiro carro pode ser pior. Aí o quarto carro melhora, o último carro tem que ser igual o abre-alas, tem que começar bem e terminar bem. O meio passa meio que batido. As pessoas vão lembrar sempre do começo e do final. A escola entrou bem e saiu bem (Entrevista diretor adjunto de carnaval e diretor de comunicação)

Fotografia 24 - Último carro alegórico

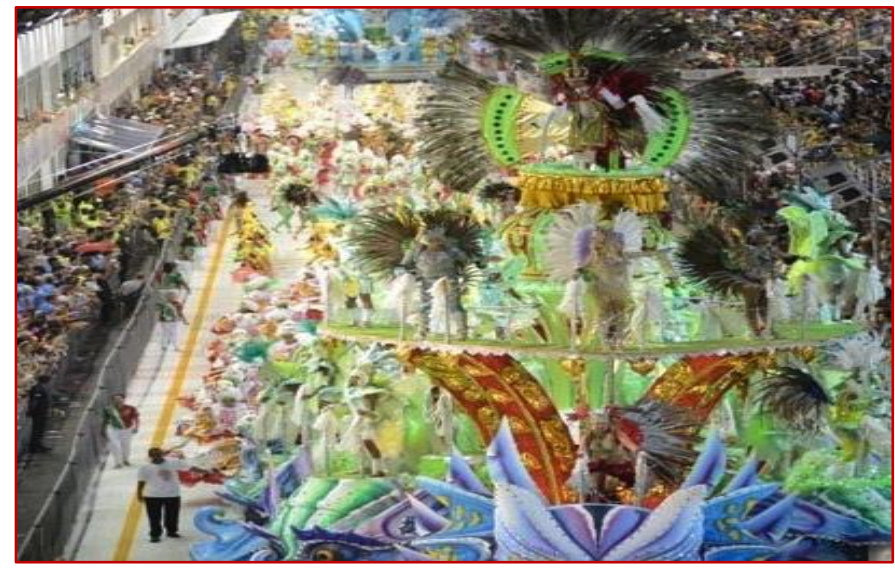


Carros alegóricos e fantasias não eram os únicos a representarem o enredo, uma vez que vários integrantes da agremiação relataram que, na avenida, assumiam um personagem, ficando compenetrados. Durante as entrevistas, perguntei o que eles sentiam durante o desfile carnavalesco:

[...] não tem como explicar [...]. Não dá pra sentir, porque era um personagem, é um espírito que baixa [...]. Você assume o personagem, você não sente, você é o personagem [...] são 40 minutos, no máximo. Você fica com a sua fantasia duas horas, porque você [...] vai pra concentração e tal. [...] É uma sensação de dever cumprido [...]. É a realização mesmo de interpretar um personagem, é um trabalho artístico. É um espetáculo que você se prepara para ser o personagem naquele espetáculo. Desde o folião de ala, ao passista, ao mestre-sala, porta-bandeira, a velha guarda, é a satisfação de ir lá representar um símbolo, representar um personagem, [...] mostrar com orgulho a sua escola passando na avenida. [...] São as raízes que se perpetuam [...] (Entrevista destaque e estilista 1)

A escola entrou, eu fico compenetrado. [...] se eu ver um problema lá atrás, aquilo já me aciona, ai eu tô lá, pra tentar resolver. O recuo da bateria também é um momento que me deixa muito apreensivo, sempre! Pra ver se vai dar tudo certo (Entrevista carnavalesco)

[...] eu sou muito tímido. Tanto que você não me vê sambando na quadra. [...] a avenida é o que eu mais gosto. Aí é onde eu realmente me realizo. [...] aí é outra história, [...] eu costumo dizer que eu gosto de ir pra avenida como personagem. Então eu gosto da produção de tudo, desde o sapato, a roupa, a maquiagem, o cílio postiço, a unha. Então assim, é uma outra pessoa, é um personagem que está na avenida. Então é diferente, aí eu não me sinto preso, não me sinto com vergonha. No dia da avenida não existe vergonha (Entrevista destaque e estilista 1)

Além disso, diante desta mesma pergunta, muitos componentes narravam que na concentração para o desfile sentiam um misto de ansiedade (perguntando-se se tudo daria certo) e de dever cumprido.

[...] Será que isso vai dar certo? Sempre aquela coisa meio desconfiada. Será que isso vai dar certo? Será que isso vai fluir? Será que essa roupa vai ficar boa? Será que essa fantasia vai dar um efeito legal na avenida? Será que não vai atrapalhar? Então a gente começa a pensar, daqui a pouco já está tudo montado e a gente nem acredita. Cara, eu nem acreditooo que a gente conseguiu fazer tudo isso, nossa! (Diretora adjunta de carnaval)

[...] eu me realizo mais com as alegorias. Eu acho que o grande publico espera. [...] porque mexe com o imaginário [...]. Eu adoro poder trazer os fatos históricos e tentar reproduzir [...] aquele tempo, pra quem tá vendo tentar se transportar praquele momento [...]. O meu sentimento, quando a escola entra na avenida, é de dever cumprido! (Entrevista carnavalesco)

[...] o amor pela escola, isso é fundamental, desfilar na nossa escola é uma realização, é algo inexplicável. [...] todos os anos eu venho recebendo [...] convites pra desfilar em outras agremiações e eu nunca aceitei. [...] elas não são a minha escola de coração. Eu quero brilhar na minha escola! [...] você é um patrocinador da escola, você está levando luxo [...] (Entrevista destaque e estilista 2)

Esse trecho da entrevista com o mestre de bateria explicita alguns dos significados atribuídos por muitos dos integrantes da escola ao carnaval, ao seu envolvimento direto com sua "escola do coração".

[...] reza a lenda que a gente vive várias vezes. Você vai e volta, vai e volta, vai e volta, até que você chega na última etapa da sua vida que é no samba, que é o momento da alegria. Aí, você chegou no paraíso, no samba, é alegria. [...] coisa bonita, um palco descontraído, uma outra história, uma outra vida. Não! Basta a gente estar nesse país com tanta miséria, tanto sofrimento (Entrevista mestre de bateria) 
Para esses foliões, carnaval é sinônimo de felicidade, sendo prazeroso estar envolvido com a produção do desfile. Todavia, esses indivíduos também são os responsáveis pelo "trabalho de fazer a festa" (BLASS, 2007), reconhecendo que "o trabalho é muito bom, é gostoso, mas dá muita dor de cabeça" (Entrevista diretora de harmonia). Durante o tempo que permaneci no campo, era comum ouvir os integrantes da escola dizendo: "Nunca mais vou desfilar!". Em geral, esse comentário era feito diante de uma dificuldade, soando como um protesto, ou logo após a realização de uma etapa importante (ao final do desfile carnavalesco, por exemplo), em tom de alívio. Além disso, a declaração também costumava vir seguida de risos, como uma ironia, uma vez que essas mesmas pessoas também admitiam: "a gente não vive sem carnaval!" (Entrevista destaque e estilista 1). Diante disso, passei a interpretar a expressão "Nunca mais vou desfilar" como uma pergunta retórica, seguida de muitas exclamações e interrogações.

Na verdade, todo ano quando acaba eu falo: 'Nunca mais eu vou botar o pé numa escola de samba'. Mas aí você não agüenta, é paixão, a gente gosta daqui, a gente não consegue ficar longe. Porque, na verdade, além do meu envolvimento com a escola, eu gosto do samba e gosto do carnaval. Então assim, eu freqüento muito as quadras, tenho amigos em várias escolas. Então assim, a gente tem uma ligação. Hoje basicamente o samba é minha válvula de escape (Entrevista diretor adjunto de carnaval e diretor de comunicação)

Do que eu mais gosto? De tudo! [...] é trabalhoso, mas você conseguir botar uma escola pra atravessar uma avenida, é fantástico. [...] mas dá muita dor de cabeça. Então todo ano a gente fala: 'Não quero saber mais disso'. Mas não tem jeito, aí no outro ano você está aqui de novo, aí começa tudo de novo, aí de novo [...] Todo ano você fala que não quer, mas sai... porque a gente não agüenta, a gente vê aquilo e: 'ah, vamos lá ajudar, vamos fazer alguma coisa'. E a gente sai [...] (Entrevista diretora adjunta de carnaval)

Eu faria tudo de novo. Todo ano eu falo que não, pra mim é a última vez. Todo mundo fala isso. Mas faz tudo de novo. [...] Porque é a cachaça, é um vício, é muito gostoso. Você, depois que você vive isso, se você fizer a primeira vez, é uma cachaça, não tem jeito. A coisa está no sangue (Entrevista mestre de bateria)

A medida que minha identidade no campo (de pesquisador para integrante da escola) se alterava, passei a fazer esse mesmo questionamento: "Nunca mais vou desfilar?!". Assim como acorre com os integrantes da escola, para mim, essa também é uma pergunta retórica. Aliás, confesso que em 2016 pretendemos (eu, meu marido e alguns familiares) sair em uma das alas da escola de samba. 


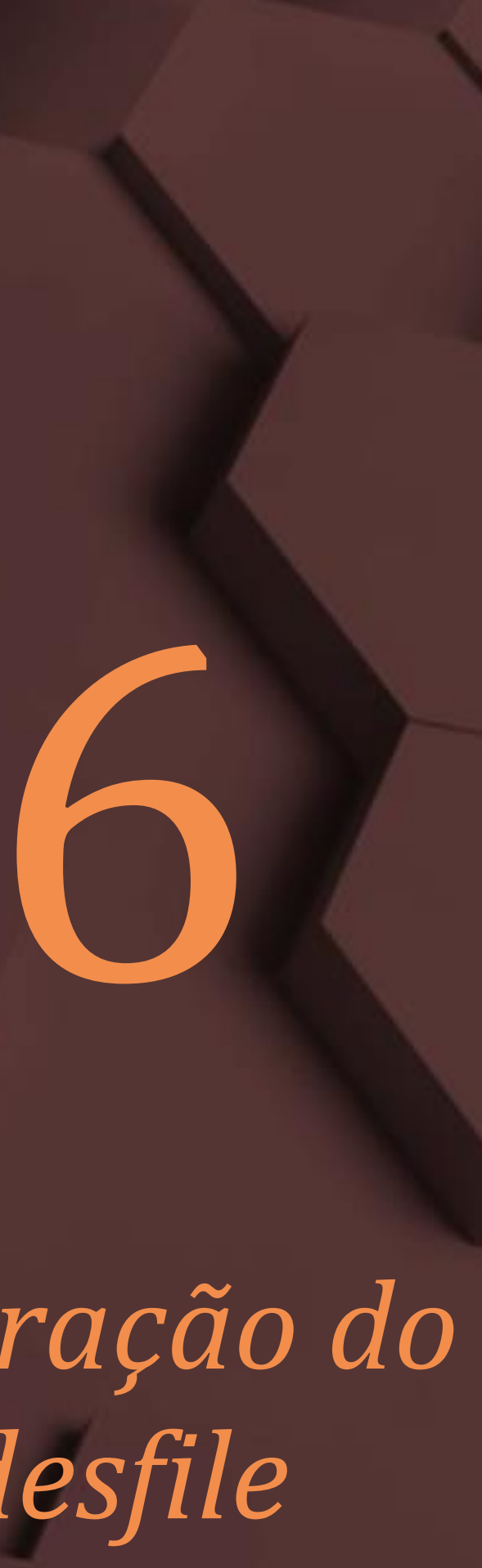

Apuração do desfile 
Neste capítulo, as práticas estratégicas empregadas na produção do desfile da escola são analisadas à luz dos referenciais teóricos apresentados nos capítulos anteriores.

\section{A ESCOLA DE SAMBA COMO FRUTO DE UM PROCESSO ORGANIZATIVO}

Entendo a escola de samba como uma organização, um fenômeno social que acontece, fruto de um processo organizativo (organizing) contínuo em que a "organização" é (re)construída no cotidiano, a partir de suas práticas (SCHATZKI, 2006; CZARNIAWSKA, 2013). Dessa forma, a palavra organização não é entendida de forma genérica, ou seja, como um substantivo ou um adjetivo, não estando associada a ideia de ordem, de algo organizado (em oposição a ideia de desordem). Pelo contrário, o conceito de organização está mais próximo de um verbo (BISPO; SANTOS, 2014), já que, por meio do organizing, autores como Weick (1979), Cooper (1986) e Czarniawska (2004, 2008, 2013) buscam transmitir a imagem de movimento, fluidez e (re)construção.

Além disso, conforme destaca Cooper (1986), o processo organizativo abarca "forças" complementares, mutuamente constituídas: a "organização" e a "desorganização", havendo na organização uma desordem intrínseca e fundamental. É justamente por isso que não faz sentido tratar uma organização simplesmente como uma estrutura inanimada, como coisas ordenadas, organizadas. $\mathrm{O}$ organizing pode ser melhor representado por um loop, um espiral, e não como uma cadeia linear de causas e efeitos; abarcando ambivalências e equívocos (disorganizing), uma tentativa de dar sentido à vida e ao mundo (extra)ordinário, um esforço, nunca completamente bem-sucedido, de lidar com a ambiguidade (CZARNIAWSKA, 2013). Conforme mencionado, a produção carnavalesca e o fazer estratégia da escola de samba foram marcados por contradições e ambiguidades. Por exemplo: ao mesmo tempo em que os integrantes da agremiação afirmavam não ser possível produzir um desfile sem dinheiro, esses mesmos sujeitos entendiam que dinheiro não era tudo, que com planejamento, criatividade, improviso e "bom gosto" era possível superar a escassez de recursos.

Dessa forma, pude perceber que elementos aparentemente opostos se complementaram, sendo esse um exemplo de que a "organização" e a "desorganização" são mutuamente constituídos. Uma das características das teorias da prática é justamente superar as várias dicotomias estabelecidas pelas teorias sociais modernas (mente Vs. corpo, pensar Vs. agir, sensorial Vs. racional, etc.), deslocando a ênfase para as relações entre os atores sociais e as práticas cotidianas. Assim, tais "contradições" enfatizam as conexões entre os elementos que compõem o desfile e não a dicotomia, a necessidade de se escolher entre um ou outro (entre o dinheiro e a criatividade e/ou entre o "bom gosto" e o uso de materiais mais simples e baratos, por exemplo), valorizando aspectos tácitos, sensíveis e estéticos.

Czarniawska (2008) ressalta, ainda, que as organizações modernas (enquanto obra de um processo de multi-site organizing) se desdobram em múltiplos contextos e ao mesmo tempo, abarcando diferentes temporalidades - acontecendo em um "tempo real" (SCHATZKI, 2006) -; uma vez que nem todas as interações exigem uma presença física. Conforme já destacado por Kaplan e Orlikowski (2013), determinadas práticas estratégicas relacionam-se com as interpretações múltiplas e divergentes de seus praticantes, o que engloba as percepções desses atores em relação ao passado, presente e futuro das práticas organizativas. Assim, o fazer estratégia não é o resultado de decisões tomadas por uma organização monolítica, mas sim produzido/realizado nas interpretações em curso e nas interações dos múltiplos atores organizacionais ao longo do tempo.

Diante disso, considero a escola de samba como uma organização multissituada, uma vez que seu fazer estratégia aconteceu (SCHATZZI, 2006) em múltiplos espaços/contextos organizacionais e de modo simultâneo (em um tempo real): Nos ateliês, no barracão pesado, na sede e na quadra da escola, nas ruas do bairro, no sambão do povo, no ginásio de esportes do Álvares Cabral, nos estabelecimentos comerciais do Rio de Janeiro e de São Paulo e, até mesmo, na casa e/ou no espaço de trabalho de seus integrantes e foliões. Além disso, a escola de samba, enquanto um fenômeno social que é fruto de um processo de (dis)organizing, abarca práticas difusas (dentre elas o fazer estratégia) que se desdobraram como um loop/espiral. Por exemplo: ao mesmo tempo que as fantasias eram confeccionadas, as alegorias eram produzidas, os ensaios das coreografias aconteciam e a comissão de carnaval se reunia com o carnavalesco. Além disso, a motivação dessas atividades estava no passado (honrar a memória do pavilhão e do presidente da escola), a atividade em si ocorria no presente (a produção do desfile carnavalesco de 2014/2015), enquanto que a ação tinha sua intenção/finalidade projetada para o futuro ("colocar a escola na avenida").

Confesso, inclusive, que, no inicio da pesquisa de campo, essa característica da escola de samba 
(enquanto uma organização multissituada que acontece em múltiplos contextos, em um tempo real) me deixou angustiada; uma vez que, como "marinheira de primeira viagem", eu estava ansiosa para acompanhar "tudo" o que acontecia, ou seja, o acontecimento do fazer estratégia e dos processos organizativos da agremiação.

\subsection{O FAZER ESTRATÉGIA DA ESCOLA DE SAMBA}

Ao refletir sobre o conteúdo de cada uma das categorias e subcategorias que emergiram da análise dos dados, ilustrando o fazer estratégia da escola, entendo que no ciclo carnavalesco de 2014/2015 a escola tinha como grande objetivo "representar positivamente sua comunidade" (CAVALCANTI, 1994). Afinal, "colocar a escola na avenida" era uma questão de honra, algo que não foi abalado nem mesmo com o falecimento do presidente da agremiação, há apenas dois dias do desfile. Pelo contrário, após essa grande perda, os integrantes da escola ganharam um motivo a mais para colocar a escola a avenida: honrar não apenas o pavilhão, mas também a memória de seu presidente. Para que isso fosse possível, era preciso "ir bem na avenida", mantendo-se no grupo especial, não correndo o risco de "cair" para o grupo B. Conforme destaca Araújo (2009), esse é o "carnaval de manutenção", um fenômeno especialmente presente quando se observa a conjuntura das pequenas escolas.

Questiono, assim, se o objetivo principal de uma escola de samba é simplesmente desfilar no carnaval (GOLDWASSER, 1975). Afinal, tal entendimento está centrado na performance da escola, apenas na "ponta do iceberg", e não no acontecimento do desfile carnavalesco e das agremiações enquanto um fenômeno social. Ressalto que, segundo Schatzki (2006), entender uma organização como um acontecimento não é simplesmente observar o acontecimento, a performance dessa organização.

Diante disso, destaco que as categorias Carnavalizando Um "Enredo Caça Níquel", Jogando As Regras Do Jogo, Produzindo Carros Alegóricos e (Re)Produzindo Fantasias ilustram o fazer estratégia da escola de samba enquanto uma prática que acontece, sendo realizada/performada por múltiplos atores sociais/organizacionais (SCHATZKI, 2006; KORNBERGER, CLEGG; 2011).

O fazer estratégia implica desenvolver uma imagem/projeção (normalmente grande) para o futuro, o que constrange e habilita o curso, o desdobramento de ações/atividades imediatas (KORNBERGER, CLEGG; 2011). Em relação à escola de samba, a projeção de futuro era "colocar a escola na avenida", honrando o pavilhão e o presidente da agremiação. Foi justamente essa intenção/finalidade que orientou o que fazia sentido para os integrantes da escola (inteligibilidade prática), constrangendo/habilitando o desdobramento das ações/atividades imediatas desses praticantes. Dessa forma, a própria descrição do fazer estratégia enfatiza que essa prática acontece em um tempo real, marcado pela co-ocorrência entre passado, presente e futuro (SCHATZKI, 2006).

Ressalto, ainda, que o fazer estratégia se desdobrou em torno de atividades centrais (de episódios da práxis, de atividades cotidianas realizadas pelas pessoas), que, por sua vez, estão ilustradas nas subcategorias de cada uma dessas categorias emergentes. Entendo que a última categoria, (Re)Vivendo O Carnaval, ilustra as teleoafetividades que organizaram, de forma marcante, todo o fazer estratégia da escola de samba. Afinal, conforme já destacado, o grande objetivo do carnaval de 2014/2015 foi honrar o pavilhão e a memória do presidente da escola. Esse era o desejo não apenas da diretoria ou do carnavalesco, mas de cada integrante e/ou folião que, assim como eu (enquanto pesquisadora-integrante-foliã), considera a escola sua "escola do coração".

Segundo Schatzki (2001), o que faz sentido para uma pessoa (inteligibilidade prática) depende de uma complexa combinação entre os fins que ela persegue e os afetos que ela sente ao se engajar em uma prática. Assim, ao afirmar que o grande objetivo da escola de samba era honrar o pavilhão e a memória do presidente, representando positivamente sua comunidade, questiono o argumento de Jarzabkowski, Balogun e Seidl (2007) e de Mantere (2005), segundo o qual a estratégia pode ser definida como aquelas atividades que têm consequência para os resultados, orientação, sobrevivência e vantagem competitiva da organização. Assim, considero que os objetivos de uma organização podem estar para além de seus resultados, orientação, sobrevivência ou vantagem competitiva - sendo esses exemplos de objetivos instrumentais, racionais -, abarcando, igualmente, emoções, humores, sentimentos e afetos dos indivíduos enquanto praticantes, enquanto atores sociais/organizacionais. De acordo com essa perspectiva, a afetividade também pode orientar o que as pessoas fazem, uma vez que os indivíduos socializados em torno de uma determinada prática incorporam versões das teleoafetividades que a organizam; o que também pode ser entendido enquanto um traço antropológico básico dos seres humanos (SCHATZKI, 2002). Dessa forma, objetivos instrumentais e 
racionais podem coexistir com humores, sentimentos e afetos dos indivíduos enquanto praticantes. Ou seja, o senso de propósito (telos) pode coexistir com os afetos, uma vez que esses elementos não são necessariamente contraditórios ou ambíguos, podendo se complementar.

Apesar de as emoções (afetos) serem consideradas como uma das dimensões da estratégica enquanto uma prática social (JARZABKOWSKI; SPEE, 2009), estudos sobre o papel da emoção no fazer estratégia ainda são raros. Além disso, mesmo quando a emoção é levada em conta, as pesquisas empíricas tendem a se concentrar nas emoções exibidas pela alta gerência (LIU; MAITLIS, 2014; JARZABKOWSKI; SPEE, 2009), negligenciado a dinâmica emocional/afetiva que constitui os processos organizativos e a vida social (RECKWITZ, 2012).

\subsection{A ORGANIZAÇÃO DO FAZER ESTRATÉGIA}

Segundo Schatzki (2002), a “organização" da vida social não é completa, perene e/ou autônoma. O social é fruto de um processo organizativo (organizing) contínuo, em que a organização é (re)construída no cotidiano, a partir de suas práticas (SCHATZKI, 2006; CZARNIAWSKA, 2013). Assim, entendo que a organização das práticas em torno dos elementos regras, entendimentos e teleoafetividades também é fluida e está em constante (re)construção, abarcando a "organização" e a "desorganização" enquanto "forças" complementares e mutuamente constituídas. Além disso, compreendo que as práticas estão interconectadas a regras, entendimentos e teleoafetividades de modo interdependente e mutuamente construído, não sendo possível reduzir os elementos que organizam as práticas a apenas uma de suas dimensões.

Diante disso, busco apresentar a organização do fazer estratégia da escola de samba de modo dinâmico e fluido, não separando os elementos regras, entendimentos e teleoafetividades; afinal, conforme destaca Cooper (1986), há na organização uma desordem intrínseca e fundamental. Sendo a prática social a unidade de análise da epistemologia de Schatzki, apresento a organização do fazer estratégia da escola por meio das categorias que emergiram da análise dos dados e representam as práticas estratégicas empregadas na produção do desfile.

A escolha por carnavalizar um "enredo caça níquel" foi uma das estratégias adotadas pela escola. Tal estratégia aconteceu por meio de algumas atividades centrais: homenagear cidades do Espírito Santo (Itapemirim, por exemplo) e evocar elementos da cultura local (a lenda da freira e do frade, conforme o sambaenredo de $2015^{30}$ ). A organização dessa estratégia e dessas atividades se deu em torno de teleoafetividades, entendimentos e regras (SCHATZKI, 2002, 2005). Honrar o pavilhão e a memória do presidente, representando positivamente a comunidade, foi justamente o que caracterizou o senso de propósito (fins e meios para se alcançar esse fim) dos integrantes da agremiação, a teleoafetividade que deu sentido a ação dos integrantes da escola. Ao incorporar microversões desses teleoafetos, os integrantes transformaram essa estrutura teleoafetiva em desejo, ansiando por colocar sua escola do coração na avenida, por "passar sem cair".

Havia, também, um entendimento compartilhado que organizava esse fazer estratégia: "Trazer luxo para a avenida". Pude perceber que um desfile era considerado "bom" e/ou "belo" - no sentido estético, e não ético, ou moral (SOARES; BISPO, 2015) - quando a escola "trazia luxo para avenida", impactando visualmente o público e, principalmente, os jurados. Dessa forma, entre os diretores, o carnavalesco e, até mesmo, os demais integrantes e foliões da agremiação, havia a percepção de que para a escola se sair "bem" era preciso ter carros alegóricos, fantasias (das alas e dos destaques) e coreografias bonitos, bem feitos, esteticamente bem apresentados. Era justamente essa percepção que fazia com que o carnaval fosse tido como uma festa cara. 0 que justificava a necessidade de um "enredo caça níquel".

É interessante notar, ainda, que a ação do carnavalesco, estilistas, costureiras, escultores, pintores, aderecistas e coreógrafos foi responsável pela produção do desfile. Todavia, não foi essa ação que impactou os jurados ou o público, motivando diretamente o prazer ou o desprezo desses sujeitos ao verem alegorias, fantasias e coreografias. Essas emoções foram causadas pela estética visual dos elementos materiais do desfile. A dimensão estética da estratégia também foi explorada por Kornberger e Clegg (2011) em um estudo empírico realizado na cidade de Sydney. Segundo os autores, o futuro da cidade australiana foi projetado por meio de uma mistura de técnicas de design, colagens, fotografias e esboços, criando um imaginário estético atraente que

\footnotetext{
30 Samba-enredo de 2005: Na colônia do Rio Novo / Avistou, se encantou... / Com uma linda história de amor / Condenados por se apaixonar / Em formato de pedra, eternizados no olhar.
} 
mobilizou a opinião pública. Assim como os cidadãos de Sydney, os jurados e o público do carnaval capixaba (enquanto praticantes do fazer estratégia) perceberam sensorialmente os aspectos visuais, julgando-os esteticamente (STRATI, 1999) por meio de um entendimento estético compartilhado (sensorial, empírico e não intelectual, refletido) que organiza as práticas.

Pude perceber, ainda, que "o carnaval é feito pros jurados, e não pro público". O que pode ser ilustrado pelo fato de o luxo que se leva para a avenida objetivar impactar principalmente os jurados. Inclusive, muitos dos detalhes de acabamento e do luxo das fantasias e dos carros alegóricos é imperceptível para o grande público. Diante disso, ressalto o efeito normativo das regras que organizaram a "carnavalização" do enredo da escola de samba, especificando quais ações e como essas ações deveriam ser executadas. Em um estudo de caso, Mantere (2005) já havia investigado como práticas estratégicas previsíveis permitem e constrangem (por meio da divulgação de informações, de métodos predefinidos de feedback e de metas explícitas) a ação dos atores organizacionais. A presença dos jurados enquanto avaliadores do desfile carnavalesco, assim como a existência de quesitos de julgamento previamente definidos, são exemplos de práticas previsíveis que influenciam a ação presente e futura dos praticantes.

Segundo Kaplan e Orlikowski (2013), determinadas práticas estratégicas relacionam-se com as interpretações múltiplas e divergentes de seus praticantes, o que engloba suas percepções em relação ao passado, presente e futuro das práticas organizativas. Assim, o fazer estratégia é realizado por meio das interações dos múltiplos atores organizacionais ao longo do tempo. Além disso, as regras que organizam as práticas estratégicas e regulam as atividades em torno das quais essa prática se desdobra evidenciam a relação recursiva entre o tempo passado, presente e futuro.

Além disso, ao prometer o patrocínio, o prefeito da cidade de Itapemirim, mesmo sendo um ator externo, que está fora da estrutura formal da organização, influenciou a estratégia (JARZABKOWSKI et al., 2007) da escola de samba. Autores como Tureta e Lima (2011) já haviam observado a existência de praticantes externos à organização estudada, destacando que, apesar de não deterem uma posição formal na hierarquia da organização, esses praticantes podem ser atores ativos no fazer estratégia. Atores externos a uma organização podem ser considerados estrategistas na medida em que contribuem para o direcionamento do fazer estratégia.

Jogar as regras do jogo foi outra estratégia adotada durante a produção do desfile carnavalesco, desdobrando-se em torno das seguintes atividades: analisar as notas dos quesitos de julgamento, contratar profissionais do carnaval e (re)ler o enredo. Para tal, os integrantes da agremiação precisaram, primeiramente, conhecer o jogo, compreender quais eram suas regras. Nesse caso, as regras eram os quesitos de julgamento. Por meio da atividade "analisar as notas dos quesitos" é perceptível que as regras dizem respeito a instruções, a critérios de decisão, guiando a ação dos indivíduos que (enquanto praticantes) as levam em consideração para julgar o que faz, ou não, sentido. O fato de a diretoria de carnaval analisar os quesitos para, posteriormente, (não) tomar decisões também evidencia que o efeito normativo das regras é praticado e não pré-determinado (SCHATZKI, 2002, 2005). Apesar de parecer óbvio que se deva seguir o regulamento do carnaval, nem sempre os atores se atentam para esse ponto.

A contratação de um carnavalesco "talentoso" também revela a estética da estratégia (KORNBERGER, CLEGG; 2011). Tal atividade somente foi exequível pelo fato de os diretores de carnaval e do próprio carnavalesco compartilharem o mesmo entendimento estético (STRATI, 1999) a respeito das práticas carnavalescas. Todavia, o know-how dos diretores refere-se à habilidade de os mesmos compreenderem a prática, enquanto que o know-how do carnavalesco também envolve sua habilidade de realizar determinadas atividades (por exemplo: confeccionar fantasias e produzir alegorias) que compõem essa prática. Além disso, carnavalesco e diretores também compartilhavam entendimentos intelectuais, refletidos; uma vez que esses praticantes traziam consigo a capacidade de lidar com a restrição financeira, de "produzir o carnaval mesmo sem dinheiro". Conforme mencionado, o carnavalesco atuava em quadrilhas juninas, que também possuem poucos recursos para produzir sua apresentação; o que ilustra que uma ação pode pertencer a mais de uma prática. Ou seja, as práticas podem se sobrepor, não havendo fronteiras rígidas separando-as, sendo as ações passadas, presentes e futuras recursivas e não independentes (SCHATZKI, 2003).

A contratação de profissionais do carnaval também aconteceu por meio da terceirização. Dessa forma, a produção de fantasias e carros foi suportada por uma ampla rede de atores - costureiras, ferreiros, escultores, pintores e aderecistas (todos eles parte de arranjos materiais) -, sem as quais os "atores centrais" (SCHATZKI, 2006) - o carnavalesco e os estilistas, por exemplo - não seriam capazes de produzir o carnaval. Para a EPS, a estratégia é construída por todos e nas atividades cotidianas de uma organização; ressaltando-se a interação entre o pensar e o agir, entre o planejamento e a execução das atividades estratégicas (WILSON; 
JARZABKOWSKI, 2004; WHITTINGTON; CAILLUET, 2008). Assim, atores de diferentes níveis hierárquicos são importantes no processo do fazer estratégia, apesar de não terem, necessariamente, um papel formal como estrategistas. Costureiras, ferreiros, escultores, pintores e aderecistas realizavam o fazer estratégia e davam forma à estratégia nas suas atividades cotidianas. Portanto, concordo com a afirmação de que a estratégia não é dada a priori e nem é exclusiva da alta direção; o que ressalta a interação entre o pensar e o agir, o planejamento e a execução das atividades estratégicas (WILSON; JARZABKOWSKI, 2004; WHITTINGTON; CAILLUET, 2008; JARZABKOWSKI; SPEE, 2009). Dessa forma, percebo a estratégia enquanto uma realização e não apenas como uma concepção intelectual.

Conforme mencionado, esses profissionais do carnaval foram "escolhidos a dedo" pela comissão de carnaval, sendo considerados experts devido ao know-how, à habilidade na arte de produzir carros e confeccionar fantasias (muitas vezes sem tantos recursos financeiros e em pouco tempo). Escultores, aderecistas e estilistas eram muito experientes e também trabalhavam na "Festa do Boi de Parintins" e para outras escolas de samba de São Paulo/SP e do Rio de /RJ. O que também ilustra a sobreposição das práticas e a co-ocorrência entre passado, presente e futuro.

A (re)leitura do enredo, por sua vez, tinha como propósito reduzir o custo de produção do desfile, mantendo a interpretação do enredo. Esse é um exemplo das estruturas teleoafetivas (senso de propósito) que organizaram a produção do desfile, uma combinação de fins e meios para se alcançar esse fim. Além disso, a grande preocupação em manter a interpretação do enredo ilustra o caráter afetivo da atividade de (re)leitura do enredo. Afinal, a agremiação é a escola do coração dos seus integrantes, que, movidos por uma complexa combinação de emoções, humores, sentimentos e afetos, dedicavam-se para "colocar a escola na avenida", "brigando para não cair, para ir bem na avenida". Como destaca Schatzki (2002), a afetividade também pode orientar o que as pessoas fazem, independente de seu senso de propósito. De modo complementar, o cuidado para que a história a ser contada na avenida não fosse alterada também ilustra uma regra formal, já que o regulamento do carnaval 2015 constrangia às agremiações a enviar o script do seu desfile à Liga das Escolas de Samba, evidenciando o efeito normativo das regras que organizam as práticas.

A comissão de carnaval, como a grande responsável pela (re)leitura do enredo, incorporou uma microversão própria dos elementos que organizavam a prática carnavalesca; estabelecendo critérios (muitas tácitos, não verbalizados) que orientaram o "corte" de alas e carros, assim como a substituição dos materiais que seriam usados na produção dessas alegorias e na confecção das fantasias dessas alas. $O$ fato de tais critérios não serem sequer verbalizados ilustra uma das características da perspectiva da prática, que tende a enfatizar o tácito e o informal, refletindo suas origens na sociologia da vida cotidiana (WHITTINGTON, 2006). É interessante destacar que o corte não afetou as alas das baianas, da velha guarda, dos passistas ou das crianças, mesmo não sendo esses quesitos formais. Segundo Cavalcanti (1994), esses são exemplos de elementos relevantes para o desfile e para a vida social de uma escola de samba que não são abarcados pelos quesitos de julgamento.

Diante disso, pude perceber que havia um entendimento compartilhado acerca da importância dessas alas (o que estava para além das regras formais). Assim, apesar de essas alas não serem julgadas diretamente e/ou explicitamente na apuração do desfile, fazia sentido mantê-las (JÚLIO, 2015). Ou melhor, os integrantes da escola nem sequer cogitavam a possibilidade de corta-las. Afinal, as baianas e a velha guarda representam a tradição da escola, os passistas passavam a imagem de que a agremiação tem "samba no pé", estando apta para desfilar no ciclo carnavalesco corrente, enquanto que as crianças simbolizam o futuro, a continuidade da escola.

Mais uma vez, percebe-se a co-ocorrência do tempo teológico. Segundo Schatzki (2006), as organizações são capazes de persistir ao longo do tempo devido à sua memória da prática, ou seja, devido a perpetuação dos elementos que organizam suas práticas. Assim, o fato de os elementos que organizam as práticas serem incorporados pelos praticantes durante sua socialização, como se possuíssem uma realidade "própria", confere certa "sensação" de estrutura (NICOLINI, 2013), fazendo com que os integrantes da escola sequer cogitem a possibilidade de cortar determinadas alas. Afinal, a apresentação das baianas, da velha guarda, dos passistas e das crianças e algo "tido como certo". A epistemologia de Schatzki nos ajuda a compreender que o que persiste é a memória da prática, a organização das práticas, e não a "estrutura" como um nível para além dos fenômenos sociais.

Além disso, o corte estratégico da ala da comunidade também foi usado pela diretoria para alavancar o "canto da escola", o quesito harmonia (que avalia justamente se os integrantes de cada uma das alas cantam o samba-enredo da agremiação). O que ilustra o papel das regras enquanto elementos que orientam a tomada 
de decisão. Todavia, a comunidade não deixou de desfilar, o que explicita o vínculo da escola com o espaço, com o contexto no qual se encontra sediada, sendo essa uma das características básicas das escolas de samba (CAVALCANTI, 1994; JÚLIO, 2015).

A escola de samba é parte inerente desse contexto, trazendo, inclusive, o bairro em seu nome. Da mesma forma, o bairro é parte intrínseca da escola. Ao acompanhar o cotidiano da escola e ao pesquisar sobre a agremiação, pude perceber que a história da escola se confunde com a do bairro, e vice-versa. Inclusive, muitos dos integrantes da escola de samba são "nascidos e criados" nessa localidade. O que faz com a história de vida desses sujeitos, de certo modo, também se confunda com a história da escola e do bairro. Conforme destaca Whittington (2007), o contexto permeia os praticantes e as práticas, o que faz com que o fazer estratégia esteja profundamente enraizado em seu contexto macrossocial (que engloba, por exemplo, a própria escola, o bairro, a Liga das Escolas de Samba, as prefeituras de Vitória e de Itapemirim e o governo do ES), ou seja, em sintonia com um conjunto mais amplo de conexões e relações.

Produzir carros alegóricos em 12 dias foi a alternativa encontrada para que, apesar da crise financeira, a escola pudesse "entrar na avenida", honrando seu pavilhão e a memória do então presidente. Tal estratégia somente foi exequível ao se desdobrar em torno de algumas atividades centrais: o (re)aproveitamento da estrutura dos carros alegóricos; a (re)utilização de esculturas; e a preocupação em relação a cores, detalhes e acabamento (afinal, "tamanho não é documento"). Mais uma vez, destaco que "Entrar na avenida", honrando seu pavilhão e a memória do presidente, era o senso de propósito que orientava o que fazia sentido para os integrantes da escola. Todavia, as teleoafetividades vão além desse senso de propósito, abarcando emoções, humores, sentimentos e afetos. O que pode ser evidenciado por meio da angústia e do medo que eu (enquanto pesquisadora-integrante-foliã) e os integrantes da escola sentimos ao testemunharmos, há menos de duas semanas para o desfile, que os carros alegóricos ainda estavam " no ferro".

Conforme destacado, o envio antecipado do script à liga constrangia as escolas. Todavia, ao incorporarem sua própria versão a cerca das regras que organizavam a produção carnavalesca, a comissão de carnaval da escola percebeu que era possível "driblar" o regulamento do carnaval - (re)aproveitando estruturas, (re)utilizando esculturas, produzindo carros/esculturas menores e transformando tripés em carros alegóricos. Afinal, a escola não havia especificado como seriam suas alegorias. As táticas de reutilização de estruturas e de esculturas (seja por meio da troca ou da releitura) é mais barata e rápida quando comparada à produção de novos carros alegóricos ou ao entalhamento de novas esculturas; o que também motivou (deu sentido) a ação dos integrantes da escola de samba. Diante disso, concordo com Whittington (2006), uma vez que a dependência dos praticantes em relação às práticas não é necessariamente passiva, já que a práxis também pode ser uma performance improvisada; tendo os praticantes a possibilidade de mudar as práxis nas quais estão envolvidos (WHITTINGTON, 2006). Conforme destaca Schatzki (2003), as práticas são "abertas" e melhor compreendidas através de seu dinamismo e movimento, o que inclui atividades irregulares, únicas e que estão em constante mudança.

Ao realizarem um estudo de caso no mercado da Vila Rubim (Vitória/ES), Silva, Carrieri e Souza (2011) observaram um duplo movimento nas atividades cotidianas do fazer estratégia: no sentido da manutenção e em prol da mudança das práticas. Segundo os autores, esse duplo movimento das práticas tem diferentes implicações: o reforço ou a transgressão da ordem estabelecida. Ao "driblar" o regulamento do carnaval, os integrantes da escola de samba também buscavam transgredir a ordem estabelecida. Conforme já destacado, 0 efeito normativo das regras é praticado e não pré-determinado. Apesar de destacar o efeito normativo das práticas estratégicas previsíveis - que permitem e a ação dos atores organizacionais -, Mantere (2005) também compreende a estratégia de modo dinâmico, como algo construído por meio de interpretações individuais, assim como por meio do improviso entre os estrategistas e executores. Também concordo com essa afirmação, rechaçando, porém, a distinção entre estrategistas e executores. Conforme mencionado, uma das características das teorias da prática é justamente superar as várias dicotomias estabelecidas pelas teorias sociais modernas (mente Vs. corpo e pensar Vs. agir, por exemplo). Dessa forma, compreendo costureiras, ferreiros, escultores, pintores, aderecistas, estilistas e carnavalesco "simplesmente" como praticantes do fazer estratégia, e não como estrategistas e/ou executores.

A (re)leitura das alegorias (descaracterizando esculturas, para que os jurados não percebam que esses elementos já foram usados em desfiles anteriores) exigiu um senso estético (STRATI, 1999) refinado dos responsáveis pela produção dos carros alegóricos, não sendo, justamente por isso, uma atividade muito comum entre as escolas de Vitória. Todavia, essa (re)leitura não requereu o uso de materiais caros ou novos, e sim a habilidade (know-how) de esses atores utilizarem materiais mais simples e baratos, ou, até mesmo, de 
desfiles anteriores, combinando cores e zelando pelo acabamento. Dessa forma, carnavalesco, soldadores, escultores, pintores e aderecistas compartilhavam um entendimento estético que organizava a prática de produção dos carros alegóricos; concordando, pelo menos tacitamente, em relação ao que fazer para conseguir produzir quatro alegorias e dois tripés em apenas 12 dias.

Mais uma vez, destaco que a produção das alegorias foi suportada por uma ampla rede de atores (todos eles parte de arranjos materiais) sem as quais os "atores centrais" (SCHATZKI, 2006) não seriam capazes de produzir o carnaval. Diante disso, concordo com o argumento de Kornberger e Clegg (2011). Segundo os autores, o fazer estratégia é uma realização, uma prática sociopolítica que visa mobilizar pessoas e legitimar decisões. A produção de carros e tripés em apenas 12 dias foi possível justamente porquê a comissão de carnaval foi hábil em mobilizar toda essa rede de atores que suportaram as atividades de (re)aproveitamento de estruturas, (re)utilização de esculturas e produção de carros/esculturas menores, executando e legitimando a decisão estratégica da direção da escola.

Conforme destacado, pude observar que, por meio de uma mistura de cores e de um acabamento cuidadoso, o carnavalesco buscava compensar o fato de a escola ter esculturas e carros alegóricos considerados pequenos; sendo essas táticas exemplos de atividades importantes para o fazer estratégia da escola de samba. Mais uma vez, ressalto o fato de o carnavalesco ter iniciado sua carreira artística nas quadrilhas de salão, tendo sido, desde sua juventude, socializado na arte de "produzir fantasias mesmo sem muito dinheiro", impactando visualmente o público e os jurados. Ao incorporar sua microversão dos elementos que organizam a produção artística (seja ela carnavalesca ou das quadrilhas), esse praticante desenvolveu um julgamento estético próprio, sendo hábil em combinar cores e em utilizar materiais simples e baratos com grande efeito visual. Conforme destacam alguns estudos (JARZABKOWSKI; BALOGUN e SEIDL, 2007; VAARA e WHITTINGTON, 2012), características sociais, políticas, retóricas e culturais influenciam o modo como cada praticante age enquanto portador do fazer estratégia. Afinal, é a práxis que faz o praticante, que molda sua capacidade de (re)acessar e (re)implementar as práticas (WHITTINGTON, 2006). Quando um indivíduo entra em uma comunidade de praticantes, ele aprende a tornar-se um membro desse grupo, absorvendo as particularidades dessa comunidade (WHITTINGTON, 2006), ou seja, as regras, os entendimentos e as teleoafetividades que organizam suas práticas.

A confecção das vestes que seriam utilizadas durante o carnaval de 2014/2015 aconteceu por meio da (re)produção das fantasias, sendo que atividades específicas guiaram essa (re)produção. A reprodução das fantasias das alas se desdobrou em torno da descentralização, sendo performada por diferentes estilistas, em ateliês que ficavam espalhados pela região metropolitana da Grande Vitória. Por outro lado, a produção das fantasias de destaque foi realizada por meio da tática de repaginação.

É interessante notar que tanto as fantasias das alas quanto as de destaque foram produzidas de modo não centralizado. Todavia, os fins e meios que levaram a essa descentralização são distintos. $O$ que deu sentido a descentralização da reprodução das fantasias das alas foi a percepção compartilhada pela comissão de carnaval de que trabalhar desse modo daria velocidade à confecção, sendo, além disso, mais econômico e prático. No caso dos destaques, o senso de propósito que orientou a ação foi o desejo de que especialistas confeccionassem as fantasias. Dessa forma, a descentralização foi uma consequência, não sendo uma atividade central em torno da qual a produção das fantasias de destaque se desdobrou.

Os meios que levaram a esses fins também eram distintos. Artefatos como protótipos e moldes deram suporte a reprodução das fantasias das alas. Além disso, cabia à escola definir, comprar e disponibilizar todo o material que seria utilizado. No caso das fantasias dos destaques, os croquis disponibilizados pelo carnavalesco foram os artefatos que suportaram o produzir fantasias. A escolha e a compra dos materiais ficava a critério dos estilistas, que eram livres para fazer a (re)leitura desses croquis. Todavia, conforme ocorreu no processo de produção dos carros alegóricos, a confecção das fantasias das alas e de destaques também foi performada por meio de uma mistura de cores, do aproveitamento de materiais já utilizados em outros carnavais e do cuidado em relação aos detalhes e ao acabamento. Nesse caso, os meios que levaram aos fins eram análogos.

Mais uma vez, pude observar que por meio de um julgamento estético próprio (STRATI, 1999) - da mistura de cores e do acabamento - o carnavalesco buscava compensar as restrições financeiras da agremiação, "levando luxo para a avenida". Conforme destacado, uma fantasia de ala podia ser considerada luxuosa pelo "simples" fato de misturar determinadas cores com "bom gosto". Dessa forma, se alguns detalhes de acabamento não eram percebidos pelo grande público; as cores eram impactantes, camuflando o uso de materiais mais simples, assim como a percepção de quem não estava "lá no meio", ou seja, diretamente envolvido na produção carnavalesca (o que inclui não apenas o público, mas também os jurados). 
Reafirmo que uma das coisas que mais chamou minha atenção foi o fato de as fantasias dos destaques não serem um dos quesitos de julgamento. Todavia, a importância dos destaques para a agremiação era notória, eles eram os responsáveis por "levar luxo para avenida", assim como por preencher eventuais espaços entre as alas e os carros alegóricos, ajudando no quesito evolução. Dessa forma, a organização das práticas está para além do efeito normativo direto das regras, que é praticado e não pré-determinado (SCHATZKI, 2002, 2005). Assim como ocorre com os passistas, a presença dos destaques passa a imagem de que a agremiação está apta para desfilar no ciclo carnavalesco corrente. Afinal, tanto o público quanto os jurados esperam que uma escola de samba "leve luxo para avenida", sendo a presença dos destaques "tida como certa". Mais uma vez, há a "sensação" de que o desfile carnavalesco possui uma "estrutura". Conforme destacado, a epistemologia de Schatzki nos ajuda a compreender que o que persiste é a memória da prática, a organização das práticas, e não a estrutura como um nível para além dos fenômenos sociais.

Ao longo da pesquisa de campo pude perceber que a história de vida da maioria das pessoas se confundia com a história do carnaval. Muitos indivíduos tiveram seus primeiros contatos (direta ou indiretamente) com a produção do desfile ainda na infância. Dessa forma, esses sujeitos aprenderam a participar das práticas carnavalescas durante sua socialização, adquirindo e incorporando microversões dos elementos que estruturavam essas práticas (SCHATZKI, 2002; RECKWITZ, 2002); o que inclui as teleoafetividades que organizaram, de forma marcante, todo o fazer estratégia da escola de samba a. Assim, para muitos dos integrantes da escola, honrar o pavilhão da escola significava honrar sua própria história, a história da sua família; o que ilustra o forte vínculo social e afetivo desses indivíduos como sua "escola do coração", abarcando emoções, humores, sentimentos e afetos. Conforme destacado, estudos sobre o papel da emoção no fazer estratégia ainda são raros e tendem a se concentrar nas emoções exibidas pela alta gerência (LIU; MAITLIS, 2014; JARZABKOWSKI; SPEE, 2009), negligenciado a dinâmica afetiva que constitui os processos organizativos e a vida social.

Se, por um lado, o carnaval é vivido desde a infância, ele também é revivido a cada novo ciclo carnavalesco, especialmente na véspera de carnaval (quando se é convidado a participar do ensaio de uma escola coirmã, por exemplo) e, é claro, durante o desfile. Mais uma vez, percebe-se que a motivação da ação estava no passado, uma vez que o desejo dos integrantes era honrar o pavilhão da escola. A atividade em si era performada no presente: por meio da homenagem ao presidente, da "coruja aquática" do abre-alas ou dos destaques que assumiam verdadeiros personagens na avenida. Já a intenção/finalidade da ação estava projetada para o futuro: manter-se no grupo especial, não "cair" para o grupo B. Segundo Kaplan e Orlikowski (2013), o fazer estratégia é realizado ao longo do tempo, por meio das interações de múltiplos praticantes, o que engloba suas percepções em relação ao passado, presente e futuro das práticas organizativas. Esses exemplos também ilustram o tempo real, a co-ocorrência entre passado, presente e futuro.

Assim, o acontecimento da escola de samba enquanto uma organização está para além da performance do seu desfile, sendo intensamente (re)vivido por seus integrantes enquanto praticantes do "fazer carnaval". Afinal, apesar do "trabalho de fazer a festa" (BLASS, 2007) e da ironia da declaração "nunca mais vou desfilar!", "não se vive sem carnaval", sendo prazeroso (ou até mesmo uma honra) estar diretamente envolvido com a produção do desfile da sua "escola do coração". 


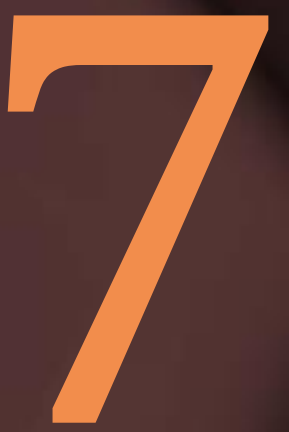

Pra tudo se acalmar na quarta feira 
“[...] Glória a quem trabalha o ano inteiro

Em mutirão [...]

[...] Gente empenhada em construir a ilusão

E que tem sonhos [...]

[...] Sonho de rei, de pirata e jardineira

Pra tudo se acabar na quarta-feira

Mas a quaresma lá no morro é colorida

Com fantasias já usadas na avenida

Que são cortinas, que são bandeiras

Razão pra vida tão real da quarta-feira

É por isso que eu canto" 31

Neste trabalho, o problema de pesquisa que direcionou minha investigação foi: como se organizam as práticas estratégicas da produção do desfile carnavalesco de uma escola de samba?. Para responder o problema de pesquisa, estabeleci o seguinte objetivo geral: analisar a organização das práticas estratégicas da produção do desfile que contribuíram para que a escola de samba "fosse para a avenida".

Para compreender esses fenômenos - as escolas de samba (como uma organização que vai além da performance do desfile), o desfile carnavalesco (como um conjunto organizado de práticas) e o fazer estratégia (enquanto uma prática social como outra qualquer) -, utilizei a epistemologia de Schatzki e a perspectiva da EPS como minha base teórica. A fim de alcançar o objetivo geral, realizei esta pesquisa por meio da triangulação da observação participante com entrevistas (exploratórias e semiestruturadas em profundidade), pesquisa documental e imagens/fotografias. Em relação à análise e interpretação dos dados, empreguei o procedimento de análise de conteúdo temático a posteriori.

Diante disso, ao finalizar este trabalho, analisando a organização das práticas estratégicas que contribuíram para "colocar" a escola "na avenida", concluo que o objetivo geral foi atingido.

Em relação aos resultados apresentados, reafirmo que as categorias Carnavalizando Um "Enredo Caça Níquel", Jogando As Regras Do Jogo, Produzindo Carros Alegóricos e (Re)Produzindo Fantasias ilustram o fazer estratégia da escola de samba enquanto uma prática que acontece. Destaco, ainda, que o fazer estratégia se desdobrou em torno de atividades centrais (ilustradas pelas subcategorias dessas categorias). $O$ que envolve múltiplos atores sociais, elementos humanos e não humanos, "fazeres" e "dizeres", regras, entendimentos e teleoafetos (SCHATZKI, 2002).

Por exemplo, a produção de fantasias e carros alegóricos foi suportada por uma ampla rede de atores - costureiras, ferreiros, escultores, pintores e aderecistas (todos eles parte de arranjos materiais) -, sem as quais os "atores centrais" - como o carnavalesco e os estilistas - não seriam capazes de produzir o carnaval. Para a perspectiva da EPS, atores de diferentes níveis hierárquicos são importantes no processo do fazer estratégia, apesar de não terem, necessariamente, um papel formal como estrategistas. Dessa forma, percebo o fazer estratégia enquanto uma realização e não apenas como uma concepção intelectual, o que não se restringe ao contexto do carnaval, podendo ser extrapolado para a indústria criativa, ou, até mesmo, para outras organizações.

Diante disso, a produção artística das indústrias criativas, ou o processo organizativo de uma organização qualquer, seria melhor representado por um loop, um espiral, e não por uma cadeia linear de causas e efeitos. Afinal, as organizações modernas são obra de um processo multissituado (CZARNIAWSKA, 2008), que acontece em múltiplos contextos (não apenas no barracão e nos ateliês, mas em vários países/continentes) e ao mesmo tempo (por exemplo: enquanto uma alegoria é produzida em um ateliê, um casal de MS e PB ensaia na quadra. Do mesmo modo, enquanto um chassi é montado na China, um consumidor brasileiro financia a compra de um carro).

\footnotetext{
31 Samba de Martinho da Vila, composto para o desfile carnavalesco de 1984 da Vila Isabel.
} Grifos meus 
Dessa forma, entendo que o fazer estratégia não ocorre no "vácuo", não sendo o resultado de decisões tomadas "aqui e agora" por estrategistas visionários. O fazer estratégia é uma realização de todos os envolvidos na concepção e na execução das atividades em torno das quais essa prática se desdobra, abarcando as percepções (múltiplas e divergentes) de seus praticantes em relação ao passado, presente e futuro. Assim, as ações passadas orientam a ação presente. Do mesmo modo, a intenção/finalidade projetada para o futuro, ou seja, o que se espera de um ato, também constrange e habilita a ação que está sendo performada no presente. Assim, o processo (des)organizativo e o fazer estratégia das organizações se desdobram em um "tempo real" (SCHATZKI, 2006). A motivação das atividades está no passado (honrar a memória do pavilhão escola ou garantir o emprego de montadores/vendedores), a atividade em si ocorre no presente (a produção do desfile carnavalesco ou a montagem/venda/financiamento de carros), enquanto que a ação tem sua intenção/finalidade projetada para o futuro ("colocar a escola na avenida" ou atingir a meta de produção/venda de carros).

No carnaval atual, na "briga" para não cair, espera-se que as escolas tenham fantasias e alegorias bonitas, bem feitas, esteticamente bem apresentadas. Afinal, um desfile só é considerado "bom" quando a escola "traz luxo para avenida", impactando visualmente o público e, principalmente, os jurados. Diante desse cenário, os integrantes da escola de samba (enquanto praticantes do fazer estratégia) souberam lidar com restrições financeiras e de tempo, tiveram um senso estético refinado, foram criativos, flexíveis, capazes de improvisar, souberam como utilizar materiais mais simples e baratos, ou, até mesmo, de desfiles anteriores, foram hábeis em combinar cores e zelosos com o acabamento de carros e fantasias.

Assim, o entendimento, o know-how (a habilidade de compreender a prática e de realizar/executar as atividades que compõem essa prática) de cada um desses integrantes em relação a como as práticas carnavalescas acontecem no carnaval capixaba foi fundamental para todo o fazer estratégia da escola, garantindo o vice-campeonato. Apenas profissionais especializados, que incorporaram, ao longo de sua socialização, microversões próprias dos elementos que organizam a prática carnavalesca, são hábeis em realizar as atividades que podem conduzir sua escola a uma apresentação que atenda aos requisitos (formais, informais e tácitos) de um bom desfile.

Diante disso, compreendo que as atividades da práxis também podem ser uma performance improvisada. Ao lançar mão de habilidades como senso estético, criatividade, flexibilidade, capacidade de improviso e de lidar com restrições financeiras e de tempo, os praticantes têm a possibilidade de mudar as atividades da práxis nas quais estão envolvidos. O que ilustra que o fazer estratégia é uma realização, indo além da simples tomada de decisão e/ou da implementação dessas decisões por meio de atividades rotinizadas e previamente definidas. O fazer estratégia abarca atividades difusas, irregulares, únicas e que estão em constante mudança.

A dimensão estética da estratégia, tão marcante no contexto da produção carnavalesca, também é um aspecto que pode ser extrapolado para a indústria criativa como um todo e, até mesmo, para outros contextos organizacionais. Por meio da estética (de aspectos visuais, por exemplo) é possível mobilizar pessoas. Afinal, o fazer estratégia implica desenvolver uma imagem/projeção (normalmente grande) para o futuro, o que constrange e habilita o desdobramento de ações imediatas. É possível ilustrar a estética da estratégia retomando o exemplo anterior: na indústria automobilística, as metas de produção de carros são constantemente expostas por meio de grandes quadros de gestão à vista, criando uma projeção para o futuro que constrange/habilita a ação dos montadores e dos demais empregados.

A estética é a faculdade sensorial humana de perceber, por meio dos sentidos, estímulos (sejam eles visuais, auditivos, olfativos, táteis ou gustativos). Todavia, a estética está para além da percepção física dos sentidos, sendo a expressão de habilidades (muitas vezes tácitas) socialmente construídas, uma forma de comunicação diferente da escrita ou da fala. Assim, praticantes de diferentes práticas possuem diferentes percepções sensoriais, diferentes julgamentos estéticos. Um integrante de uma escola de samba é capaz de julgar se uma alegoria/fantasia está "bela", "luxuosa" e/ou bem feita. Ao visualizar um quadro de gestão à vista, um montador tem a habilidade de interpretar, rapidamente, se a produção de carros está "indo bem ou mal".

O efeito normativo das regras que organizam a produção carnavalesca também foi observado, de modo transversal, em todas as categorias que emergiram da análise dos dados, permeando todo o fazer estratégia da escola de samba. Nesse caso, as regras eram os quesitos de julgamento e "Jogar as regras do jogo" foi uma das estratégias adotadas durante a produção do desfile carnavalesco. As regras dizem respeito a instruções, a critérios de decisão, guiando a ação dos indivíduos que (enquanto praticantes) as levam em 
consideração para julgar o que faz, ou não, sentido. As regras especificam quais ações e como essas ações devem ser executadas, organizando as práticas e regulando as atividades. Apesar de as regras habilitarem/constrangerem a ação presente (o que também evidenciam a relação recursiva entre o tempo

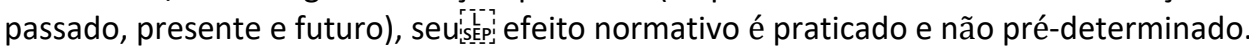

Por exemplo, um ator organizacional pode incorporar versões das regras que organizam as práticas, o fazer estratégia da organização na qual está imbricado, considerando que faz sentido, que convém seguir a legislação que regulamenta sua atividade (a produção/venda de carros, por exemplo). Para um indivíduo que não foi socializado nessa prática, seguir a legislação pode não fazer nenhum sentido. Nesse caso, as regras que organizam essa atividade não teriam nenhum potencial normativo. Além disso, esse mesmo ator organizacional poderia optar por "driblar" a legislação que regulamenta sua atividade. O que, mais uma vez, evidencia que o efeito normativo das regras é praticado e não pré-determinado.

A última categoria apresentada - (Re)Vivendo O Carnaval - ilustra as teleoafetividades que organizaram, de forma marcante, todo o fazer estratégia da escola de samba. O grande objetivo do carnaval de 2014/2015 foi honrar o pavilhão e a memória do presidente da escola. Esse era o desejo não apenas da diretoria ou do carnavalesco, mas de cada integrante e/ou folião que considerava a agremiação sua "escola do coração".

Diante disso, considero que os objetivos de uma organização estão para além de seus resultados, orientação, sobrevivência ou vantagem competitiva; podendo coexistir com os afetos dos indivíduos enquanto praticantes. Afinal, entender os objetivos organizacionais de modo estritamente performático é enxergar apenas a "ponta do iceberg" e não o acontecimento das organizações enquanto um fenômeno social. Os objetivos (senso de propósito ou finalidade) de uma organização, ao serem incorporados pelos atores sociais durante sua socialização, transformam-se em desejos, abarcando emoções, humores, sentimentos e afetos dos indivíduos enquanto praticantes do fazer estratégia. A afetividade (afetos, emoções, humores e sentimentos) também pode orientar o que as pessoas fazem (o que motiva o trabalho de um montador, por exemplo, pode não ser apenas seu salário mensal, mas também o desejo de ser reconhecido pelo chefe como o "melhor" da linha de produção); o que pode ser entendido enquanto um traço antropológico básico dos seres humanos (SCHATZKI, 2002). Apesar de as emoções (afetos) serem consideradas como uma das dimensões da estratégica enquanto uma prática social, estudos sobre o papel da emoção no fazer estratégia ainda são escassos. Além disso, mesmo quando a emoção é levada em conta, as pesquisas empíricas tendem a se concentrar nas emoções exibidas pelos gestores (top managers) (LIU; MAITLIS, 2014; JARZABKOWSKI; SPEE, 2009), negligenciado a dinâmica emocional/afetiva que constitui os processos organizativos e a vida social.

Compreendo, ainda, que há na "organização" uma desordem inerente e fundamental. Por isso, vejo as organizações como fruto de um processo (des)organizativo e não como uma estrutura formal e/ou física pronta e acabada. As organizações são, ainda, marcadas por contradições e ambiguidades, fenômenos sociais dinâmicos que abarcam elementos aparentemente opostos, mas que se complementaram (as áreas de Finanças e Recursos Humanos, ou a de Marketing e Produção, por exemplo). Tais contradições enfatizam as conexões entre os elementos que compõem o processo (des)organizativo e não a dicotomia, a necessidade de se escolher entre um ou outro (entre o dinheiro e a criatividade, por exemplo). Afinal, a organização e a desorganização são mutuamente constituídas. Uma das características das teorias da prática é justamente superar as várias dicotomias estabelecidas pelas teorias sociais modernas, deslocando a ênfase para as relações entre os atores sociais e os elementos que compõem as práticas cotidianas.

Este trabalho contribui para o campo dos Estudos Organizacionais e para a literatura de EPS ao discutir como o fazer estratégia é realizado em uma organização tipicamente brasileira, as escolas de samba. Apesar de essas agremiações serem objeto de estudo da sociologia e da antropologia desde a década de 1960 e do significativo impacto econômico e social para o país (geração de trabalho e renda, apelo turístico e cultural), o carnaval tem sido pouco explorado no campo dos Estudos Organizacionais. De modo mais específico, este trabalho explora como o fazer estratégia está organizado, buscando compreender o nexo entre os elementos regras, entendimentos e teleoafetividades, que organizam essa prática social, e os arranjos materiais, que suportam a produção do desfile carnavalesco. Conforme destacado, apesar de Schatzki ser um dos principais autores contemporâneos do campo das teorias da prática, seus trabalhos ainda carecem de aplicação empírica direta.

Algumas limitações também acompanharam este trabalho. Devido ao falecimento do presidente da agremiação, não foi possível entrevista-lo formalmente; sem dúvida, esse seria um ator relevante para a compreensão do fazer estratégia da escola. Além disso, por ser a escola de samba uma organização 
multissituada, não foi possível acompanhar o desdobramento de todas as atividades da produção carnavalesca. Inclusive, várias dessas atividades aconteceram ao mesmo tempo e em locais diferentes. Também destaco o tempo de coleta de dados como outra limitação. Ao ingressar no campo a partir de outubro, não pude acompanhar a concepção do carnaval (a escolha do enredo e do samba-enredo, por exemplo). Justamente por isso, tive que delimitar esta pesquisa à análise da produção do desfile carnavalesco.

Estudos futuros poderiam tratar assuntos que tangenciaram este trabalho, mas que não foram abordados com foco analítico. Outras pesquisas poderiam discutir como a dinâmica emocional influencia o fazer estratégia; questionando, inclusive, se emoções, humores, sentimentos e afetos são "apenas" elementos que organizam as práticas, ou exemplos de práticas organizativas. A estética da estratégia e da vida organizacional também poderia ser discutida, Outra sugestão é o estudo da estética da estratégia (especialmente quando o objeto estudado relaciona-se com a indústria criativa). Seria interessante investigar como é possível mobilizar pessoas por meio de aspectos sensoriais (visuais, por exemplo). Afinal, o fazer estratégia implica desenvolver uma grande imagem/projeção para o futuro, o que orienta o desdobramento das ações imediatas. Por fim, o fazer estratégia de outras manifestações culturais e/ou organizações tipicamente brasileiras também poderia ser pesquisado (a exemplo da "Festa do Boi" de Parintins e das Quadrilhas Juninas)

\section{REFERÊNCIAS}

[1] ARAÚJO, E. Vida e morte das pequenas escolas de samba: uma aproximação histórica e antropológica das escolas dos grupos de acesso "C", " $D$ " e "E" do Rio de Janeiro. Textos escolhidos de cultura e arte populares, v. 6, n. 1, 2009.

[2] BAUER, M.; GASKELL, G; ALLUM, N. Qualidade, quantidade e interesses do conhecimento - evitando confusões. In: BAUER, M. W.; GASKELL, G. Pesquisa qualitativa com texto, imagem e som. Rio de Janeiro: Vozes, 2002

[3] BAUNSGAARD, V. V.; CLEGG, S. 'Walls or Boxes': The Effects of Professional Identity, Power and Rationality on Strategies for Cross-Functional Integration. Organization Studies, 2013.

[4] BISPO, M. S.; SANTOS, I. S. A. A organização do cotidiano na orla de João Pessoa: um olhar etnometodológico da prática do voluntariado. Farol - Revista de Estudos Organizacionais e Sociedade, v. 1, n. 2, p. 379-416, 2014.

[5] BLASS, L. M. S. Desfile na avenida, trabalho na escola de samba: a dupla face do carnaval. São Paulo: Annablume, 2007.

[6] BOAS, F. Antropologia cultural. Rio de Janeiro: Jorge Zahar, 2004.

[7] BRESLER, R. A roupa surrada e o pai: etnografia em uma marcenaria. In: MOTTA, F. C. P.; CALDAS, M. P. Cultura organizacional e cultura brasileira. São Paulo: Atlas, 2009. p. 111- 126.

[8] BUCHANAN, D. A. The Role of Photography in Organization Research. Journal of Management Inquiry. 10(2), 151-164, 2001

[9] CARRIERI, A. P. et al. Estratégias e táticas empreendidas nas organizações familiares do Mercadão de Madureira (Rio de Janeiro). Revista de Administração Mackenzie, v. 13, n. 2, 2011.

[10] CARTER, C.; CLEGG, S. R.; KORNBERGER, M. Um livro bom, pequeno e acessível sobre estratégia. Bookman, 2010.

[11] CAVALCANTI, M. L. V. C. Carnaval carioca: dos bastidores ao desfile. Rio de Janeiro: Minc/Funarte, 1994.

[12] CAVEDON, N. R. Antropologia para administradores. Porto Alegre: UFRGS, 2003.

[13] CHIA, R.; MACKAY, B. Post-processual challenges for the emerging strategy-as-practice perspective: Discovering strategy in the logic of practice. Human relations, v. 60, n. 1, p. 217-242, 2007

[14] CLIFFORD, J. A Experiência Etnográfica: Antropologia e Literatura no Século XX. 3. ed. Rio de Janeiro: Editora UFRJ, 2008.

[15] COOPER, R. Organization/Disorganization. Social Science Information, 25, 2, p. 299-335, 1986. 
[16] CRESWELL, J. W. Projeto de pesquisa: método qualitativo, quantitativo e misto. Porto Alegre: Artmed, 2007.

[17] _. Qualitative inquiry and research design: choosing among five approaches. Sage, 2012.

[18] CUNLIFFE, A. L. On Becoming a Critically Reflexive Practitioner. Journal of Management Education, $v$. 28, n. 4, p. 407-426, 2004.

[19] CZARNIAWSKA, B. On time, space, and action nets. Organization, v. 11, n. 6, p. 773-791, 2004.

[20] _. Organizing: how to study it and how to write about it. Qualitative Research in Organizations and Management: An International Journal, 3(1), 4-20, 2008.

[21] . Organizations as obstacles to organizing. In: ROBICHAUD, D.; COOREN, F. (Ed.). Organization and organizing: Materiality, agency and discourse. Routledge, 2013.

[22] DALLA CHIESA, C.; FANTINEL, L. "Quando eu vi, eu tinha feito uma etnografia": notas sobre como não fazer uma "etnografia acidental". VIII ENEO. Anais... Gramado, 2014.

[23] DENIS, J. L.; LANGLEY, A.; ROULEAU, L. Strategizing in pluralistic contexts: Rethinking theoretical frames. Human Relations, v. 60, n. 1, p. 179-215, 2007.

[24] DE OLIVEIRA, J. S.; CAVEDON, N. R. Micropolíticas das práticas cotidianas: etnografando uma organização circense. Revista de Administração de Empresas, v. 53, n. 2, p. 156-168, 2013

[25] ELTON, E. Logradouros Antigos De Vitória. Vitória: EDUFES, 1999.

[26] FELDMAN M. Resources in Emerging Structures and Processes of Change, Organization Science, 15, 3: 295-309, 2004.

[27] FELDMAN, M. S.; ORLIKOWSKI, W. J. Theorizing practice and practicing theory. Organization Science, v. 22, n. 5, p. 1240-1253, 2011.

[28] FLICK, U. Uma introdução à pesquisa qualitativa. Porto Alegre: Bookman, 2004.

[29] FRANCO, M. L. P. B. Análise de Conteúdo. 4. ed. Brasília: Liber Livro, 2012.

[30] GHERARDI, S.; STRATI, A. Administração e aprendizagem na prática. 1. ed. Rio de Janeiro: Elsevier, 2014.

[31] GODOI, C. K.; BANDEIRA-DE-MELO, R.; SILVA, A. B. da (Orgs.). Pesquisa Qualitativa em Estudos Organizacionais: paradigmas, estratégias e métodos. São Paulo: Saraiva, 2006.

[32] GODOY, A. S. Introdução à pesquisa qualitativa e suas possibilidades. Revista de Administração de Empresas, v. 35, n. 2, p. 57-63, mar./abr. 1995.

[33] GOLDWASSER, M. J. O palácio do samba: estudo antropológico da escola de samba Estação Primeira de Mangueira. Rio de Janeiro: Zahar Editores, 1975.

[34] GOLSORKHI, D. et al. Introduction: What is Strategy as Practice?. In: Strategy as Practice. Cambridge: Cambridge University Press. p. 1-22, 2010.

Cambridge Handbook of

[35] HOLLANDA, B. B. B. de. País do Carnaval! País do Carnaval? (Uma apresentação alentada ao dossiê: Carnavais \& organizações). Organizações \& Sociedade, v. 20, n. 64, p. 99-109, 2013.

[36] JARZABKOWSKI, P.; BALOGUN, J.; SEIDL, D. Strategizing: the challenges of a practice perspective. Human Relations, v. 60, n. 1, p. 5-27, 2007.

[37] JARZABKOWSKI, P.; SEIDL, D. The role of meetings in the social practice of strategy. Organization Studies, v. 29, n. 11, p. 1391-1426, 2008.

[38] JARZABKOWSKI, P.; SPEE, A.P. Strategy - as - practice: A review and future directions for the field. International Journal of Management Reviews, v. 11, n. 1, p. 69-95, 2009.

[39] JARZABKOWSKI, P.; SPEE, A. P.; SMETS, M. Material artifacts: practices for doing strategy with 'stuff'. European management journal, v. 31, n. 1, p. 41-54, 2013.

[40] JÚLIO, A. C.; TURETA, C. Estratégia como prática na produção do desfile de uma escola de samba. VII Encontro de Estudos em Estratégia. Anais... Brasília, 2015. 
[41] JÚLIO, A. C. Produzindo o Desfile Carnavalesco de uma Escola de Samba: Contribuições de Theodore Schatzki. XXXIX ENANPAD. Anais... Belo Horizonte, 2015.

[42] KAPLAN, S.; ORLIKOWSKI, W. J. Temporal work in strategy making. Organization science, v. 24, n. 4, p. 965-995, 2013.

[43] KORNBERGER, M.; CLEGG, S. Strategy as performative practice The case of Sydney 2030. Strategic Organization, v. 9, n. 2, p. 136-162, 2011.

[44] KRIPPENDORFF, K. (2004). Content analysis: An introduction to its methodology. London: Sage.

[45] LIU, F.; MAITLIS, S. Emotional dynamics and strategizing processes: a study of strategic conversations in top team meetings. Journal of Management Studies, v. 51, n. 2, p. 202-234, 2014.

[46] MALINOWSKI, Bronislaw. Argonautas do Pacífico Ocidental. São Paulo: Abril Cultural, 1978.

[47] MANTERE. S. Strategic Practices as Enablers and Disablers of Championing Activity, Strategic Organization, v. 3, n. 2, p. $157-184,2005$.

[48] MINTZBERG. H. Structure in 5'S: a synthesis of the research on organization design. Management Science. v. 26, n. 3, p. 322-341, 1980.

[49] MINTZBERG, H.; AHLSTRAND, B.; LAMPEL, J. Safári da estratégia. Bookman, 2009.

[50] MINTZBERG, H.; WATERS, J. A. Of strategies, deliberate and emergent. Strategic management journal, v. 6, n. 3, p. 257-272, 1985.

[51] MONTEIRO, L. Carnaval capixaba: Histórias, honras e Glórias. Serra: Ed. do Autor, 2010

[52] MONTERO, M. El sentido y la medida: reflexiones sobre el método. Comportamiento, v. 4. n. 1, p. 6581, 1995.

[53] NICOLINI, D. Practice Theory, Work, \& Organization: an introduction. Oxford: Oxford University Press, 2013

[54] OLIVEIRA, J. S. A política emocional nas práticas de organização do circo contemporâneo: uma etnografia multissituada no contexto Brasil-Canadá. 296 f. Tese (Doutorado em Administração) Universidade Federal do Rio Grande do Sul, Porto Alegre, 2014.

[55] OLIVEIRA, J. S.; CAVEDON, N. R. Micropolíticas das práticas cotidianas: etnografando uma organização circense. Revista de Administração de Empresas (Impresso), v. 53, n. 2, p. 156-168, mar/abr 2013.

[56] PECl, A. Além da dicotomia objetividade - subjetividade. In: VIEIRA, M. M. F.; ZOUAIN, D. M. (Orgs.). Pesquisa Qualitativa em Administração. Rio de Janeiro: Editora FGV, 2006.

[57] RECKWITZ, A. Toward a Theory of Social Practices: A development in culturalist theorizing. European journal of social theory, v. 5, n. 2, p. 243-263, 2002.

[58] Affective spaces: a praxeological outlook. Rethinking History: The Journal of Theory and Practice, v. 16, n. 2, p. 241-258, 2013.

[59] SANTOS, L. L. S. O trem não pode parar: reformando uma oficina de locomotivas. 311f. Tese (Doutorado em Administração) - Escola de Administração de Empresas de São Paulo da Fundação Getúlio Vargas, São Paulo, 2014.

[60] SANTOS, L. L. S. ; SILVEIRA, R.. Por uma Epistemologia das Práticas Organizacionais: A contribuição de Theodore Schatzki. Organizações \& Sociedade, v. 22, n. 72, 2015.

[61] SCHATZKI, T. R. The site of the social: a philosophical account of the constitution of social life and change. Pennsylvania: Pennsylvania State University, 2002.

[62] __. A New Societist Social Ontology. Philosophy of the Social Sciences. 33(2), 2003.

[63] _. The Sites of Organizations. Organization Studies. 26(3), 2005

[64] _. On organizations as they happen. Organization Studies, 27(12), 1863- 1873, 2006.

[65] _. The Timespace of Human Activity: On Performance, Society, and History as Indeterminate Teleological Events. Lanham, Maryland: Lexington Books, 2010. 
[66]

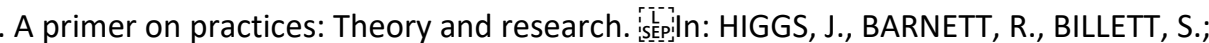
HUTCHINGS, M.; TREDE, F. Practice-based education: perspectives and strategies. Rotterdam, The Netherlands: Sense Publishers, 2012.

[67] SCHATZKI, T.; KNORR-CETINA, K.; VON SAVIGNY, E. The practice turn in contemporary theory. London: Routledge, 2001.

[68] SCOTT, W. R. Field Methods in the Study or Organizations. In: J. G. March (Ed.). Handbook of Organizations. Chicago: Rand McNally \& Company, 1972.

[69] SEIDL, D.; WHITTINGTON, R. Enlarging the Strategy-as-Practice Research Agenda: Towards Taller and Flatter Ontologies. Organization Studies, p. 1-15, 2014.

[70] SILVA, A. R. L.; CARRIERI, A. P.; SOUZA, E. M. Social practices and strategizing: a study of produce merchants in the Vila Rubim market. Brazilian Administration Review, v. 8, n. 1, p. 86-106, 2011.

[71] SOARES, L. C.; BISPO, M. S. O processo de aprendizagem do cozinhar na formação do gosto em dois restaurantes de comida regional em João Pessoa-PB à luz das práticas sociais e da estética organizacional. XXXIX ENANPAD. Anais... Belo Horizonte, 2015.

[72] SOU ES (2015). Disponível em: http://www.soues.com.br. Acesso em: 15 jul. 2015.

[73] STAKE, R. E. Case studies. In: DENZIN, N. K.; LINCOLN, Y. S. Handbook of qualitative research. Thousand Oaks, London, New Delli: Sage, 1994.

[74] STRATI, A. Organization and aesthetics. Sage, 1999.

[75] STRATI, A. Estética no estudo da vida organizacional. In: Administração e aprendizagem na prática. 1. ed. Rio de Janeiro: Elsevier, 2014.

[76] TURETA, C. Práticas Organizativas em Escolas de Samba: o Setor de Harmonia na Produção do Desfile do Vai-Vai. 325 f. Tese (Doutorado em Administração) - Escola de Administração de Empresas de São Paulo da Fundação Getúlio Vargas, São Paulo, 2011.

[77] TURETA, C.; ALCADIPANI, R.. Entre o Observador e o Integrante da Escola de Samba: os Não-Humanos e as Transformações Durante uma Pesquisa de Campo. Revista de Administração Contemporânea (RAC), Curitiba, v. 15, n. 2, art. 3, p. 209-227, Mar./Abr, 2011.

[78] TURETA, C.; ARAÚJO, B. F. V. B. de. Escolas de samba: trajetória, contradições e contribuições para os estudos organizacionais. Organizações \& Sociedade, v. 20, n. 64, p. 111-129, 2013.

[79] TURETA, C.; LIMA, J. B. de. Estratégia como Prática Social: o Estrategizar em uma Rede Inter organizacional. Revista de Administração do Mackenzie, v. 12, n. 6. p. 76-108, 2011.

[80] VAARA, E.; WHITTINGTON, R. Strategy-as-practice: taking social practices seriously. The Academy of Management Annals, v. 6, n. 1, p. 285-336, 2012.

[81] VERGARA, S. C.; MORAES, C. M.; PALMEIRA, P. L. A cultura brasileira revelada no barracão de uma escola de samba: o caso da família Imperatriz. In: MOTTA, F. C. P.; CALDAS, M. P. (Org.) Cultura organizacional e cultura brasileira. São Paulo: Atlas, 1997. p. 239-253.

[82] VIVA SAMBA (2015). Disponível em: http://www.vivasamba.com.br. Acesso em: 15 jul. 2015.

[83] WEICK, K. The social psychology of organizing. Reading: Addison-Wesley, 1979.

[84] WHITTINGTON, R. Strategy as Practice. Long Range Planning, v. 29, n. 5, p. 731- 735, 1996.

[85] _. O que é Estratégia?. São Paulo: Pioneira Thomson Learning, 2002.

[86] _. Completing the practice turn in strategy research. Organization Studies, v. 27, n. 5, p. 613-634, 2006.

[87] _. Strategy practice and strategy process: family differences and the sociological eye. Organization Studies, v. 28, n. 10, p. 1575-1586, 2007.

[88] _. Giddens, Structuration Theory and Strategy as Practice. In: Golsorkhi D., ROULEAU L.; SEIDL D.; VAARA, E. (Eds.). Cambridge Handbook of Strategy As Practice, Cambridge: Cambridge University Press, 2010. 
[89] . The practice turn in organization research: Towards a disciplined transdisciplinarity. Accounting Organization and Society, v. 36, n. 3, p. 183-186, 2011.

[90] WHITTINGTON, R.; CAILLUET, L. The crafts of strategy: Introductions to special issue. Long Range Planning, v. 41, n. 3, p. 241-247, 2008.

[91] WILSON, D. C.; JARZABKOWSKI, P. Thinking and acting strategically: New challenges for interrogating strategy. European Management Review, v. 1, n. 1, p. 14-20, 2004.

[92] YANOW, D. Organizational ethnography between toolbox and world-making. Journal of Organizational Ethnography, vol. 1, n. 1, 2012. 


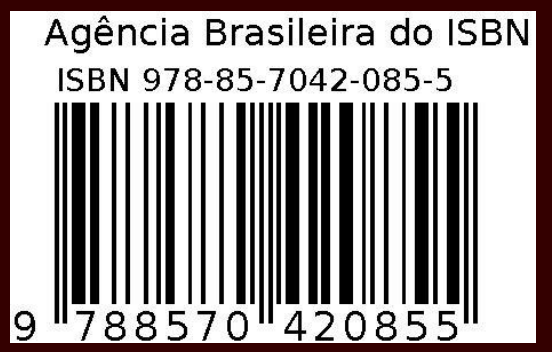

